بسم الله الرحمن الرحيم

\title{
بمث بمنتوان
}

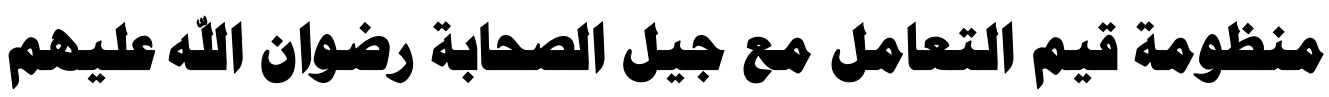

$$
\text { كما جاءت في الكتاب والسنة }
$$

The system of values for dealing with the generation of companions (may Allah be pleased with them) as stated in the Quran and Sunnah

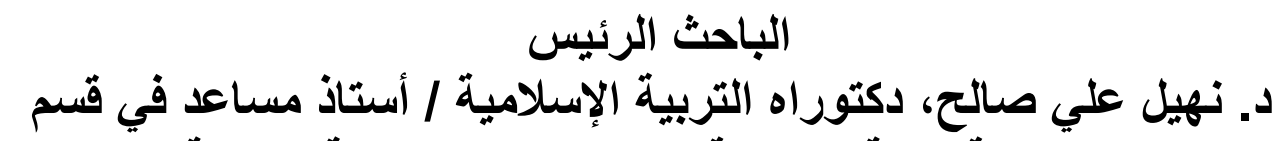

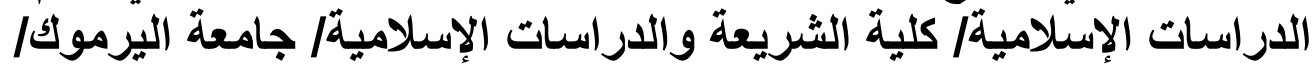
الأردن

الباحث المشارك

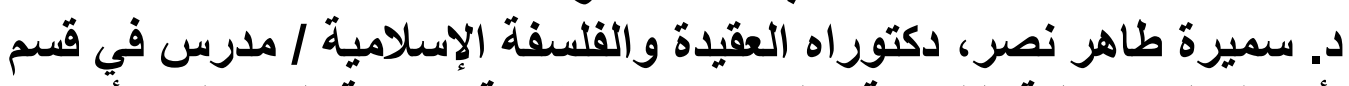

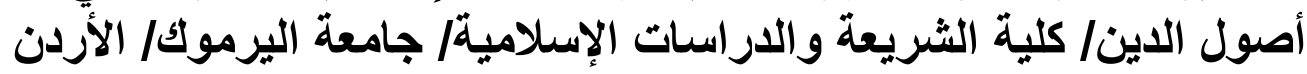


$-\leqslant 17$. 


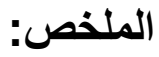

هدف هذا البحث إلى تحديد منظومة قيم التعامل مع جيل الصحابة رضوان الله عليهم كما جاعت في الكتاب والسنة، التي تعمل على ضبط طريقة التعامل مع سير ذلك الجيل الفريد، عن طريق تقصي أكبر عدد ممكن من القيم الخاصة بالتعامل مع جيل الصحابة والتي تليق بمقامهم الكريم ورفعة شأنهم، إذ ببيانها وغرسها في الجيل الجديد تعزيز لمكانة أفضل القدوات بعد الأنبياء في النفوس، وتأكيا على مكانتهم وفضلهم على سائر الأجيال اللاحقة، وإسهام في تكوين درع قوي لصد الهجمات الغابرة عليهم، وقد استند هذا البحث على المنهج الاستقرائي التحليلي، وذلك باستثراء منهج التعامل مع سير الصحابة في القرآن الكريم والسنة النبوية ونماذج من أقوال العلماء في التراث الإسلامي. وقد أظهرت النتائج أن منظومة قيم التعامل مع جيل الصحابة -رضوان الله عليهمهي المعايير والمرتكزات الخاصة بالتعامل مع جيل الصحابة والتي تعد منهجية فكرية تحدد طبيعة فهم وقراعة سيرهم العطرة والتي تتناسب مع رفعة شأنهم ومقامهم الكريم، فمن توقيره وبره ـصلى الله عليه وسلم- توقير أصحابه وبرهم ومعرفة حقوقهم والاقتداء بهم، وحسن الثناء عليهم والاستغفار لهم والإمساك عما شجر بينهم ومعاداة من عاداهم، التي جاءت شواهدها في القرآن والسنة النبوية.

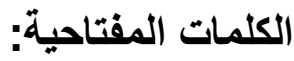
منظومة القيم، الصحابة، الكتاب والسنة 


\section{Abstract:}

The aim of this research is to identify the system of values needed to deal with the generation of companions (may Allah be pleased with them) as stated in the Quran and Sunnah. These Values controls the way that we use in dealing with their history by exploring as many values as possible which are worthy and appropriate to their dignity and prestige. The identification of those values and instilling it in the new generations would end in strengthening those companions whom are the best example models in the souls after the Prophets in addition to emphasize their stature and favor on all later generations. It would be a contribution and input to form a strong shield against different attacks targeting the entire nation. This research was based on the analytical inductive method, by extrapolating the method of dealing with the history of the Companions in the Holy Quran and Sunnah and examples of the scholars' opinions on the Islamic heritage.

The results showed that the system of values of dealing with the generation of companions - may Allah be pleased with them - are the standards and the foundations of dealing with those generation of companions which is considered intellectual nature that determines the nature of understanding and reading their glorious history. It is a fact that part of respecting and honoring Prophet Muhammad, peace be upon him is to honor his companions and realize their rights, follow them, praise them, ask forgiveness for them, stop focusing on differences and disagreements between them and to be hostile against their enemies. These points came in the Holy Quran and Sunnah . Key Words:

Values System, Companions, Quran and Sunnah 


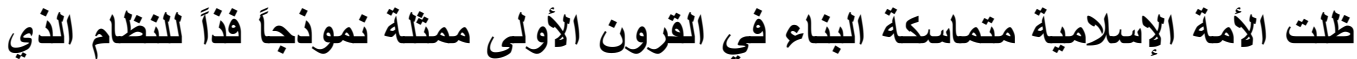

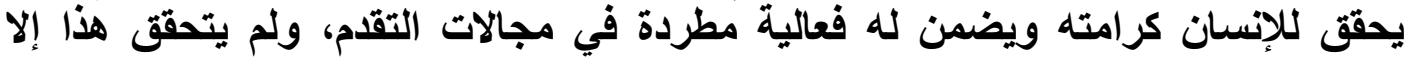

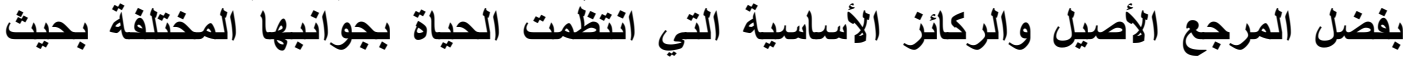

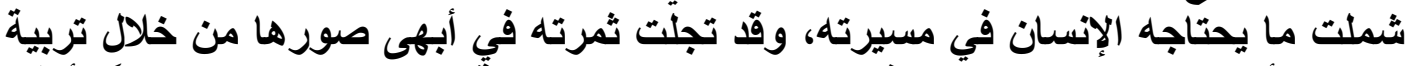

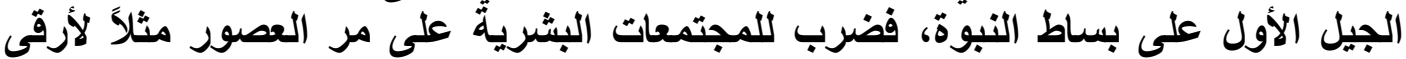

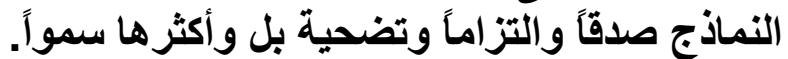

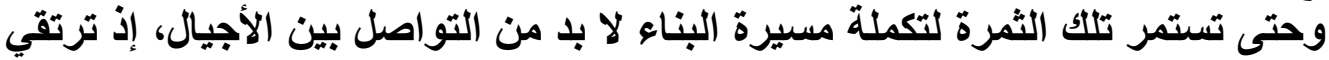

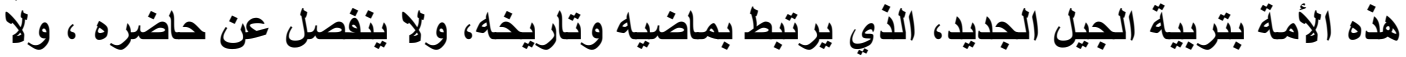

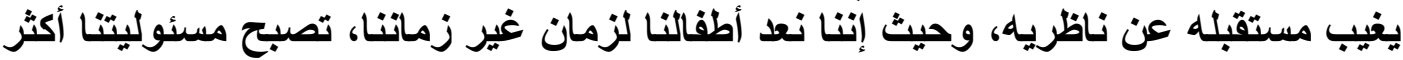

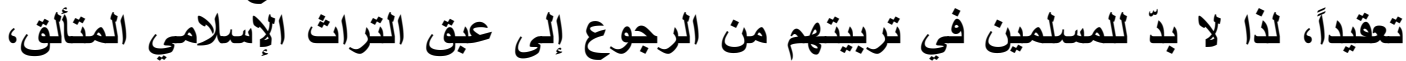

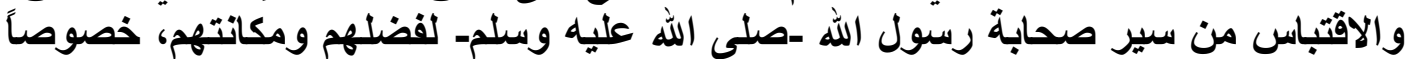
في هذا الزمان الأي كثرت فيه فتن الثبهات وفتن الثهوات، وكثر فيه فيه دعاة الضلال وتثوعت أساليبهم ومناهجهم. ولما كان التصور الأي يحمله الإنسان ونظام القيم المنبئق عنه والأي يستثد إلى القرآن

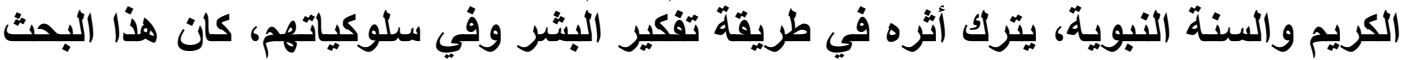

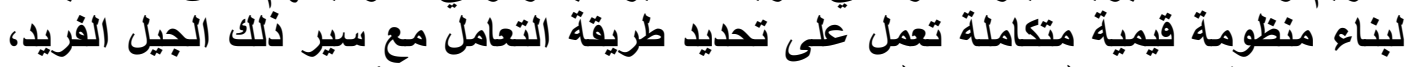

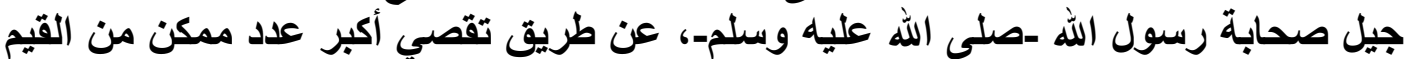

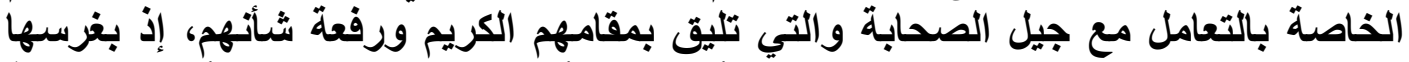

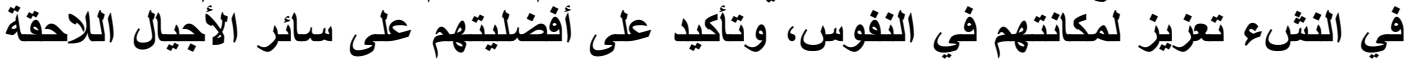

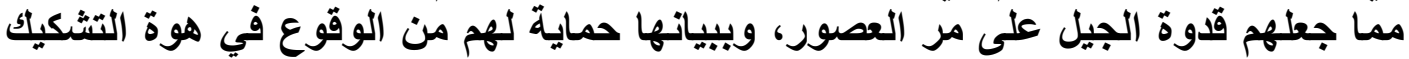

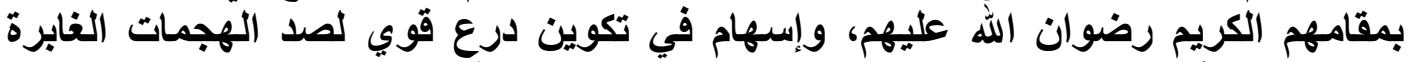

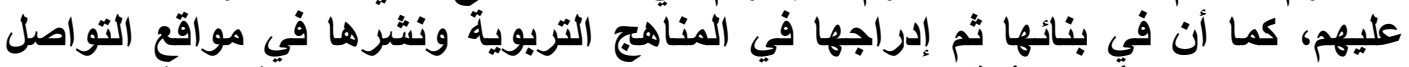

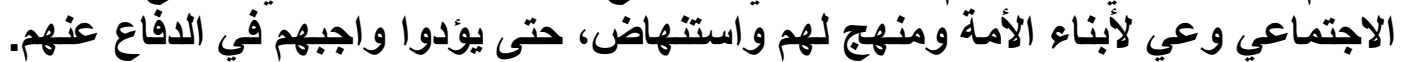
أهداف البحث وتشساؤلاته:

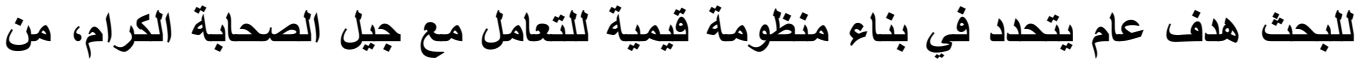

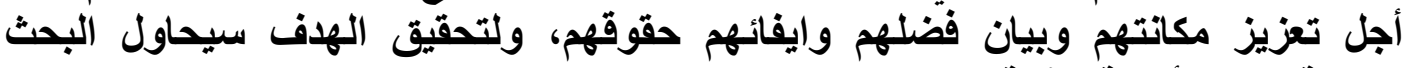
الإجابة على الأسئلة الآتية: ا - - ما مفهوم المنظومة الإنية القية وما أهميتها في التعامل مع جيل الصحابة رضوان الله عليهم? r - ما المنظومة القيمية التي يمكن تحديدها للتعامل مع جيل الصحابة رضوان الله عليهم

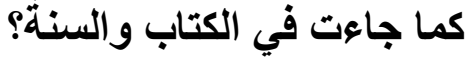
r- ما خصائص منظومة البناب قيم التعامل مع صحابة رسول الله وما تطبيقاتها ؟

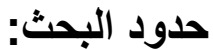

اقتصر البحث على تحديد منظومة قيم التعامل مع جيل الصحابة رضوان التهر الله عليهم كما

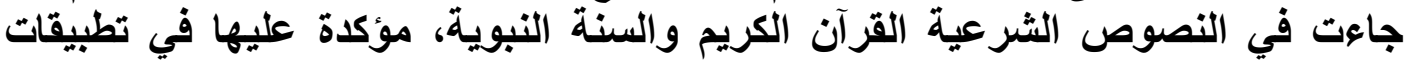

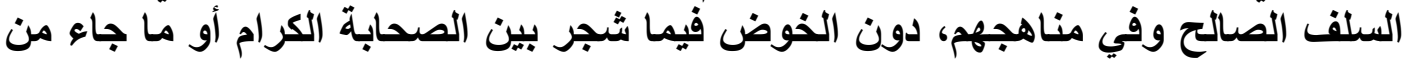


أباطيل الفرق الضالة بحقهم رضي الله عنهم وأرضاهم أجمعين، منعاً للتطويل، وحرصاً

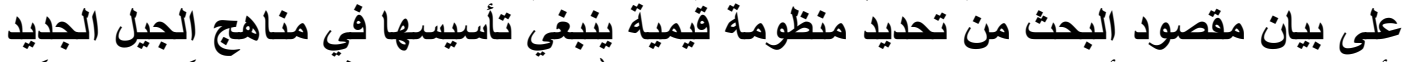

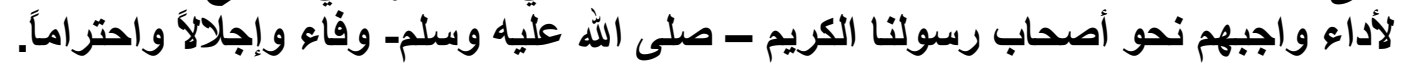

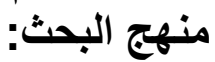

يستند هذا البحث على المنهج الاستقرائي التحليلي حيث ستقوم الباحثة باستقراء طريقة

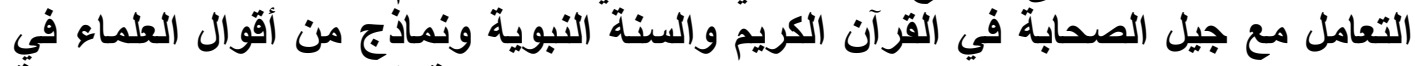

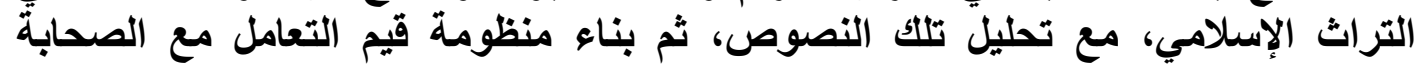

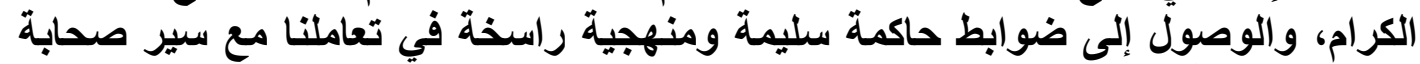

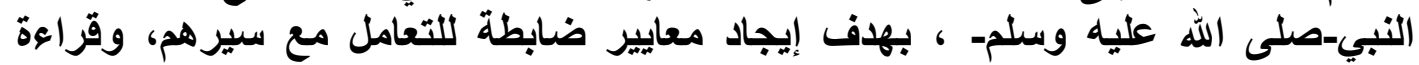

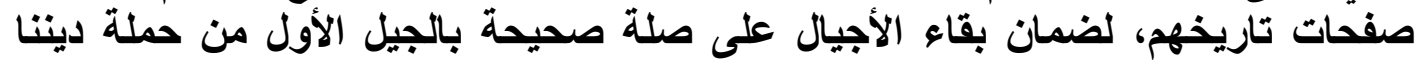
خطة البحث: لقد جاعت خطة البحث مثتملة على مقدمة وثلاثنة مباحث، فتناول المبحث الأول مفهوم

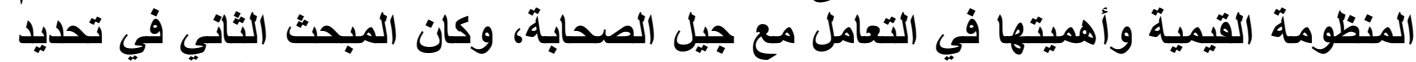

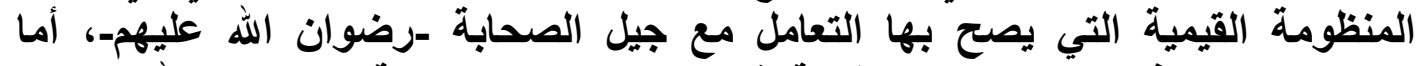

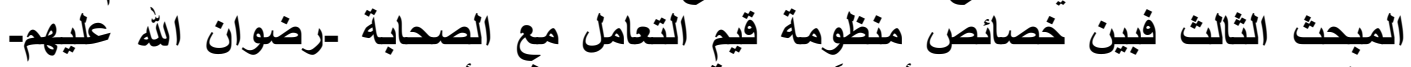

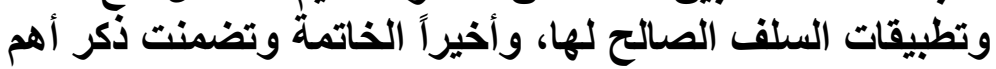

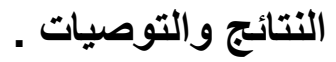




\section{المبحث الأول}

\section{هفهوم المنظومة القيمية وأهميتها في التعامل مع جيل الصمابة رضوان}

\section{pasto dill \\ J المطآب}

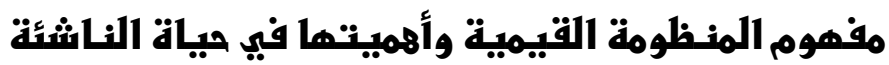

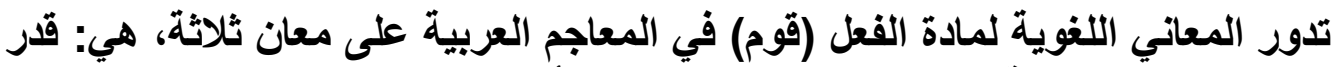

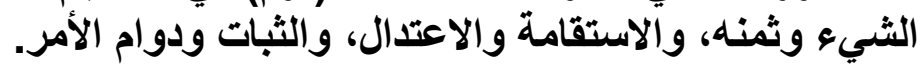

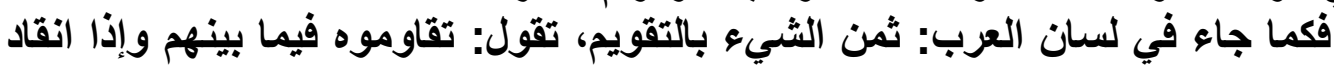

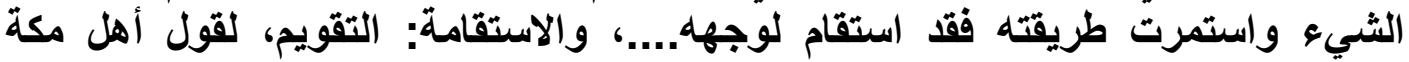

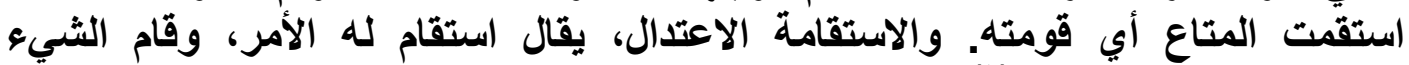

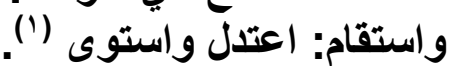

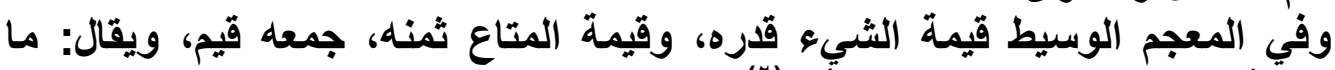

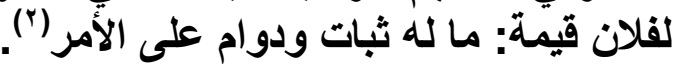

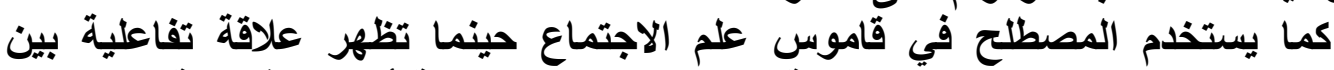

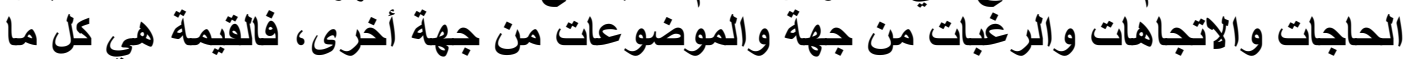

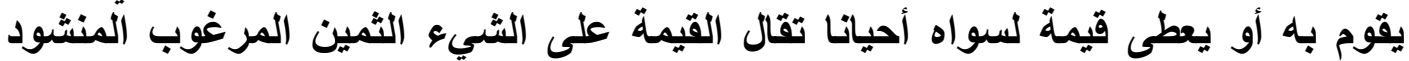

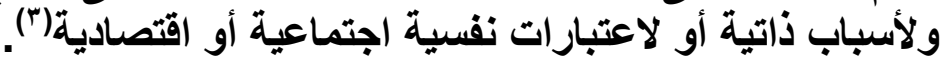

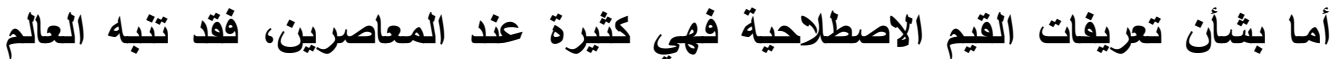

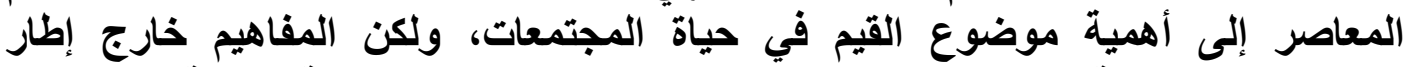

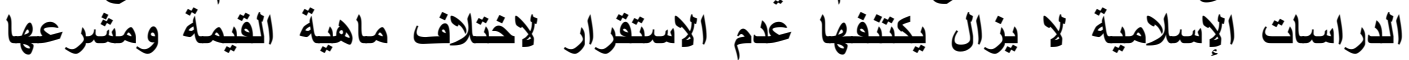

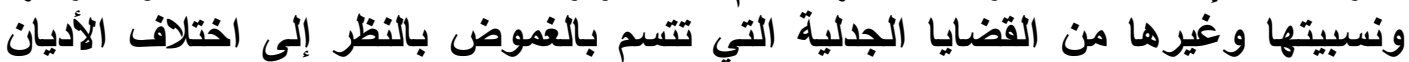

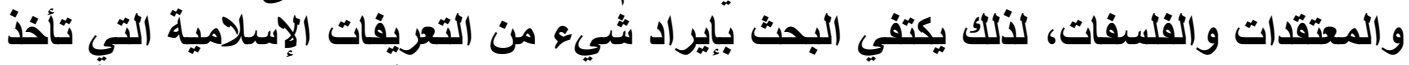

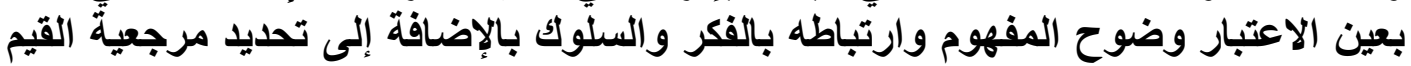
ومصدر ها، ومن ذلكئ

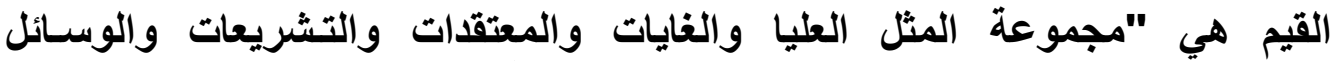

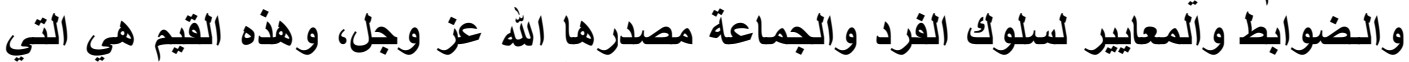

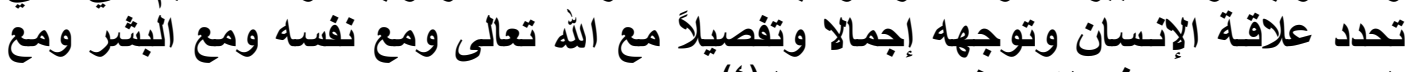

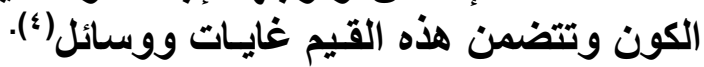

(') ابن منظور، محمد بن مكرم بن على، أبو الفضل، جمـال الدين ابن منظور الأنصاري، لسان العرب،

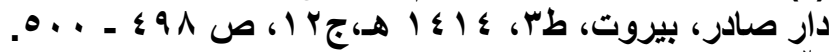

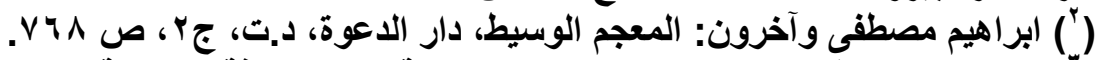

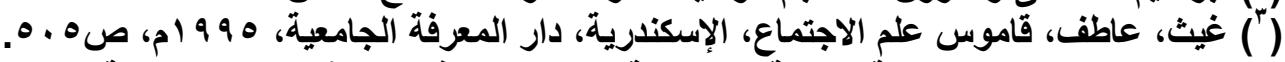

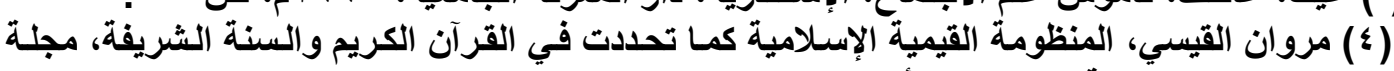

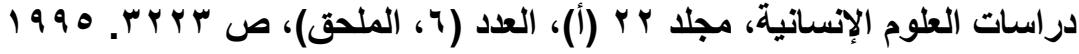


أو " تلك المفاهيم والمعاني التي يولد الإنسان بموجبها ولادة ربانية، ويعيش في ظلال

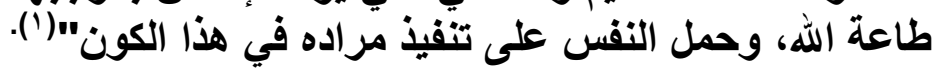

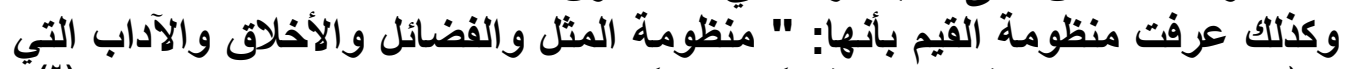

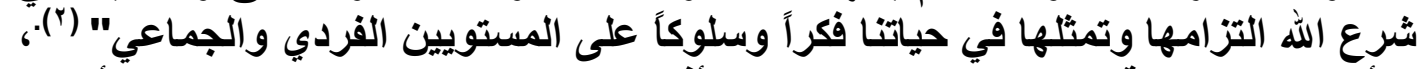

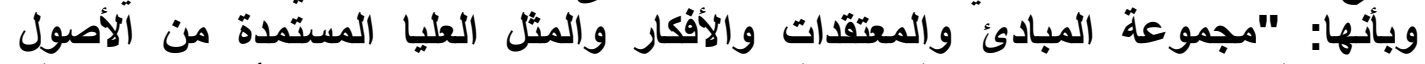

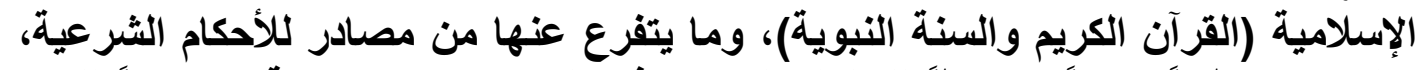

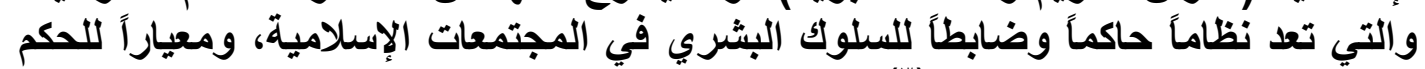

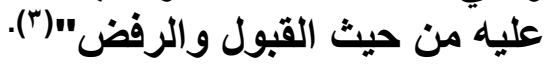

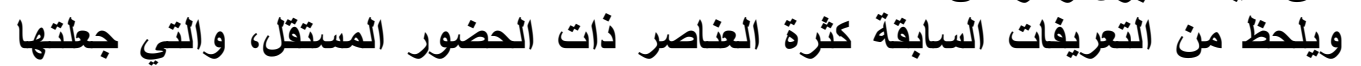

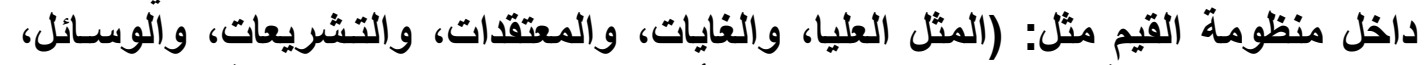

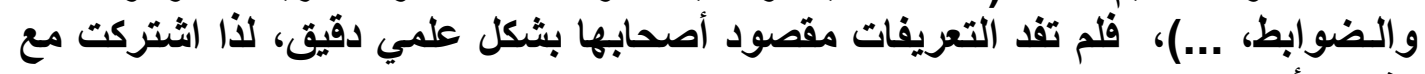
ولكنتا نجد فيها تأكيا على المنظومة والمجموعة لعدد من القيم، ويلحظ أنها ترتكز

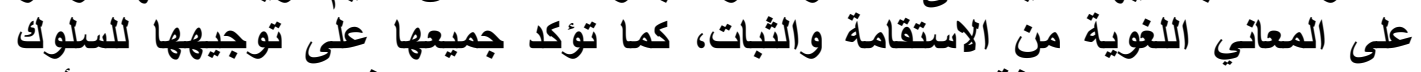

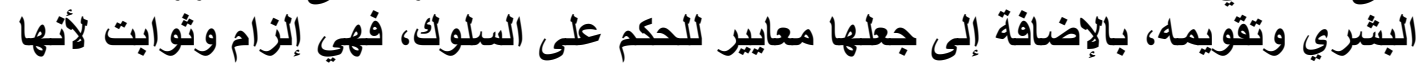
وهو أمر يوصل إلى الأركان الواجب توافرها في التعريف، وعليه فيمكن تحديد أركان

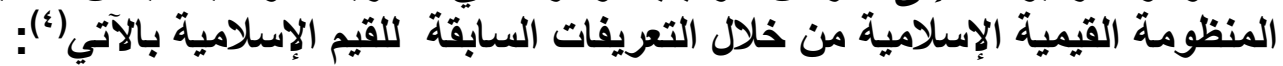

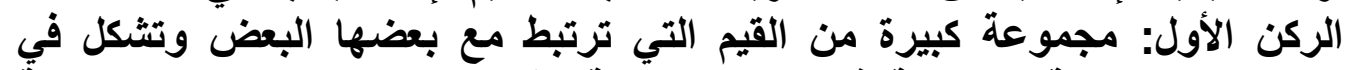

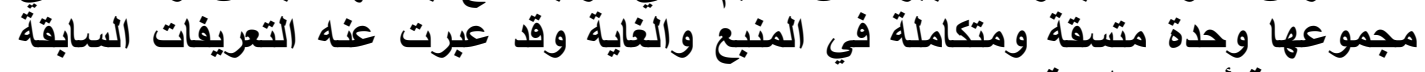

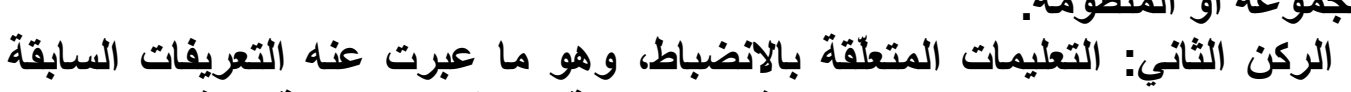

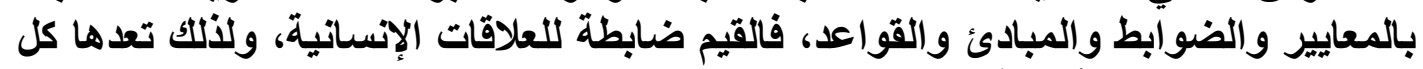

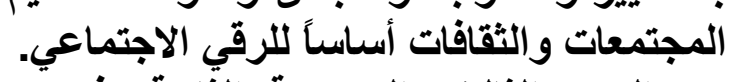

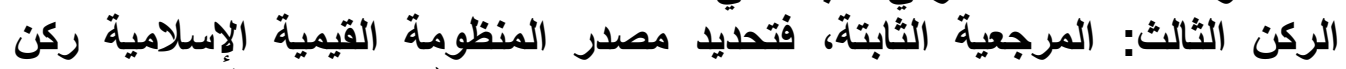

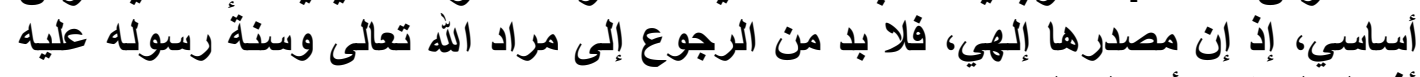

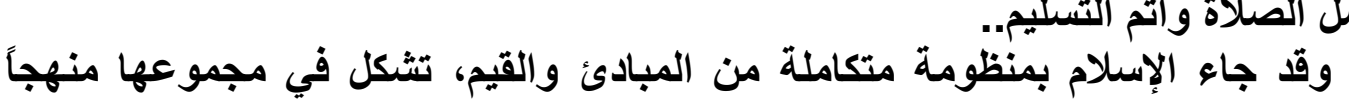

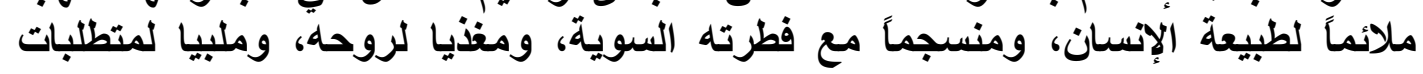

(1) مسعود،، عبد المجيد، القيم الإسـلامية التربويـة والمجتمع المعاصر، كتـاب الأمةــوزارة الأوقـاف

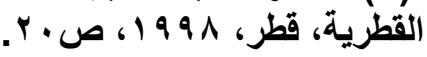

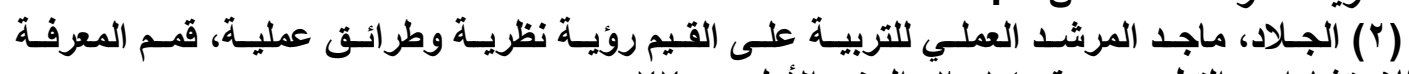

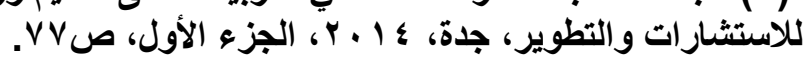

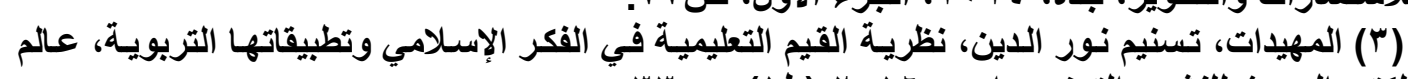

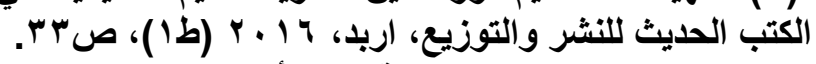

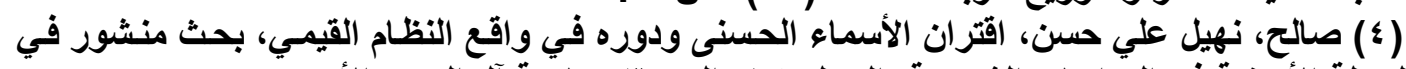

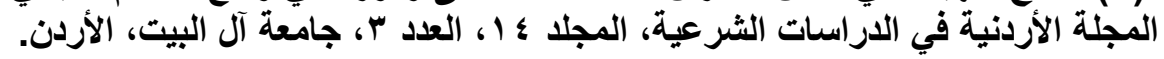


الحياة الإنسانية الكريمة، وهي منظومة محكمة النسيج، مترابطة الحلقات، تقوم على أركان

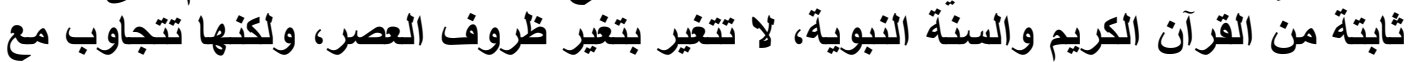

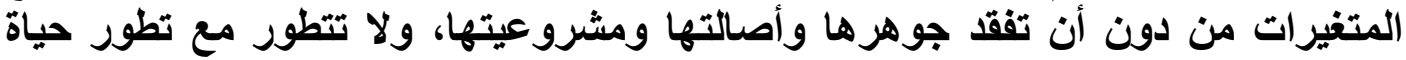

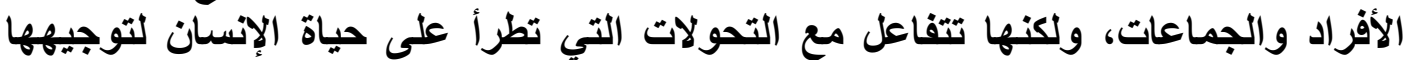
نحو الأفضل وترشيد مسار ها (') ويناء على ما تقلم يمكن تعريف المنظومة القيمية: بأنها تلك المعايير التي استقرت

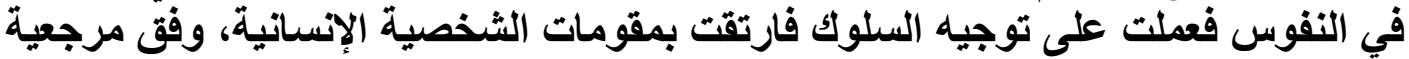

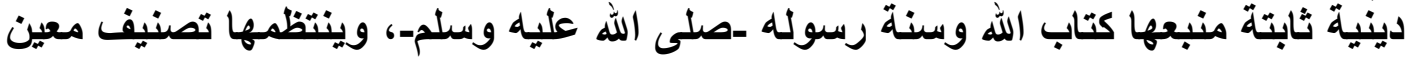
بهدف الوصول إلى سعادة الدارين.

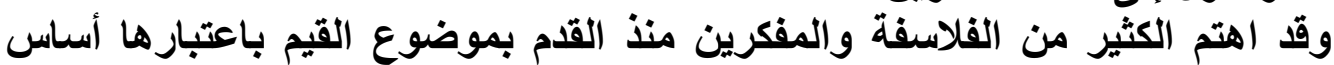

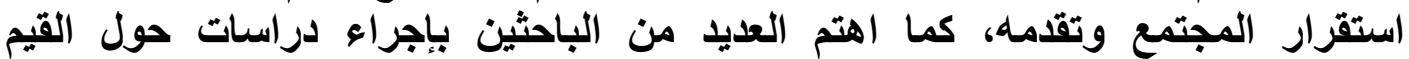

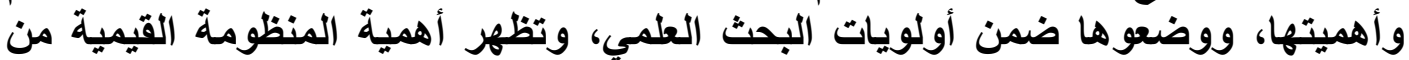

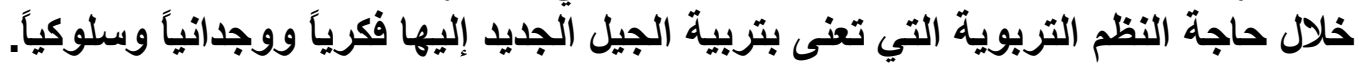

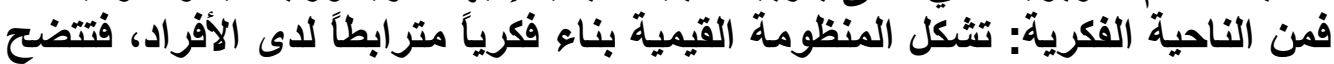

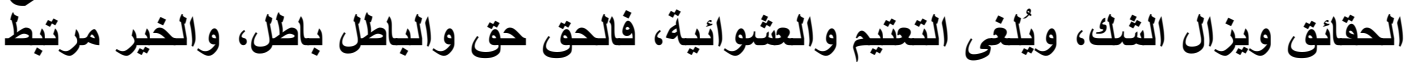

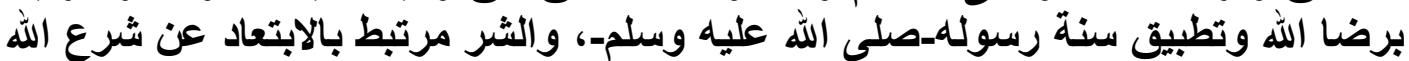

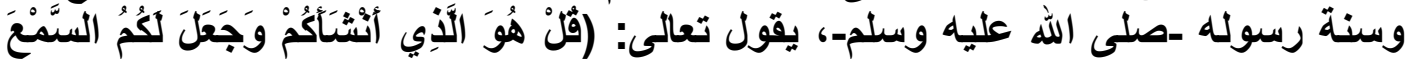

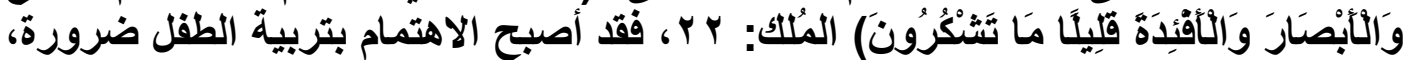

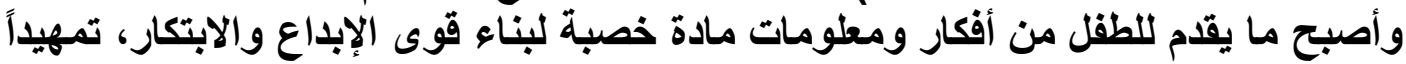

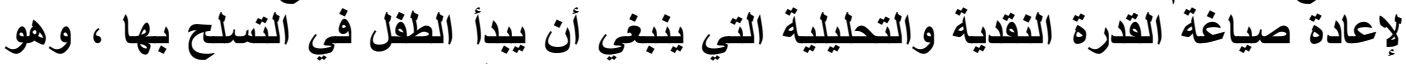

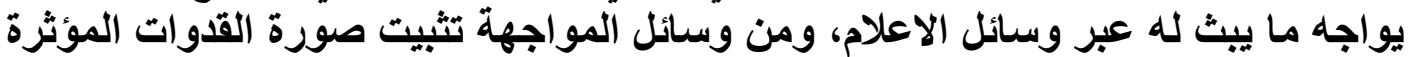

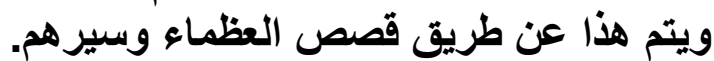

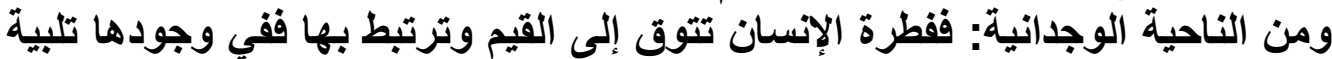

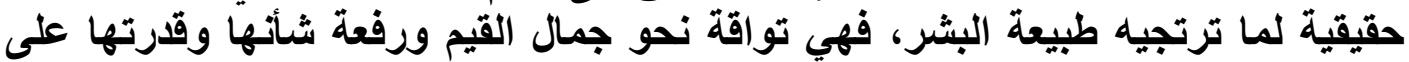

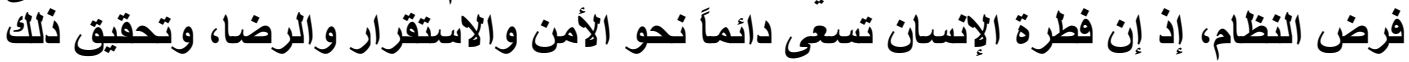

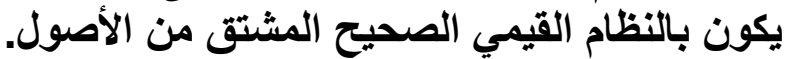

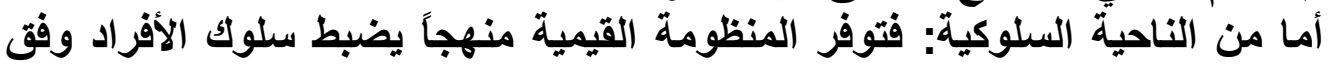

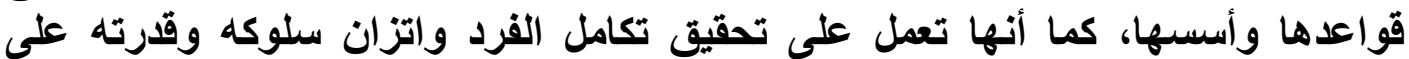

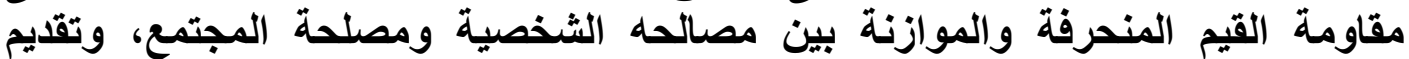

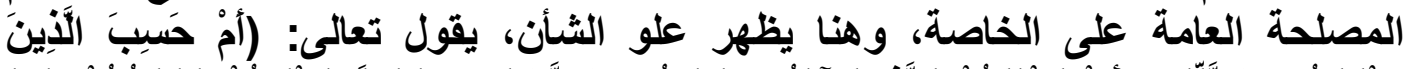

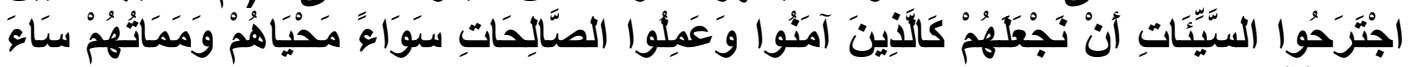

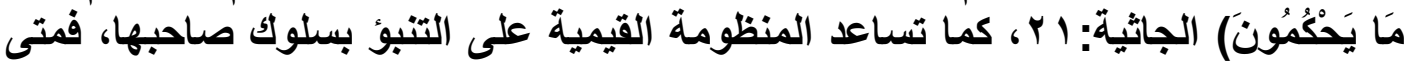

(1) الكتاني، محمد، منظومـة القيم المرجعيـة في الإسـلام، المغرب، دار أبـي رقراق للطباعة والنشر،

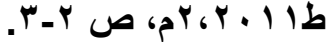


عرفنا ما لاى الفرد من قيم استطعنا أن نتنبأ بما سيكون عليه سلوكه في المواقف وائف

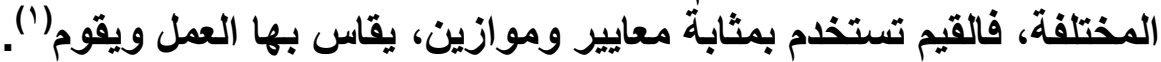

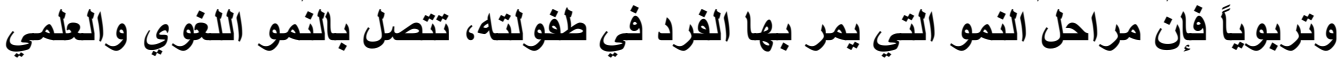

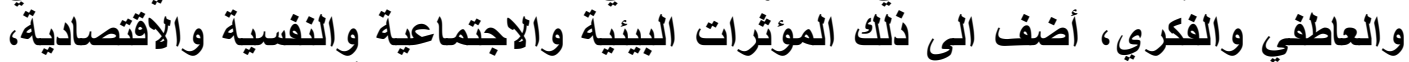

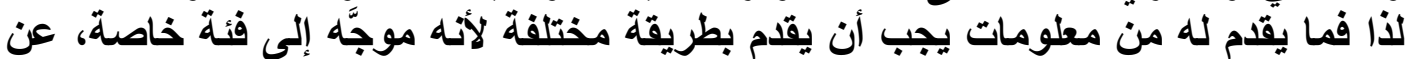

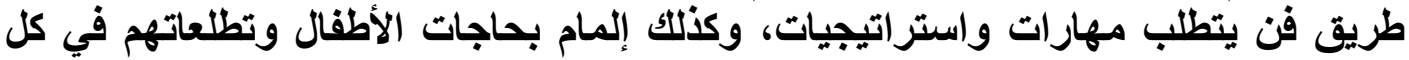

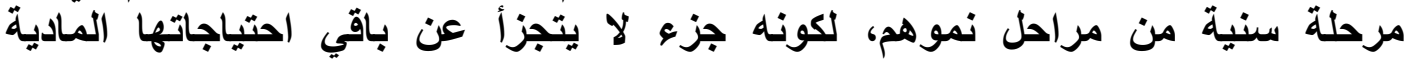

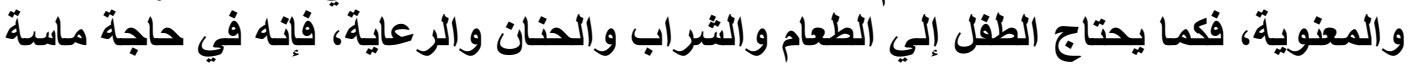

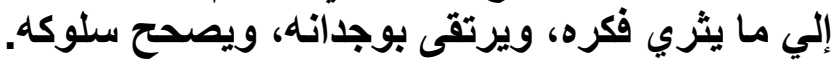

\section{المطلب النثانيى}

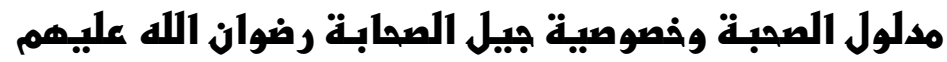

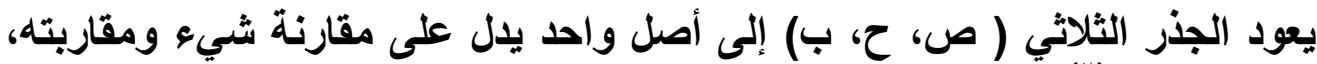

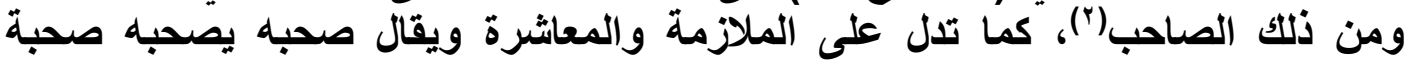

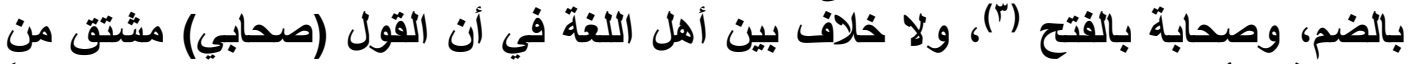

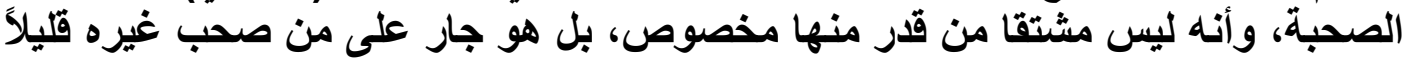

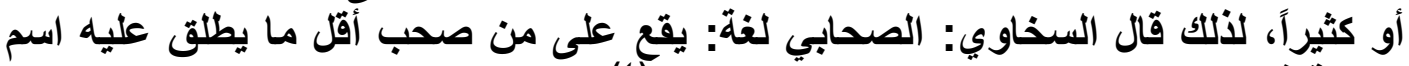

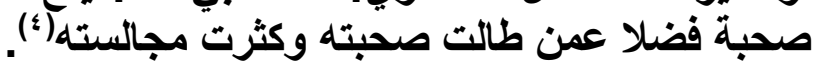

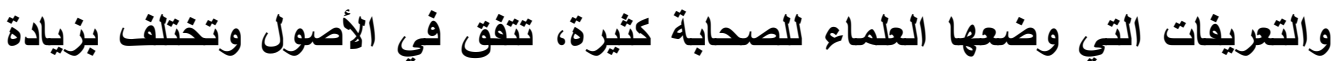

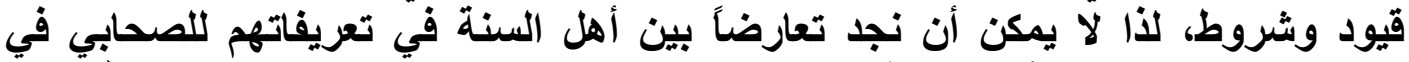

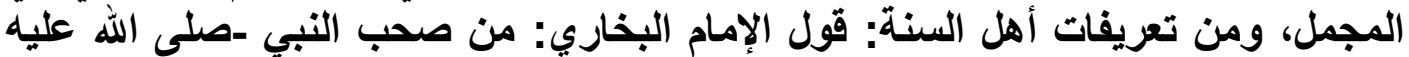

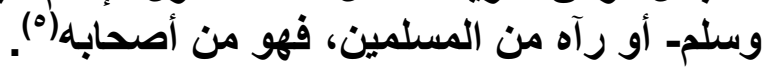

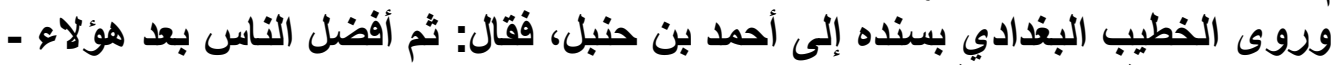

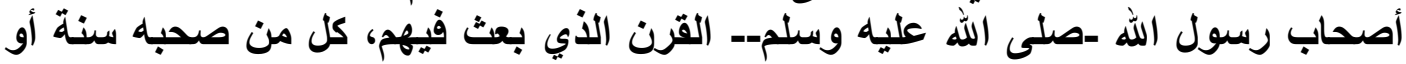

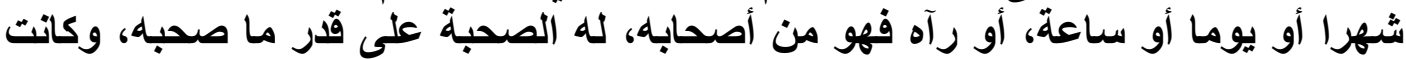
سابقته معه، وسمع منه ونظر إليه(")

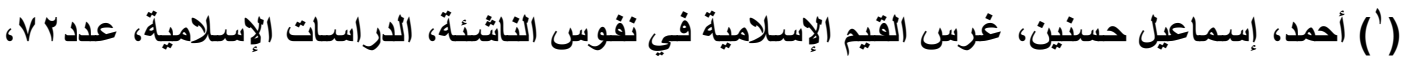

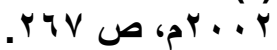

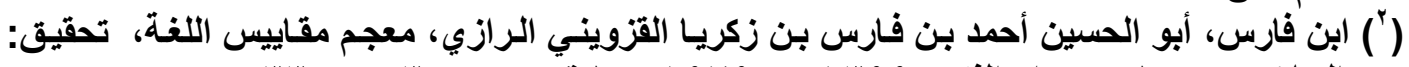

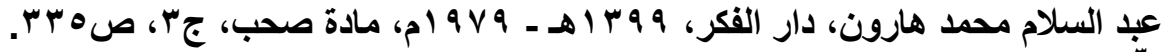

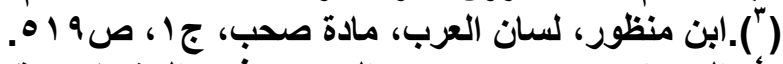

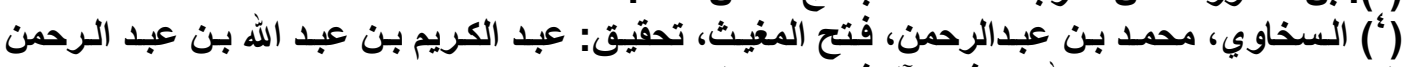

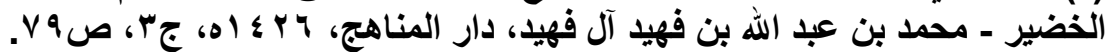

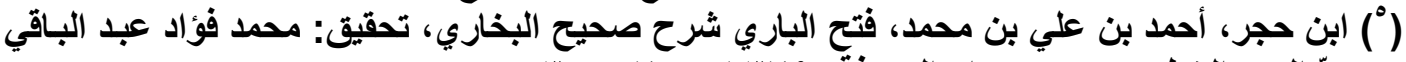

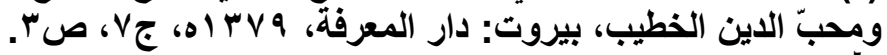


ولكن التعريف الأي اعتمدته أكثر الاراسات هو ما قرره الحافظ ابن حجر بقوله:

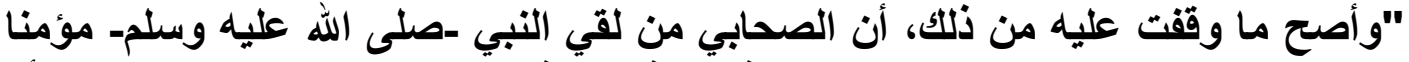

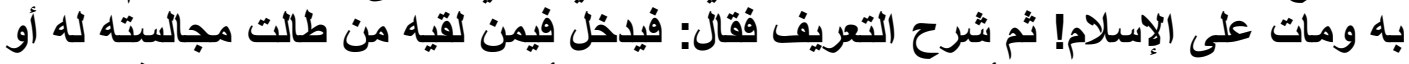

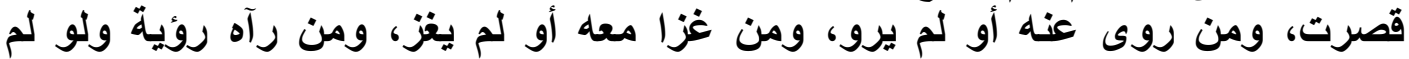

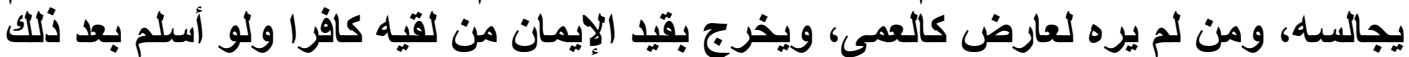

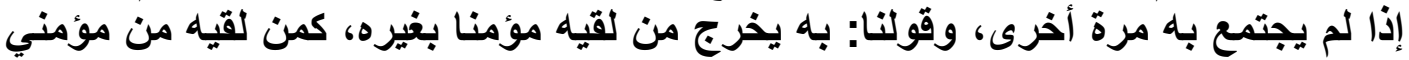

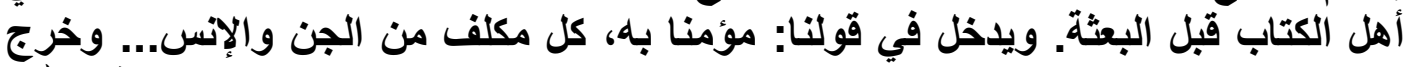

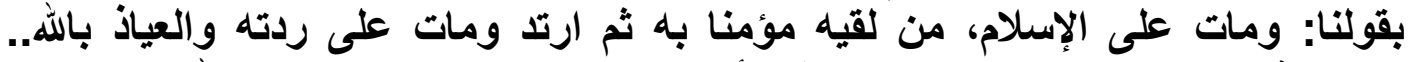

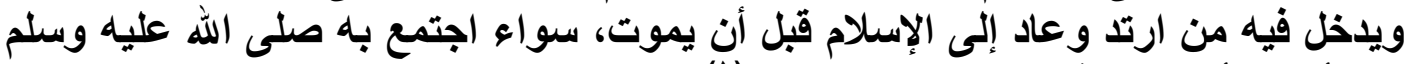

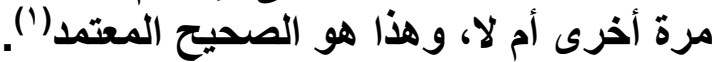

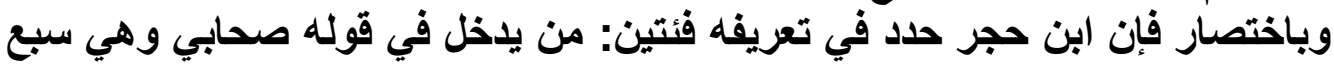

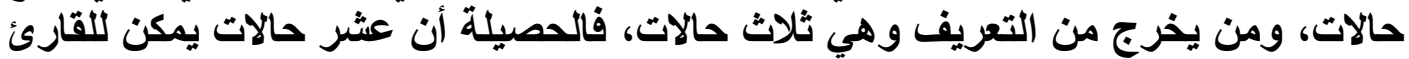

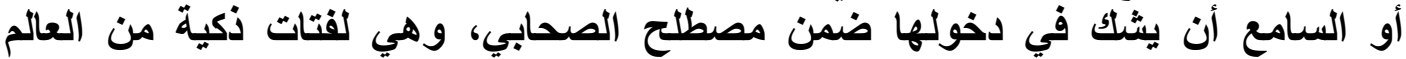

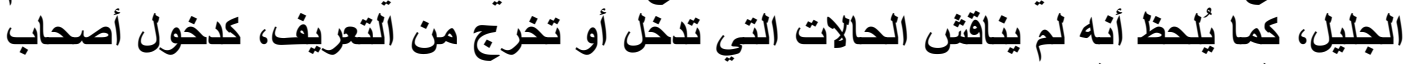

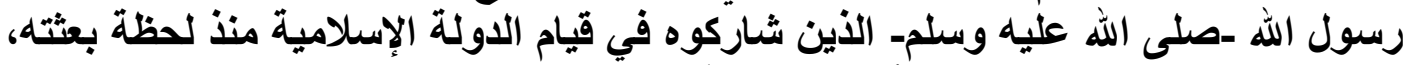

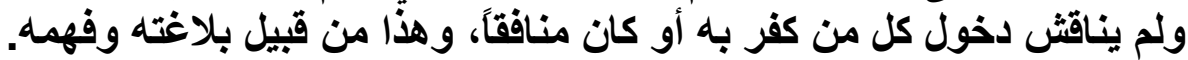

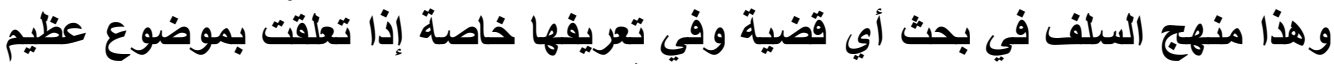

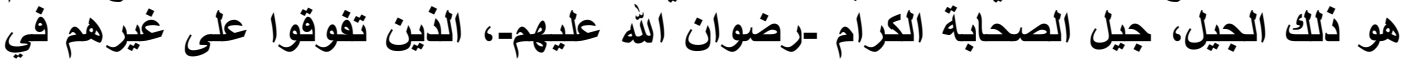

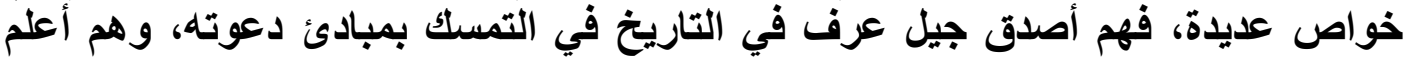
جيل عرف في التاريخ في الإدراك لأصول ما آمن بهاه، وتأتي خصوصية فيل فيل الصحابة من دهن

أولاهما: صدق الاعتقاد والتمسك بالاعوة والتضحية بكل ما يملكون في سبيل قيامها

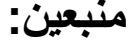
ونشرها.

ثانيهما: قوة العلم والفهم لتعاليم الاعوة، فهم جيلها الأول والمعايشين لمؤسسها -

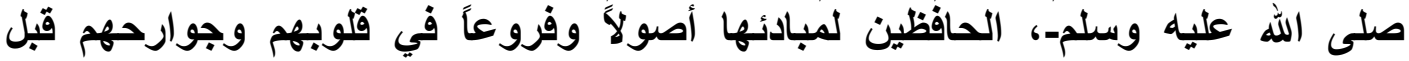
عقولهم. لذلك حازوا قصبات السبق وارتقوا أعلى المعالي، وفي تأكيا هذا التفوق يقول التبي

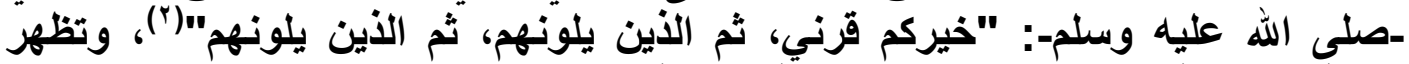

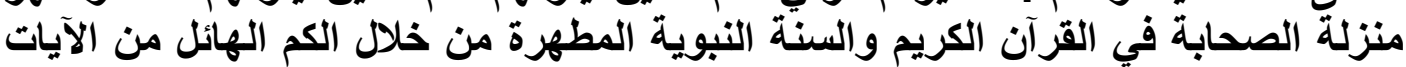

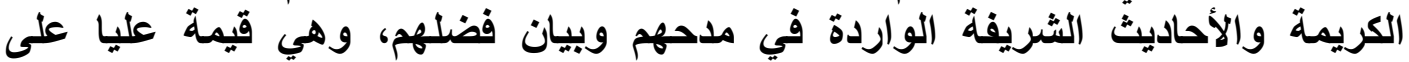

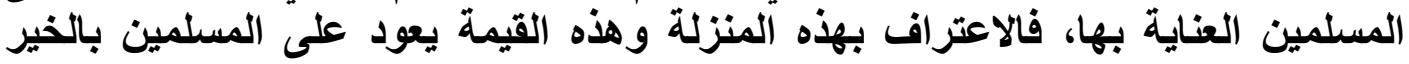

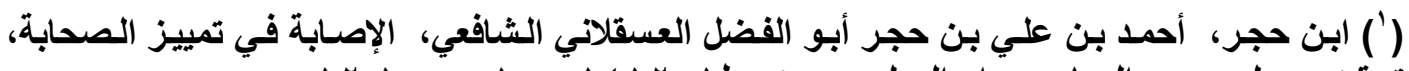

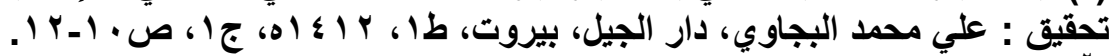

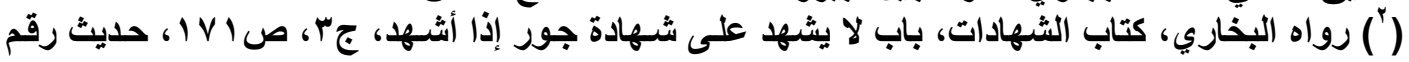


والنفع بسبب تطبيقهم لمراد الله ووجود الأنموذج الأمثل بعد رسول الله ـصلى الله عليه

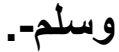

\section{المطll}

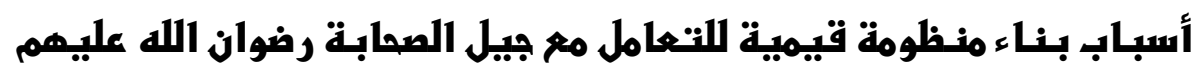

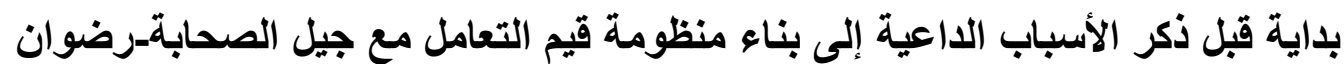

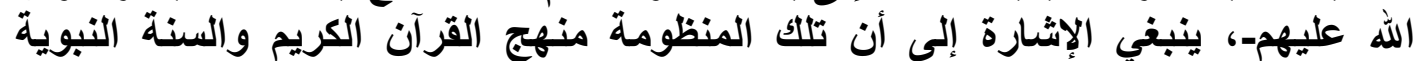

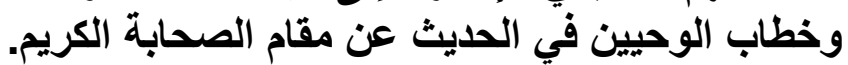

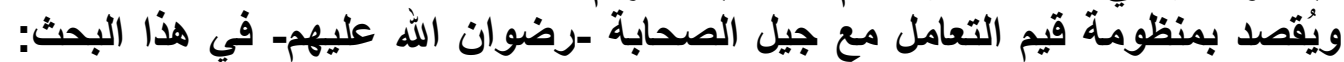

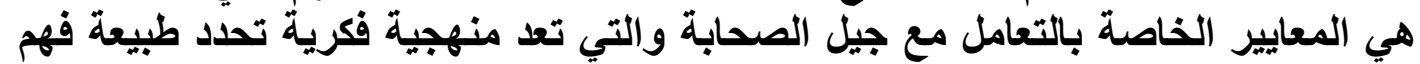

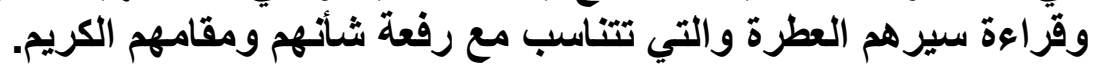

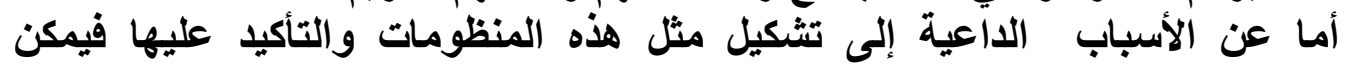
تلخيصها بالآتي: • أولى أسباب البناء يلخصها القاضي عياض بقوله: "ومن توقيره وبره -صلى الله عليه

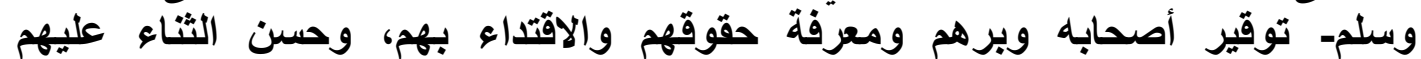

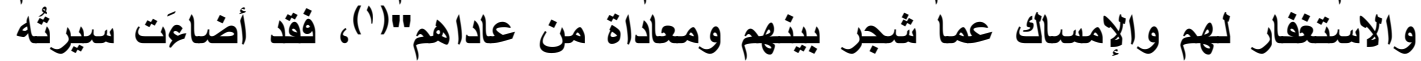

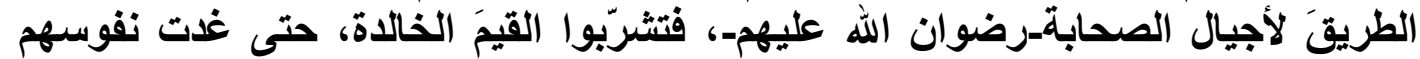

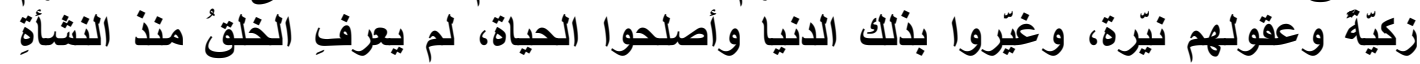

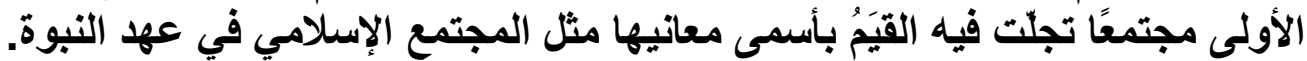

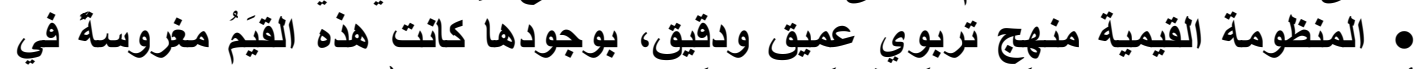

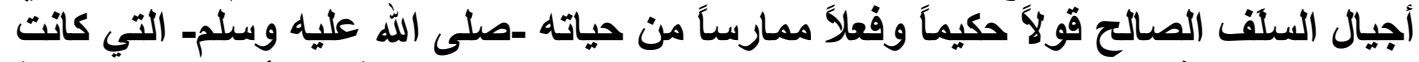

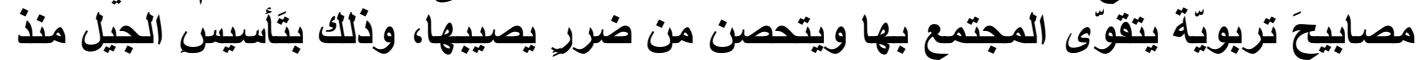

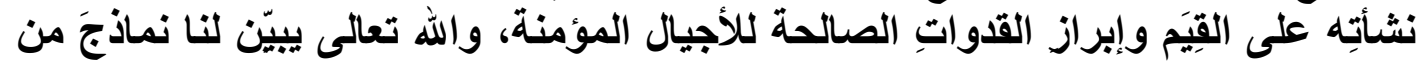

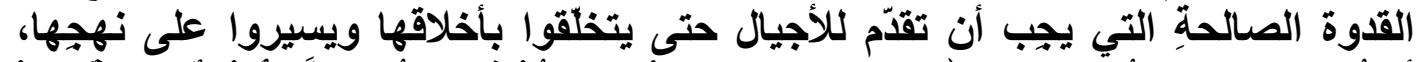

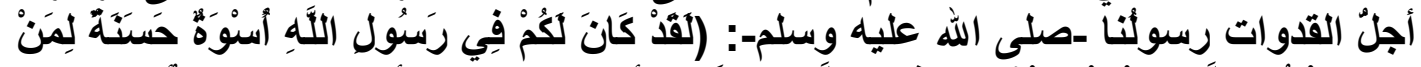

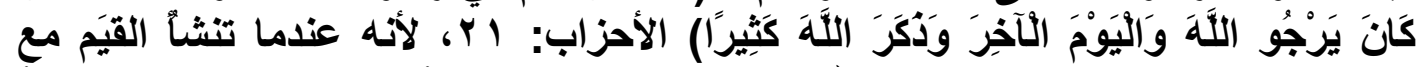

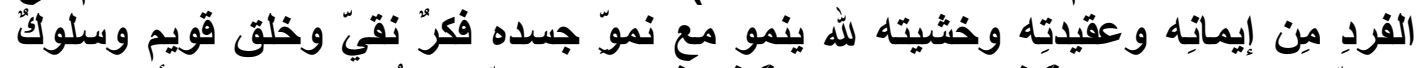

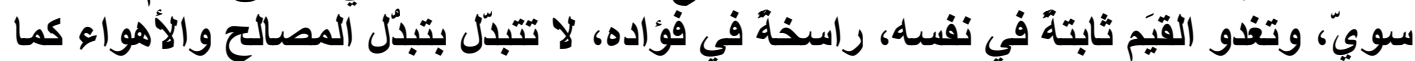

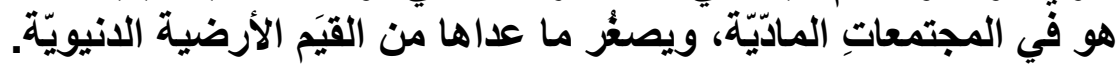

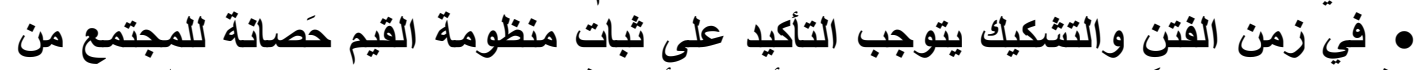

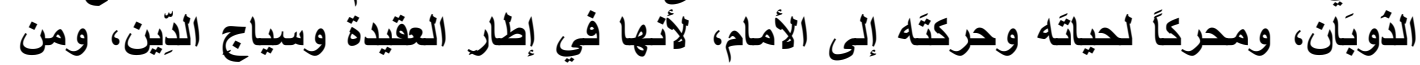

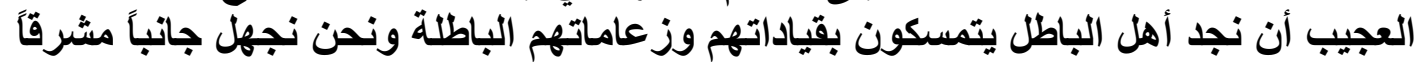

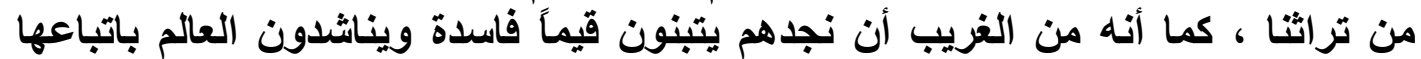

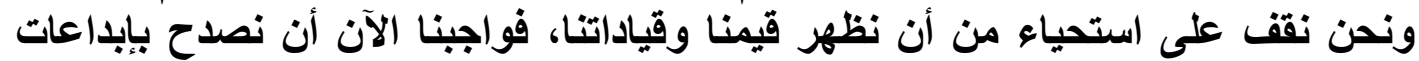

(') القاضي عياض، أبو الفضل القاضي عياض بن موسى، الشفا بتعريف حقوق المصطفى، دار الفكر

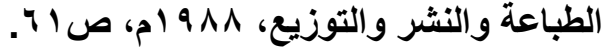


صحابتنا الكرام، وأن نؤطر منهجاً واضحاً للتأدب في ذكرهم واجلال أفضالهم علينا وعلى

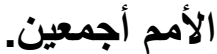

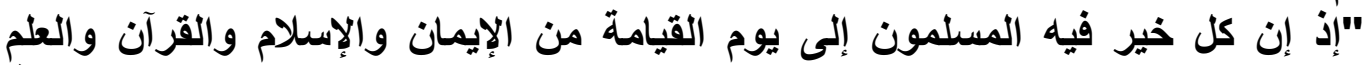

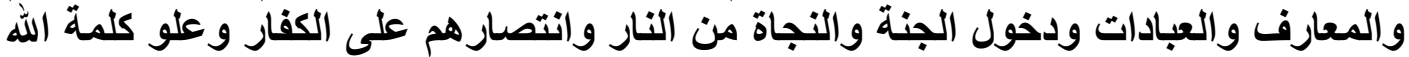

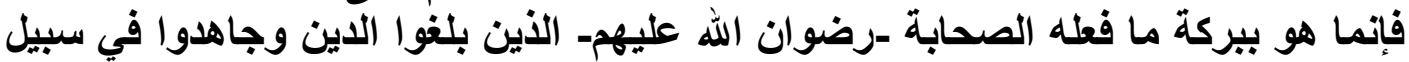

وأما عن طريقة تنظيم القيم الواردة في المنظومة فيمكن تلخيصها في النقاط الآتية:

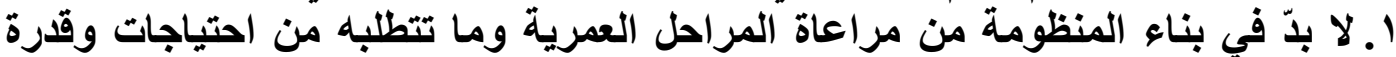

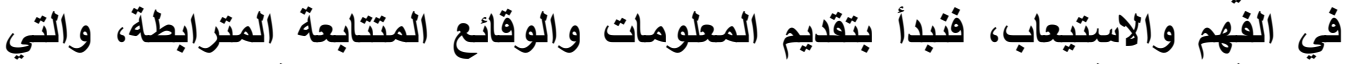

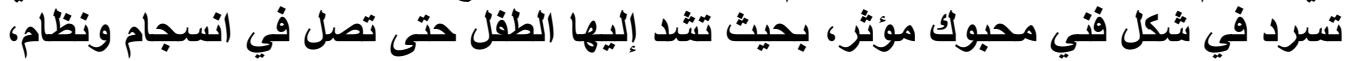

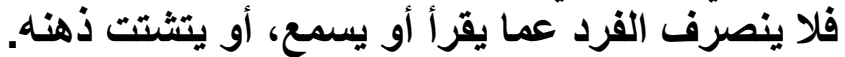

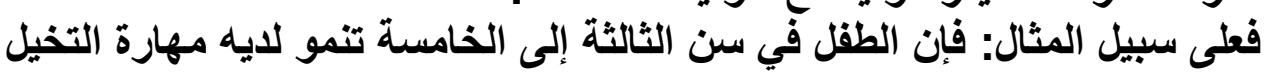

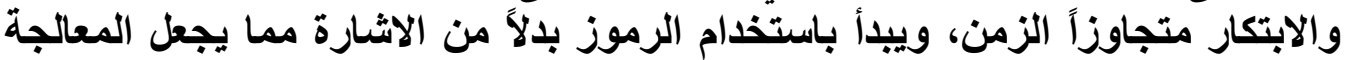

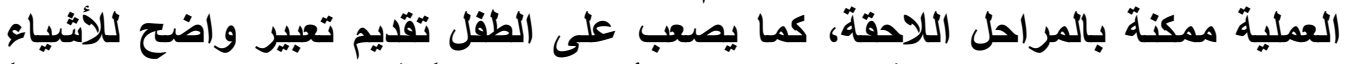

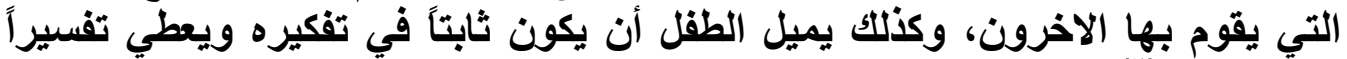

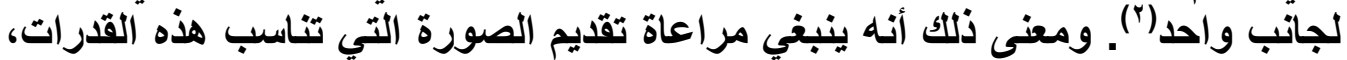

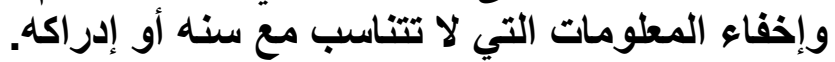

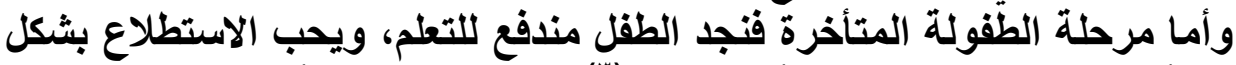

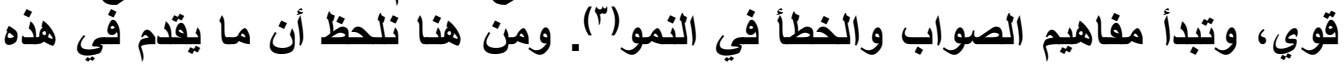

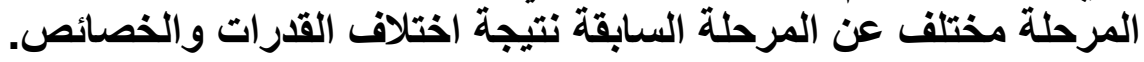

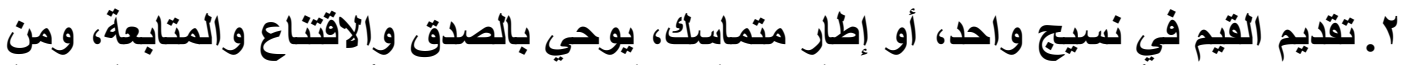

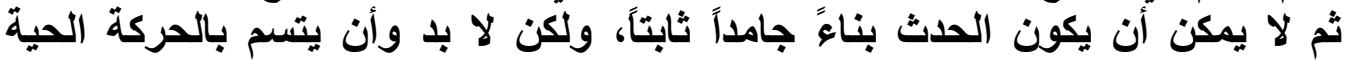

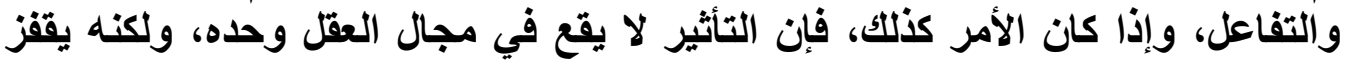

$$
\text { إلى الوجدان والنفس. }
$$

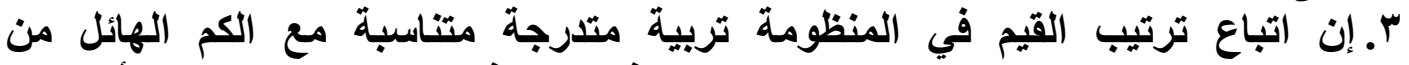

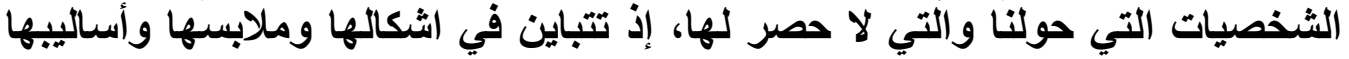

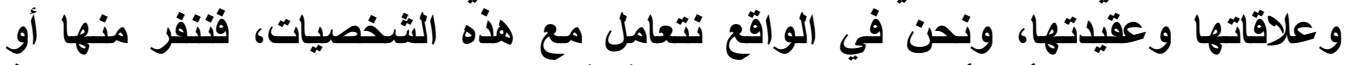

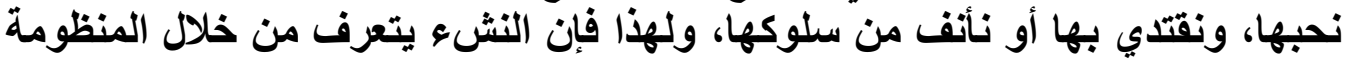

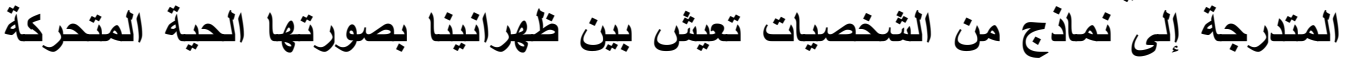

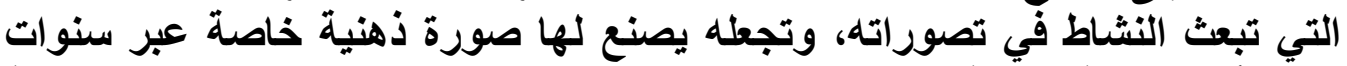

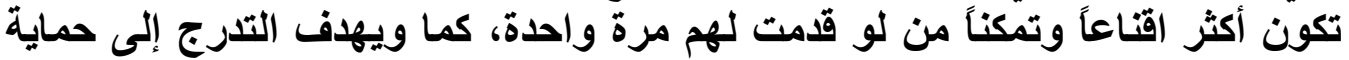

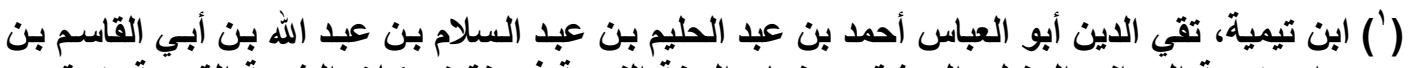

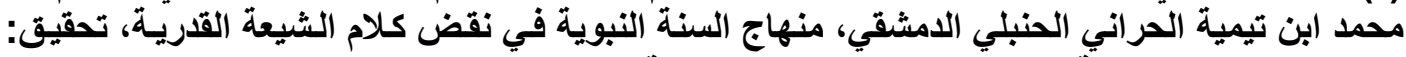

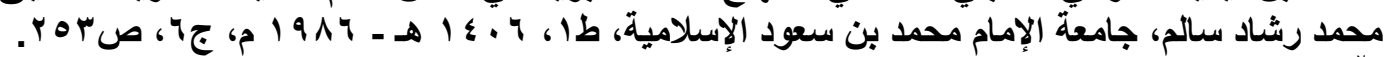

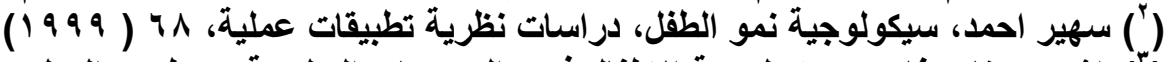

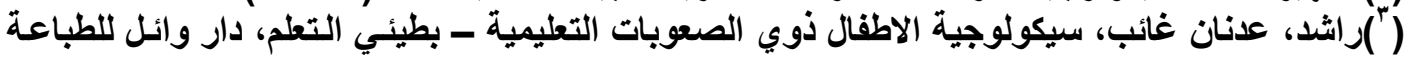

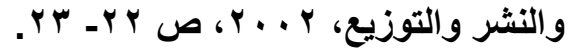




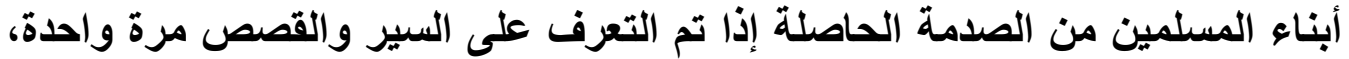

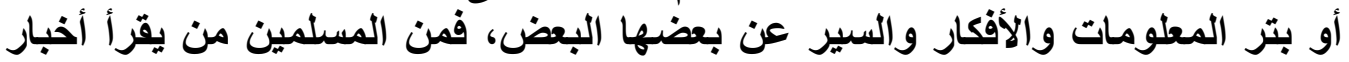

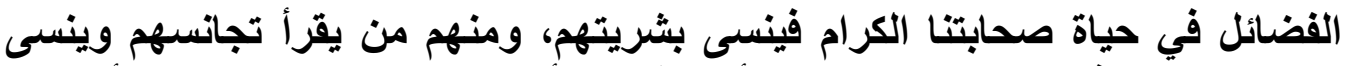

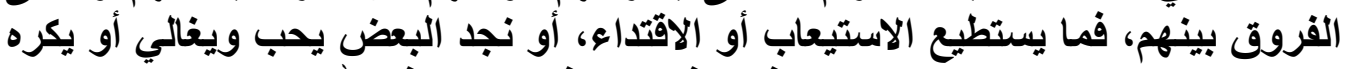
ويسب ويشتم بغير وعي ولا إدراك، فيقع في المحذور والعياذ بالله.

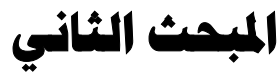

\section{تمديد المنظومة القيمية التي يمح بها التعامل مع جيل المصابة -رضوان}

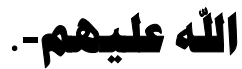

بنى القرآن الكريم والسنة النبوية منظومته القيمية للتعامل مع جيل الصحابة -رضوان

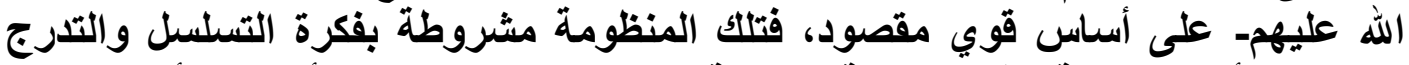

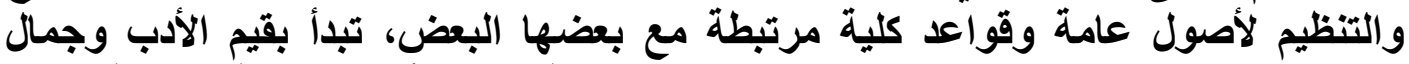

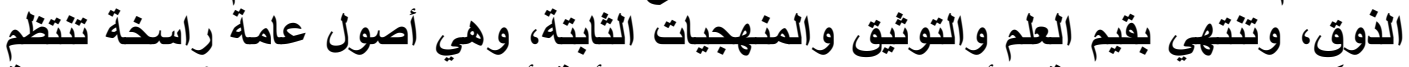

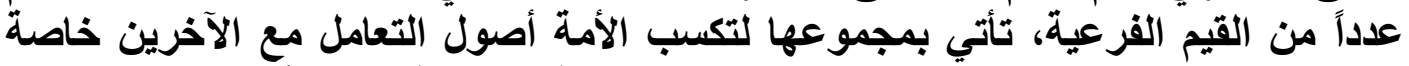

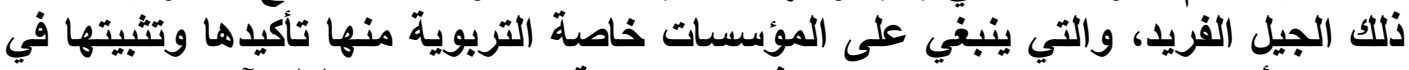

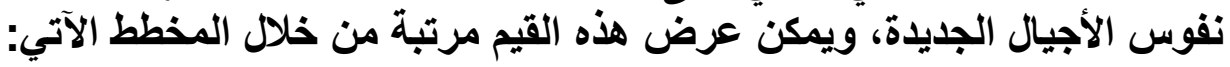

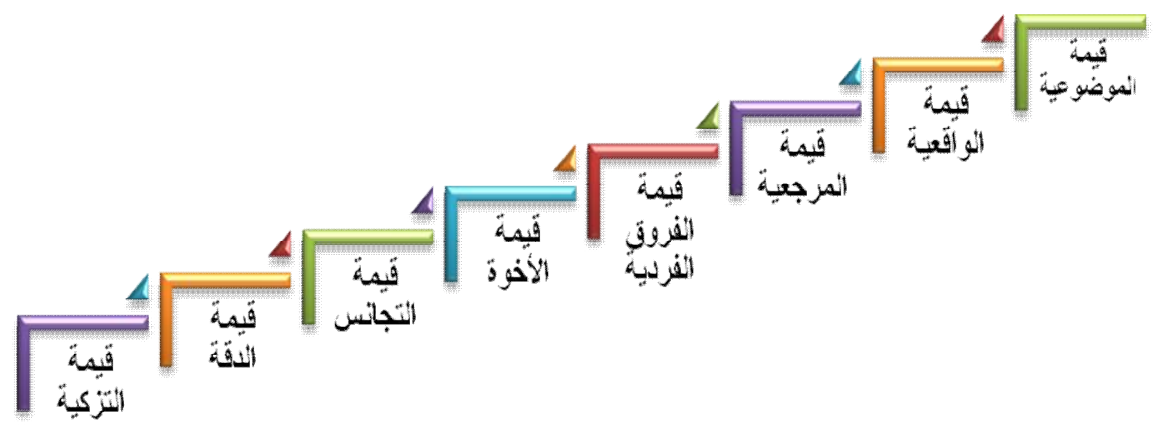

أما عن تفصيل المنظومة القيمية فهي في المطالب الآتية:

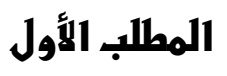

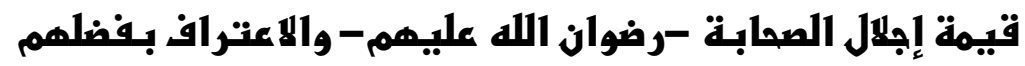

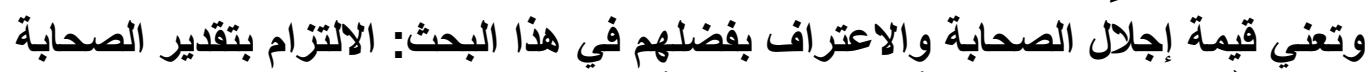

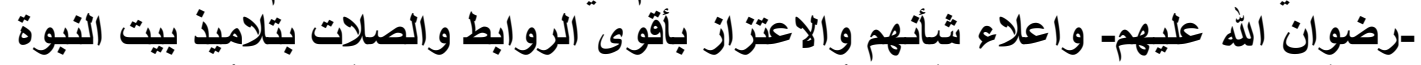

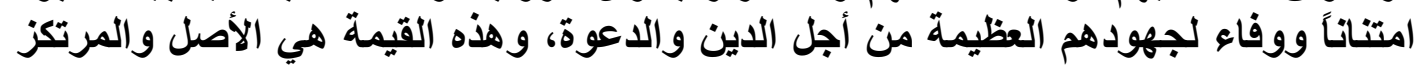

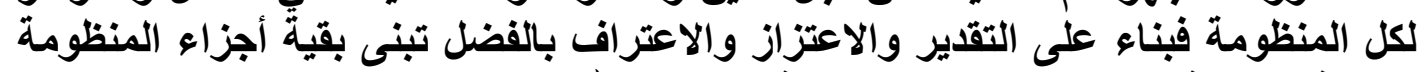

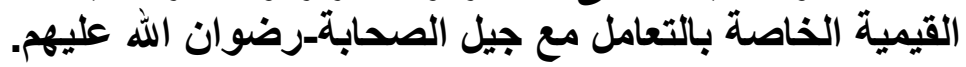


وقد جاعت في حق الصحابة -رضوان الله عليهم- كثير من الشهادات الإلهية، فالقاري

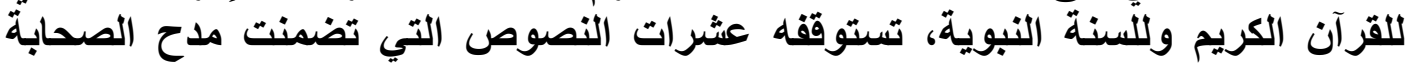

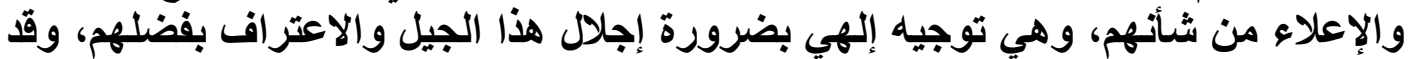

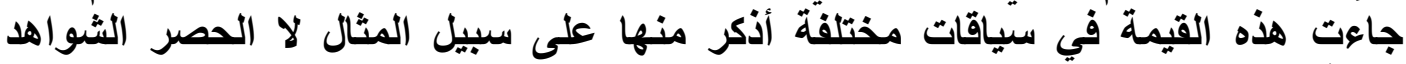

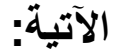

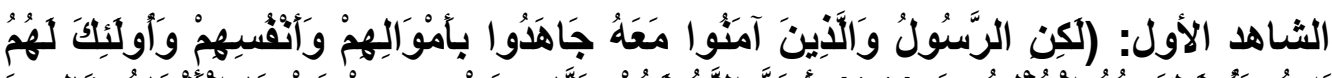

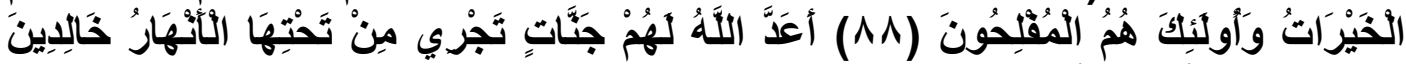

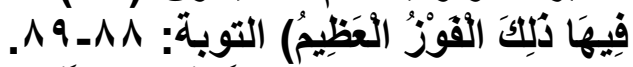

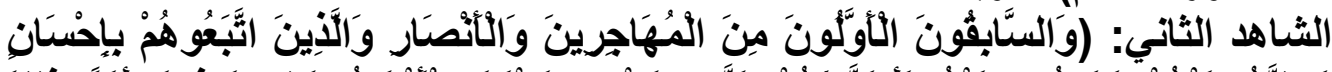

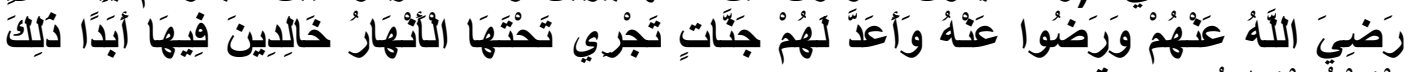

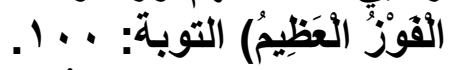

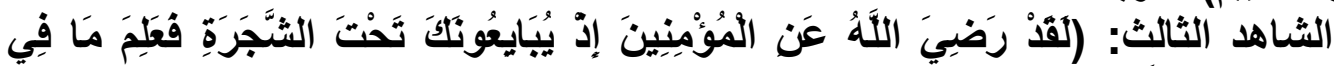

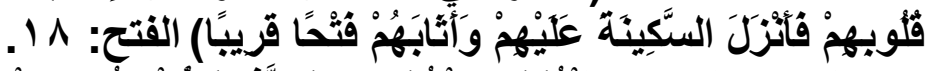

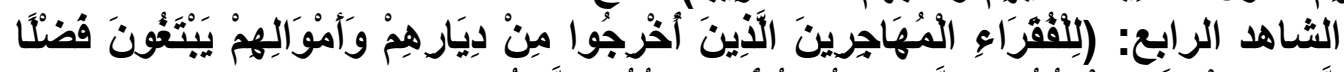

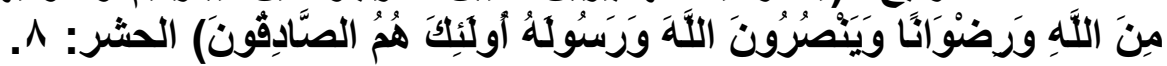

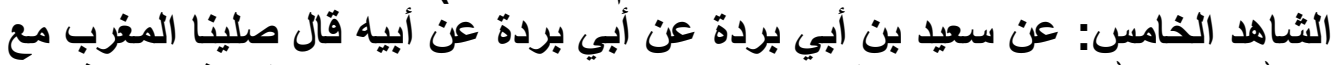

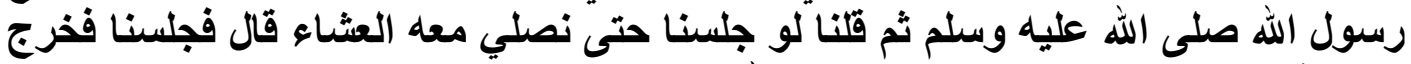

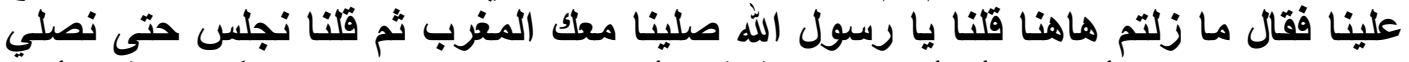

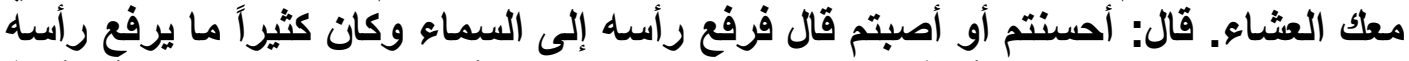

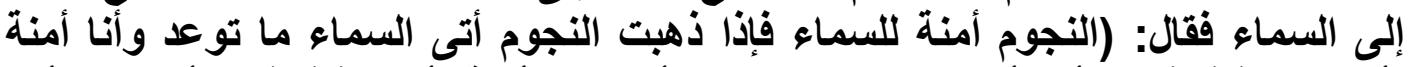

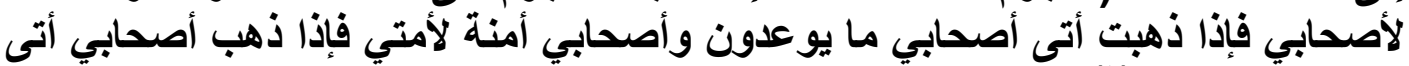

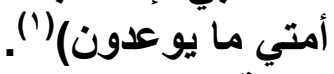

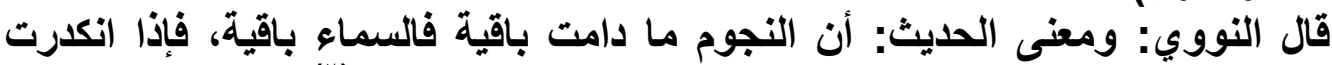

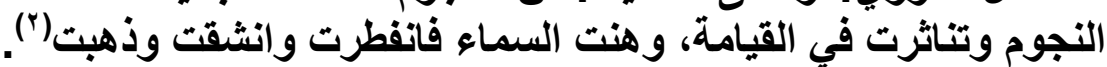

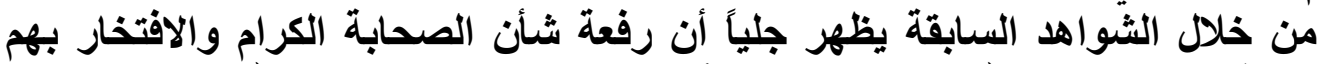

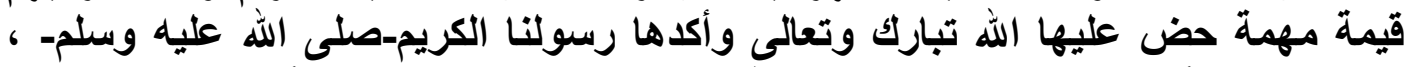

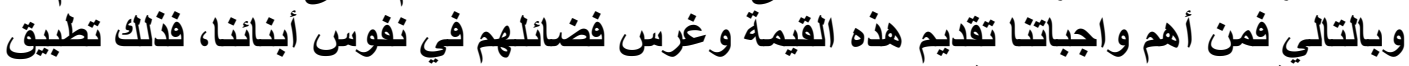

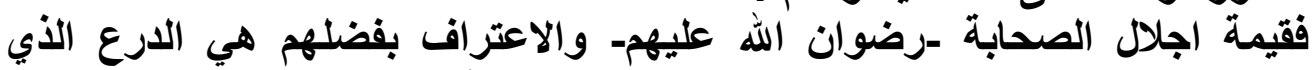

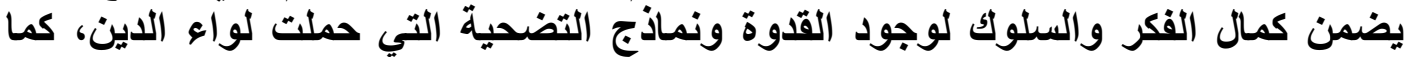

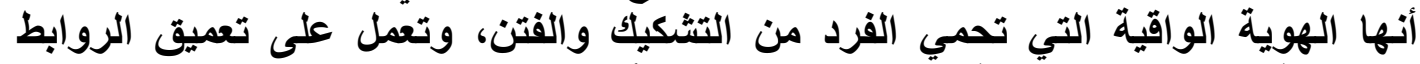

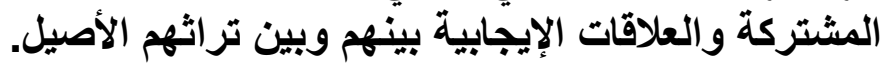

(') رواه مسلم، كتاب فضائل الصحابة، باب بيان أن بقاء النبب -صلى الله عليه وسلم- أمسان لأصحابه

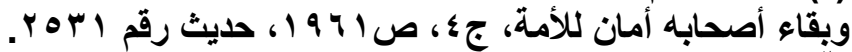

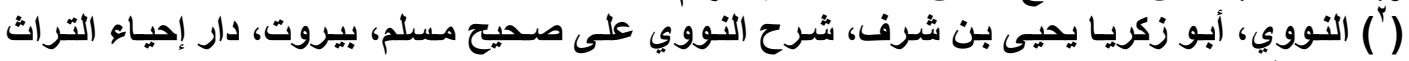

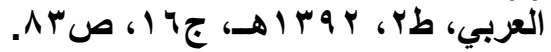


يقول ابن تيمية مفصحاً عن أهمية هذه القيمة: " وكل مؤمن آمن بالله فللصحابة

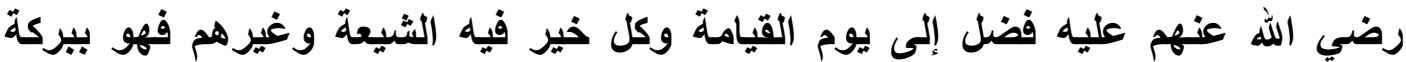

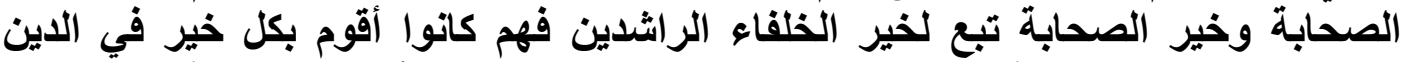

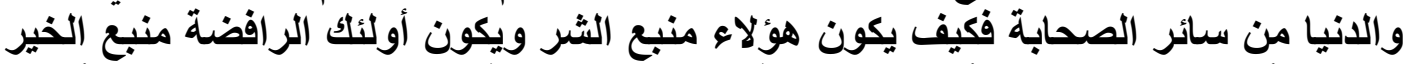

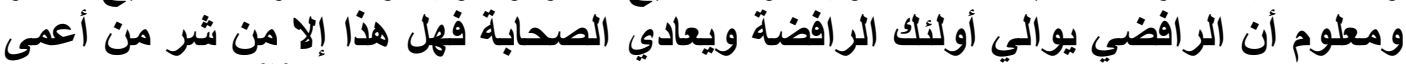

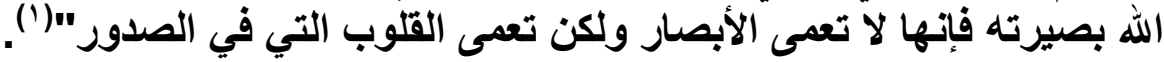
المطلب الثاني الثي

قيمة تزكية جيل الصحابة -رضوان الله عليهم- والسمو بهم عز كل ما يسيء

\section{إليهم}

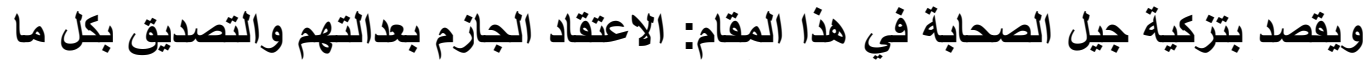

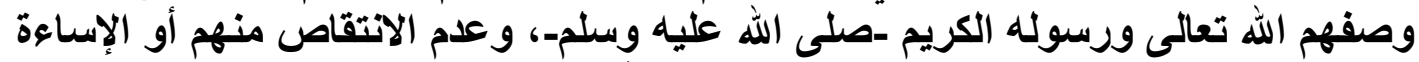

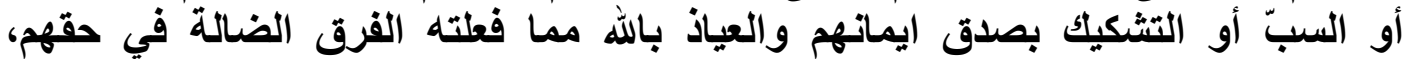

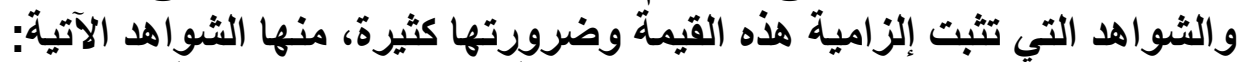

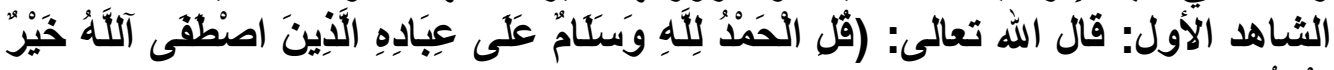

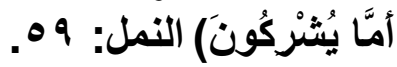

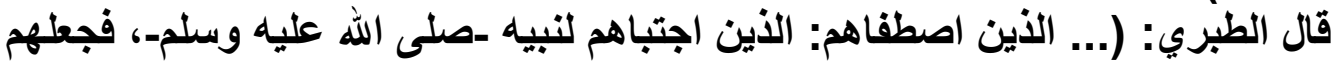

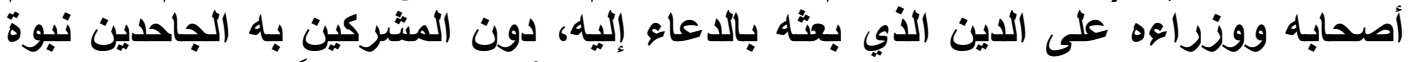

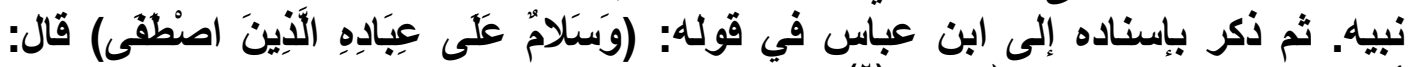
أصحاب محمد اصطفاهم الله لنبيه (بان).

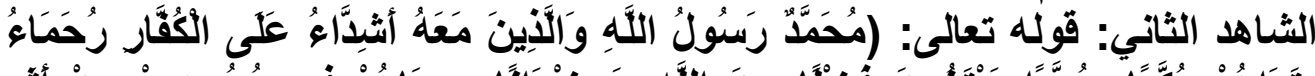

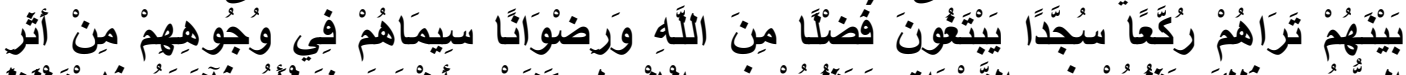

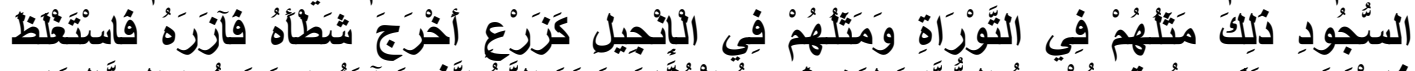

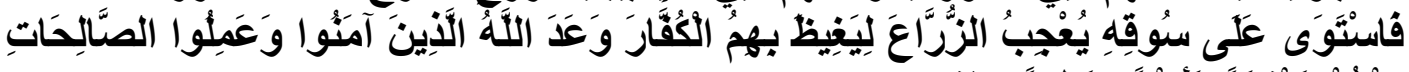

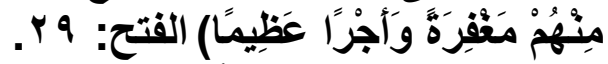

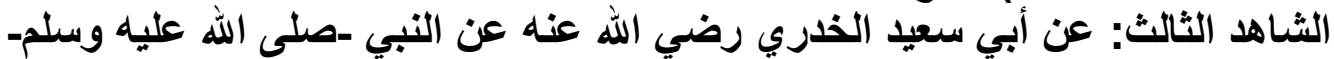

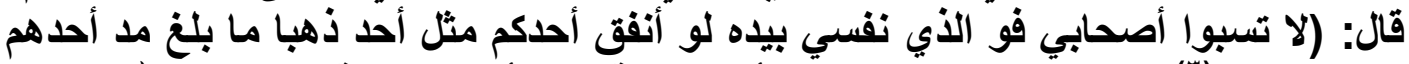

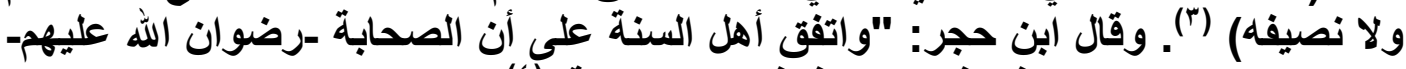

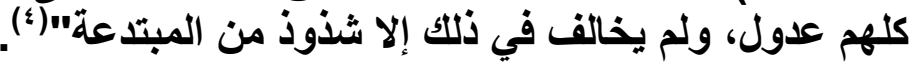

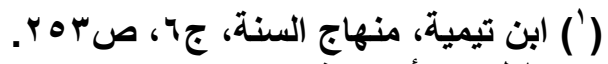
(ا) الطبري، أبو جعفر محمد بن جرير بن يزيد بن خالد الطبري، جامع البيان في تفسير القرآن، بيروت،

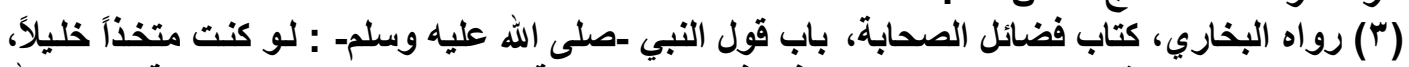

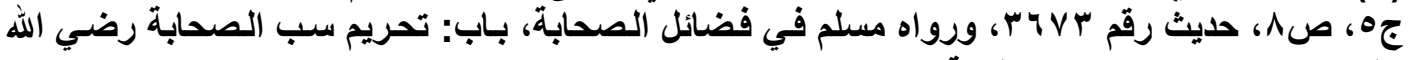

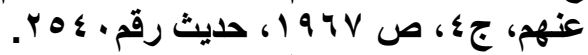

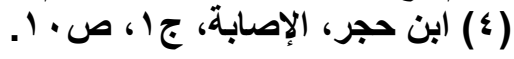




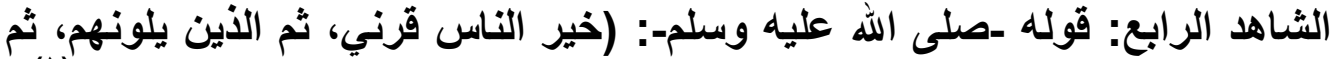

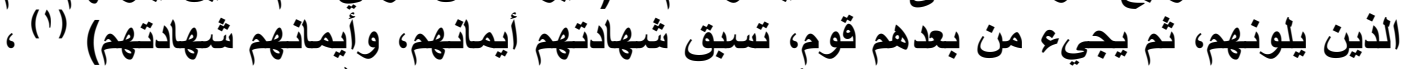

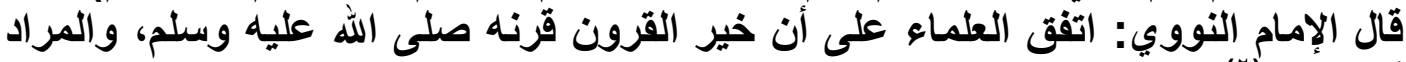

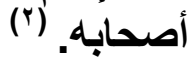

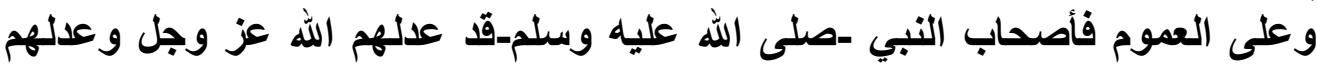

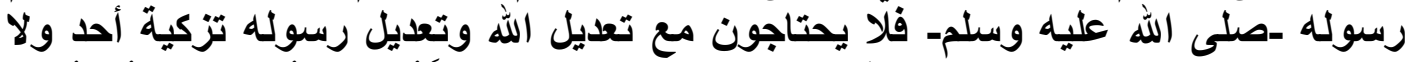

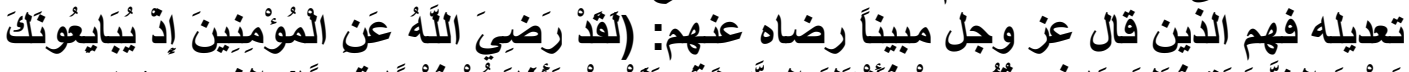

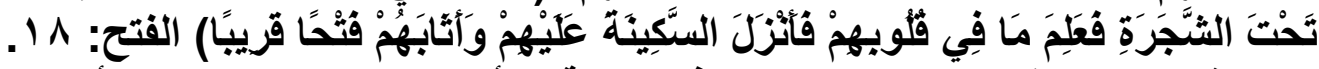

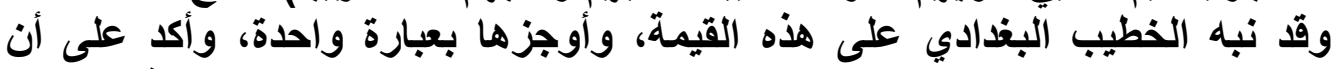

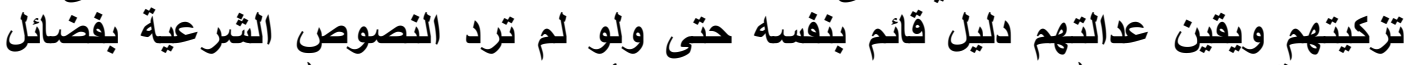

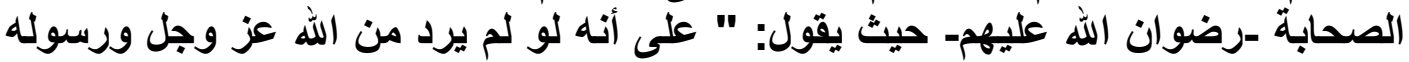

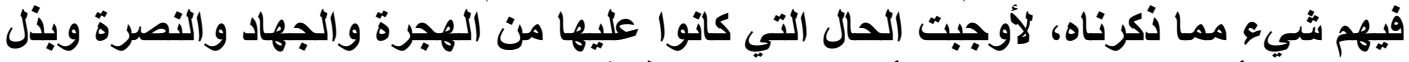

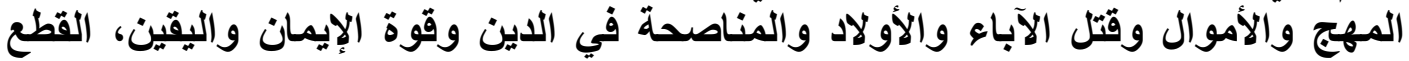

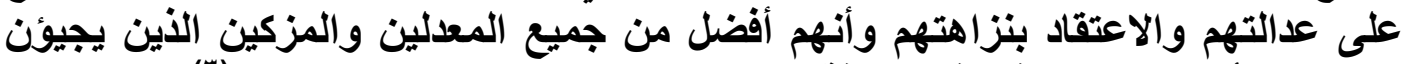
من بعدهم أبد الآبدين، هذا مذهب كافة العلماء ومن يعتد بقوله من الفقهاء" (").

\section{المطلب الثالث}

\section{قيمة الدقة والعمو في قراءة سيرهم}

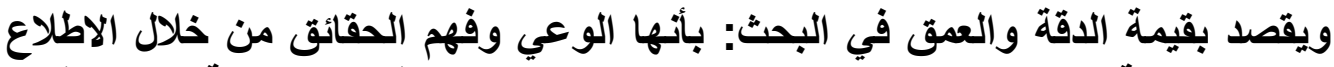

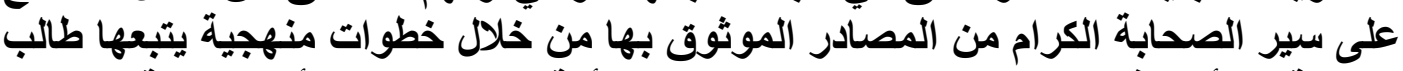

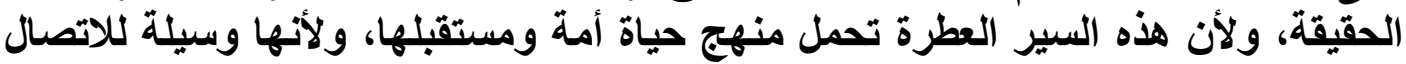

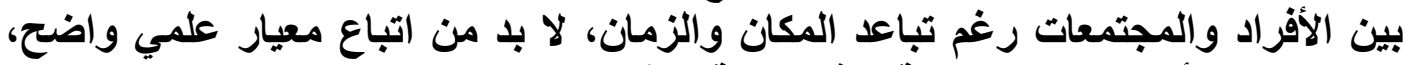

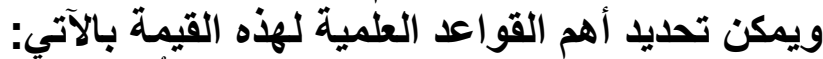

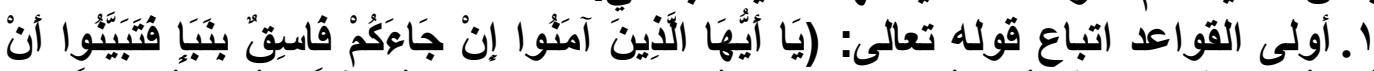

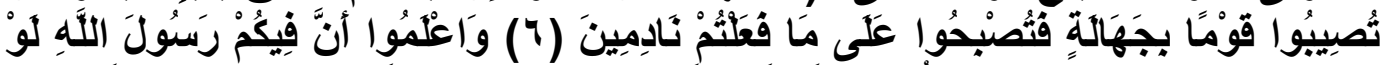

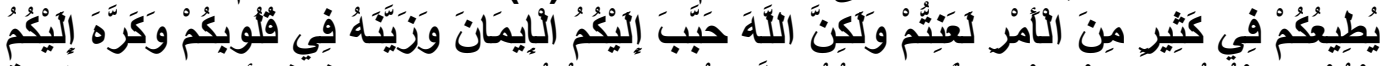

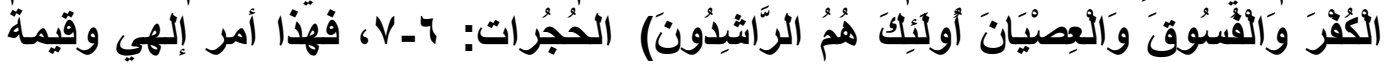
علمية منهجية علينا اتباعها والالتزام بهام التها. r. التثبت من المصادر والمراجع ومن مؤلفيها وأغراض كتاباتهم، فالأصل هو الرجوع إلى المصادر الثرعية الأصيلة.

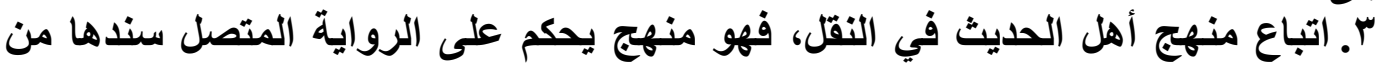

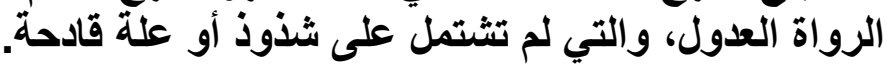

(') رواه البخاري، كتاب الثهادات، باب لا يشها على شهادة جور إذا شهة، ج"، ص اV ا، حليث رقم

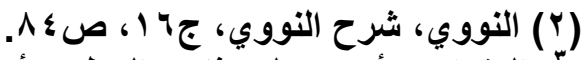

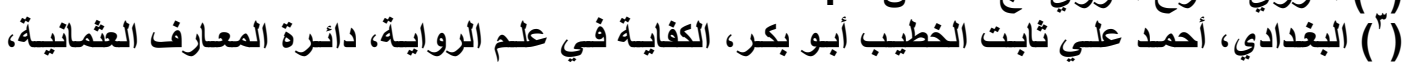
. 
إن مبدأ السرد لكل ما نقرأ ونسمع ونقل كل الروايات التي تصل إلينا من أخطر الآفات

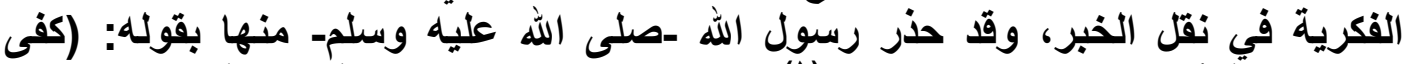

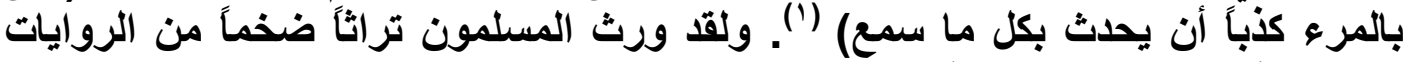

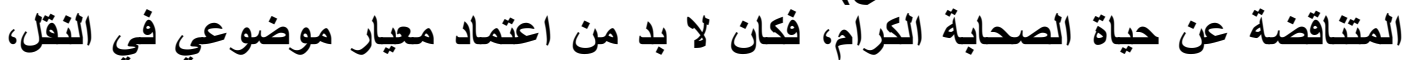
واعتبار صحة الأسانيا. وتظهر هذه القيمة أهمية قراعة سبير الصحابة ـرضوان الله عليهه-، وإدراك فوائد

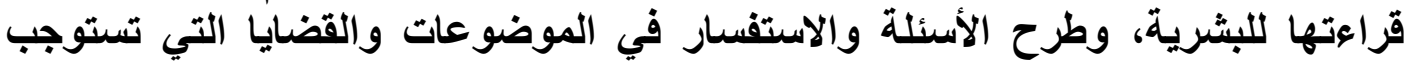

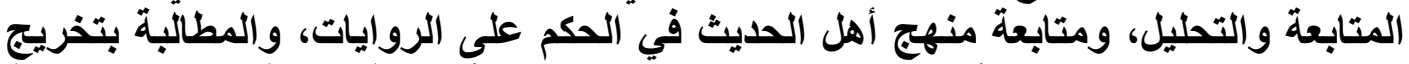

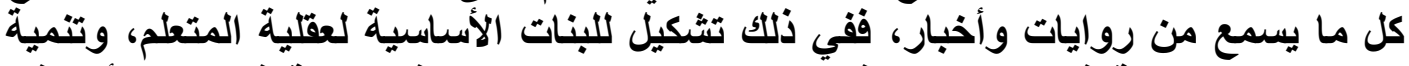

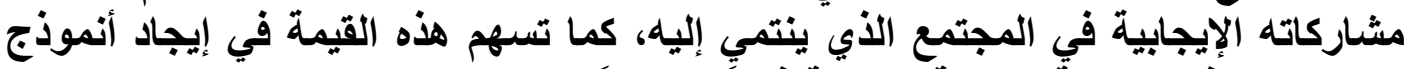

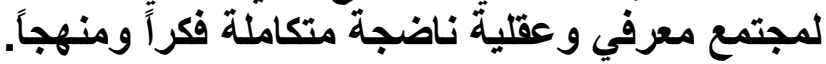

\section{المطلب الرابر ومئر}

\section{قيهة التجانسر فيها بينهم في النقاقة والنوميهات}

ظل النبي -صلى الله عليه وسلم- ثلاثة عشر عاماً في مكة، "كانت مهمته التهاته الأساسية

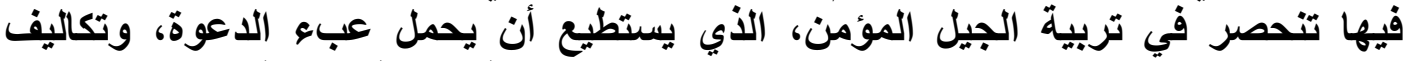

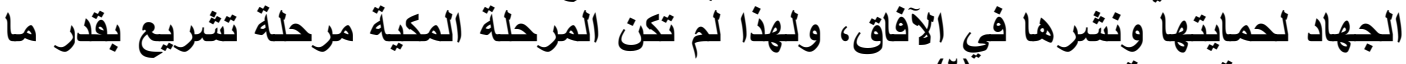

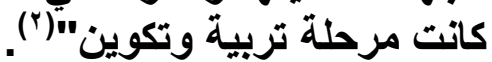

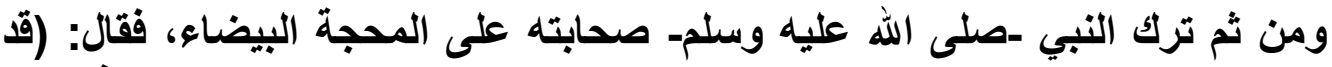

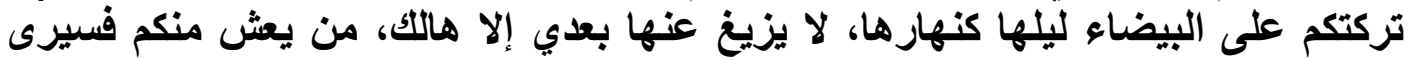

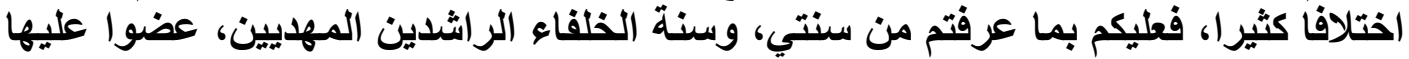

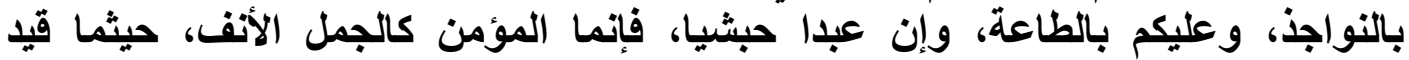

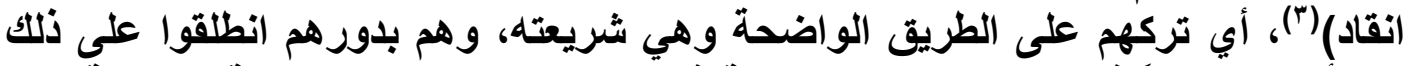

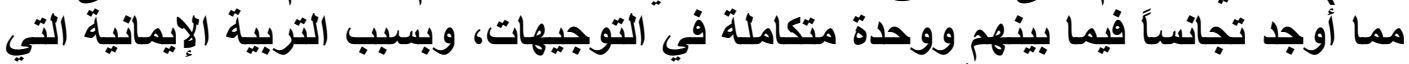

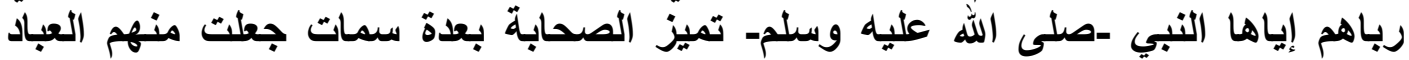

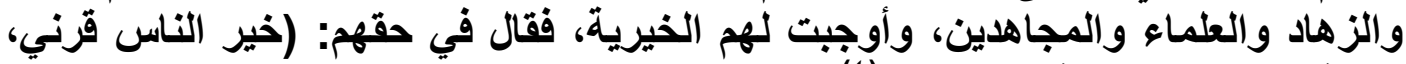

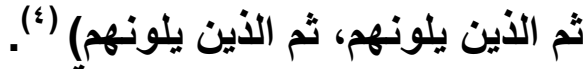

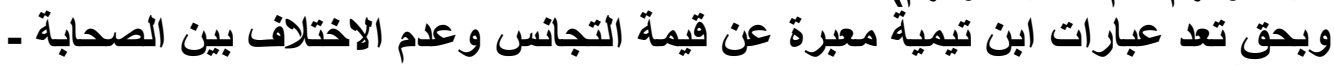

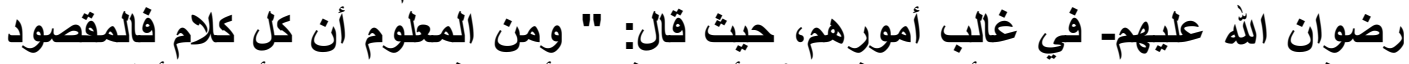

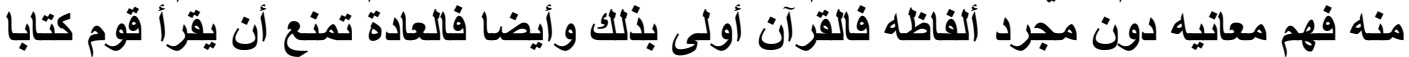

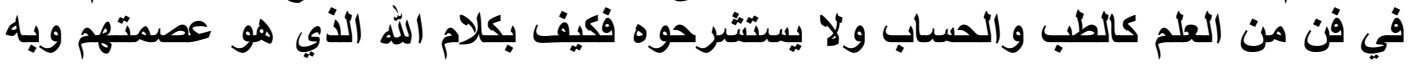

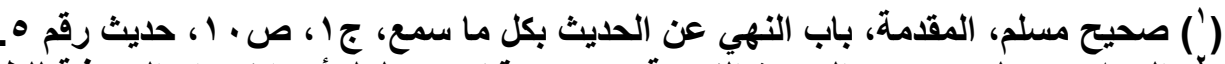

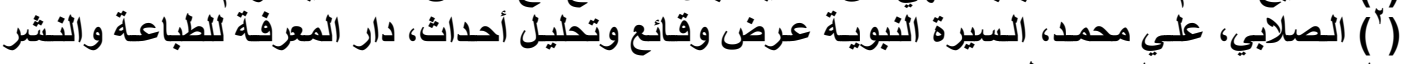

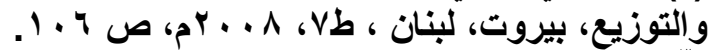

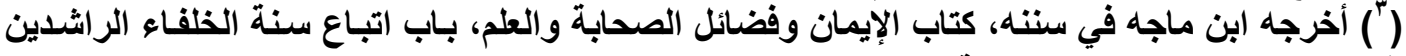

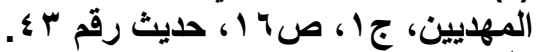


نجاتهم وسعادتهم وقيام دينهم ودنياهم ؟ ولهذا كان النزاع بين الصحابة في تفسير القرآن

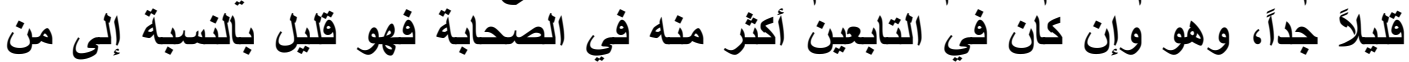

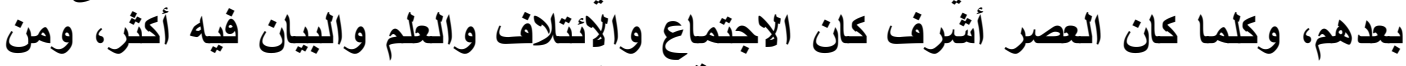

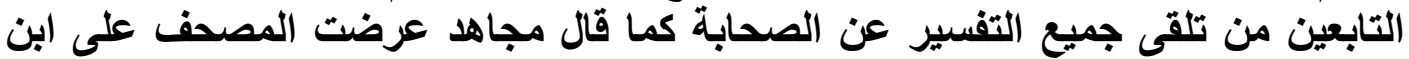

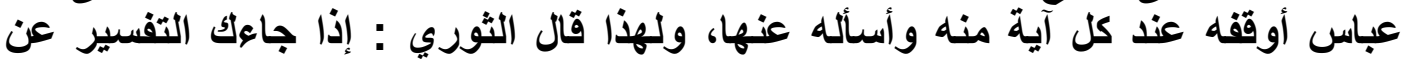

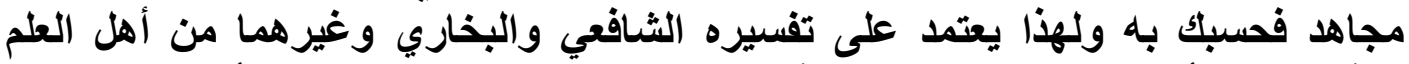

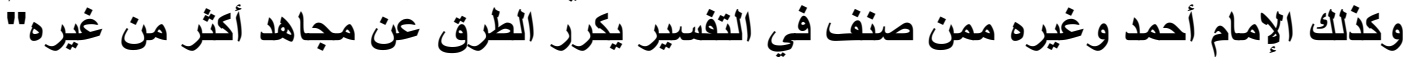

كما أن في التجانس والتوافق رقي في الذوق والاحترام المتبادل والسكينة والاطمئنان

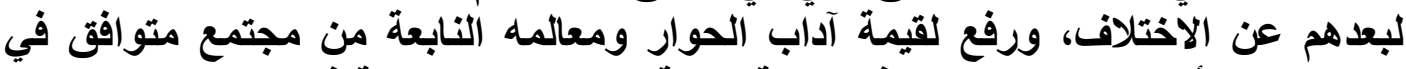

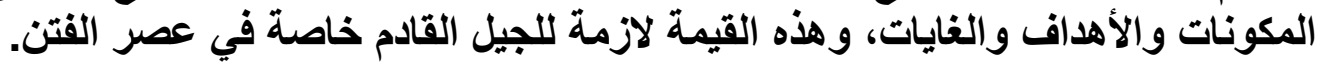

\section{المطلب الفامسر لألها}

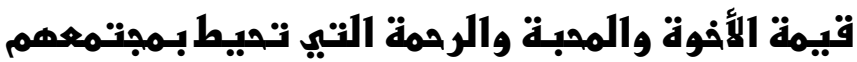

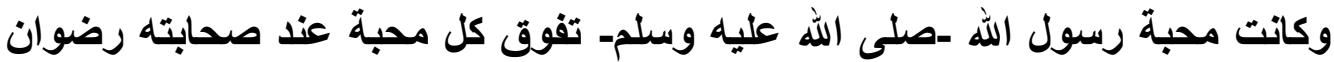

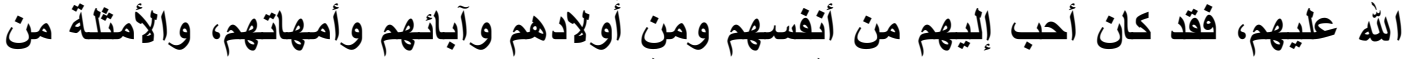

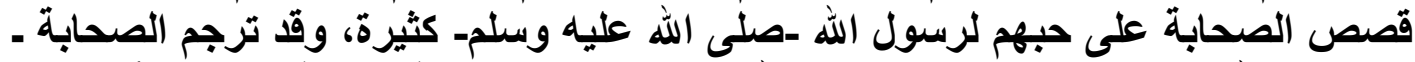

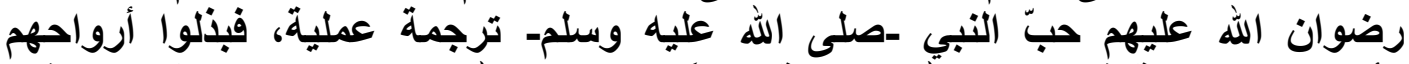

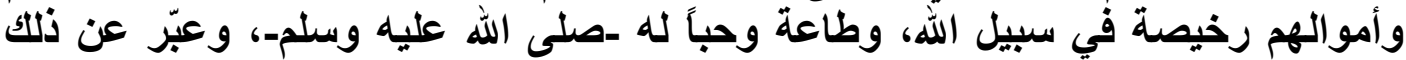

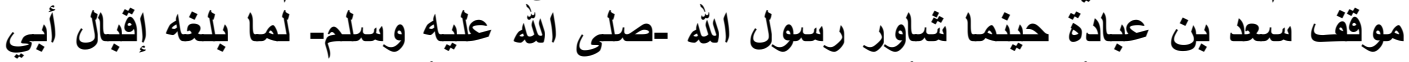

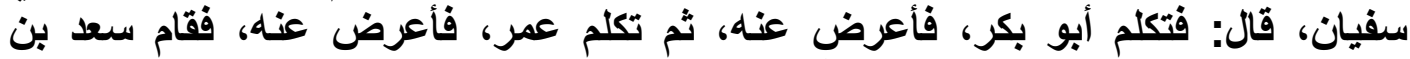

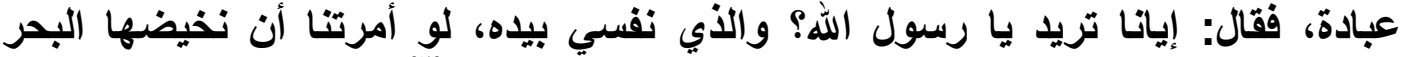

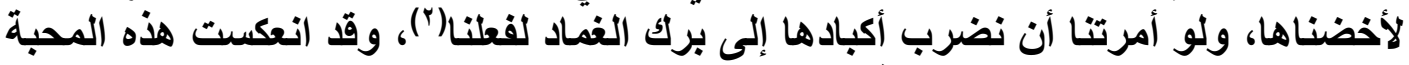

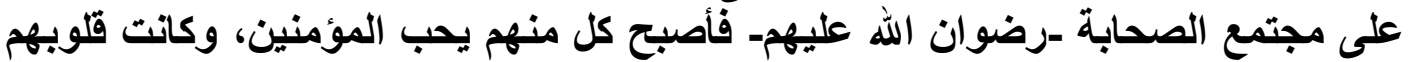

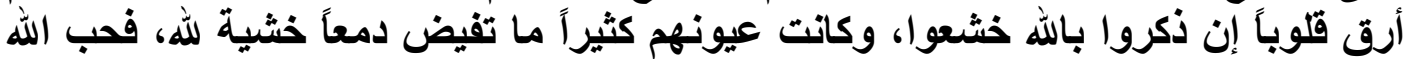

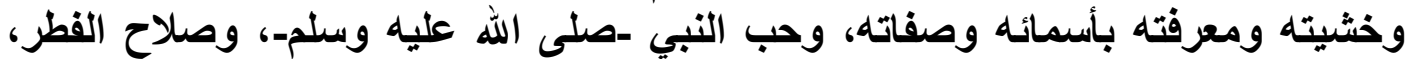

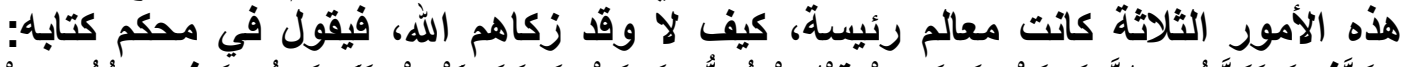

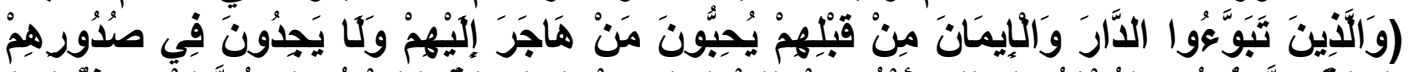

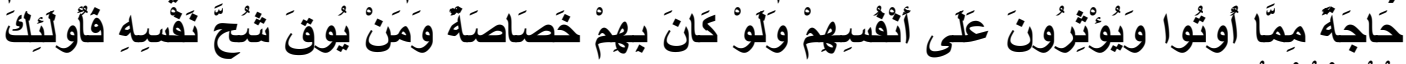

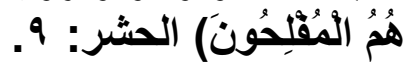

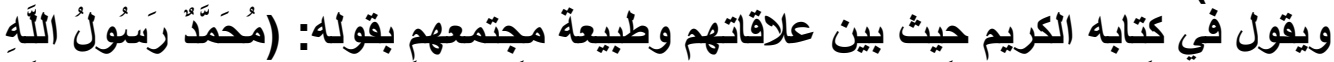

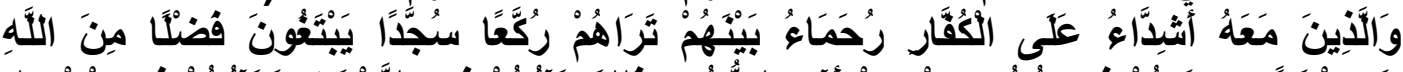

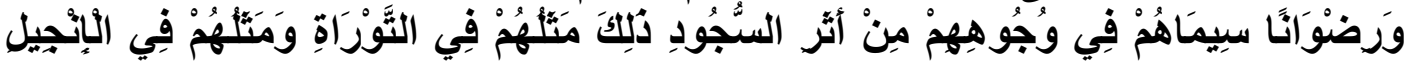

(') ابن تيمية، تقي الدين أبو العباس أحمد بن عبد الحليم، مجموع الفتاوى، تحقيق: أنور الباز، دار

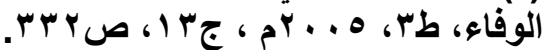

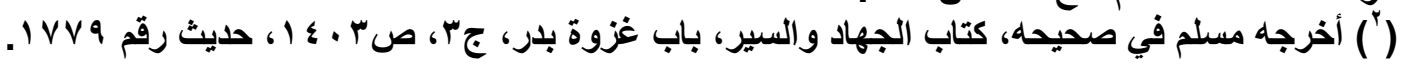




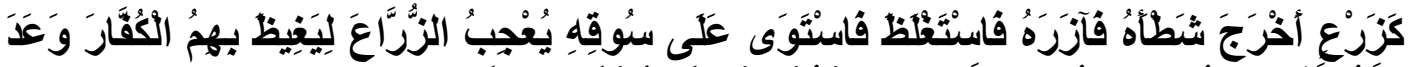

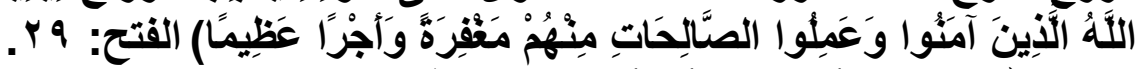

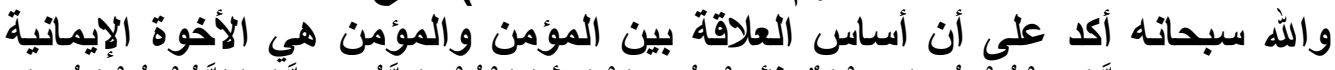

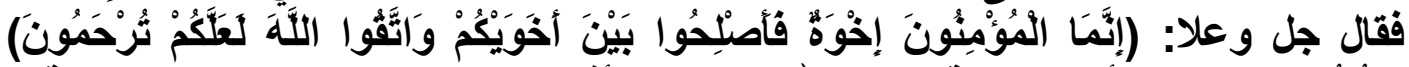

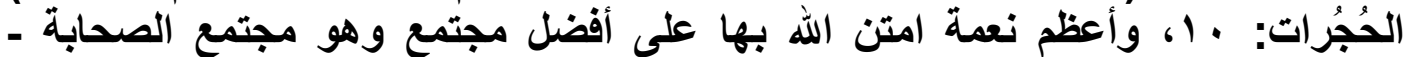

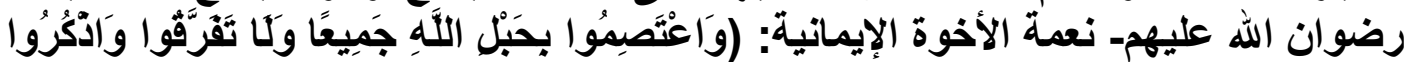

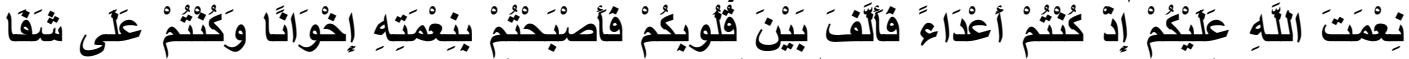

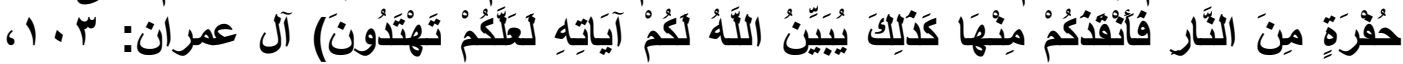

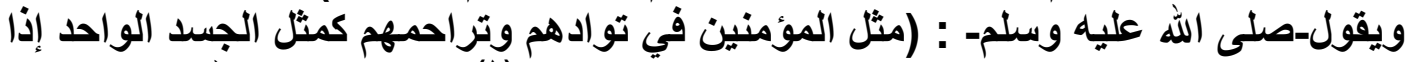

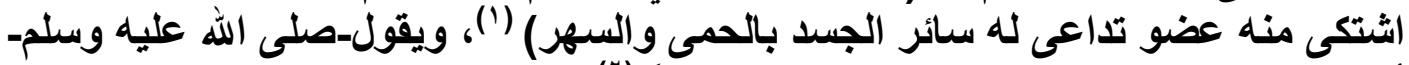

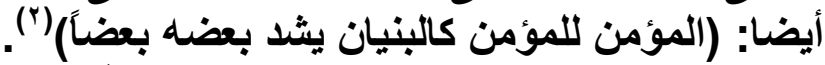

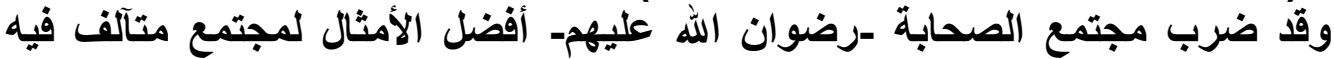

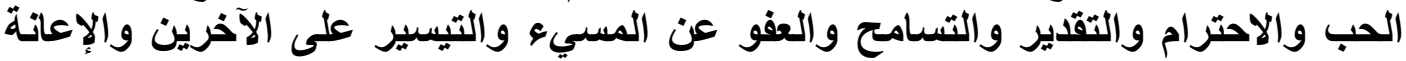

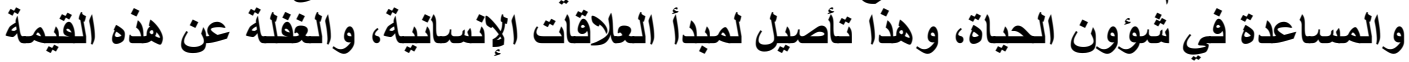
من أهم أسباب العنف والعدوان والقسوة والظلم الأي شاع في مجتمعاتنا المعاصرة.

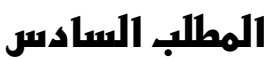

\section{قيمة الاعتراف بـالتنهاوت والننو ع في القدرات والإمكانات}

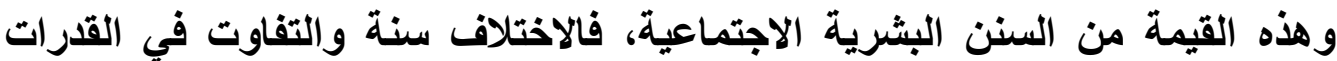

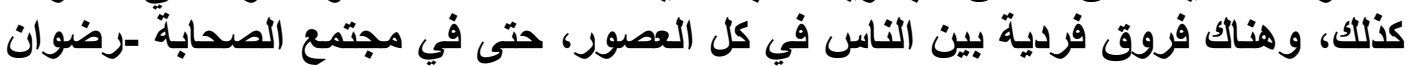

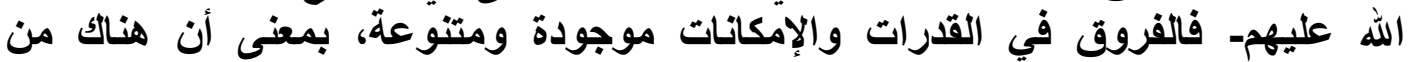

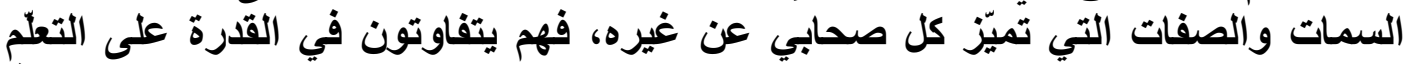

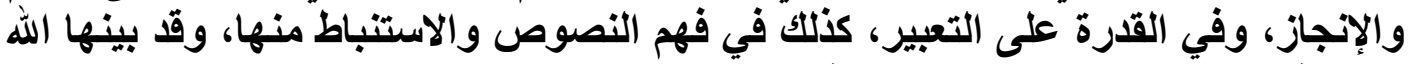

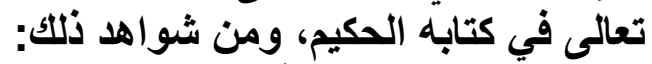

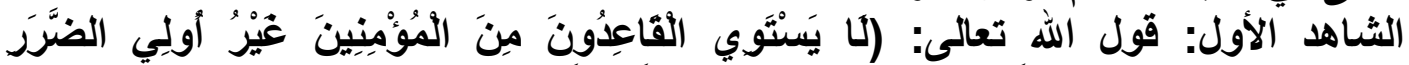

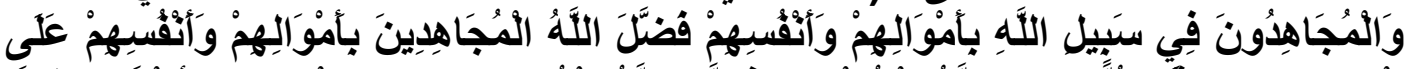

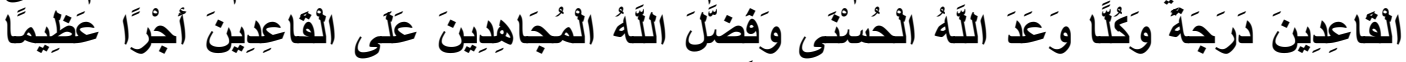

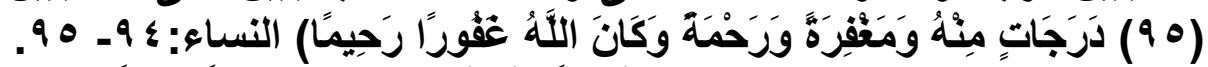

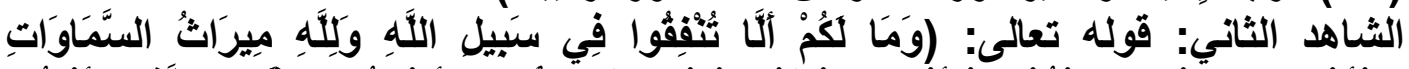

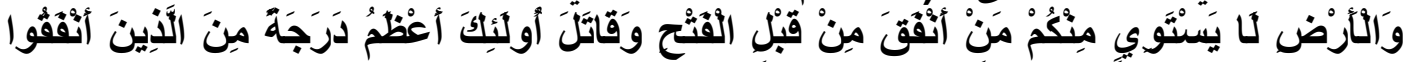

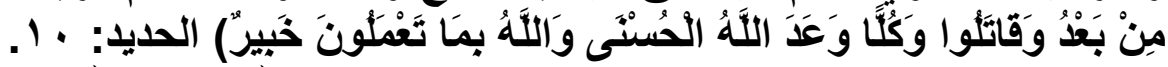

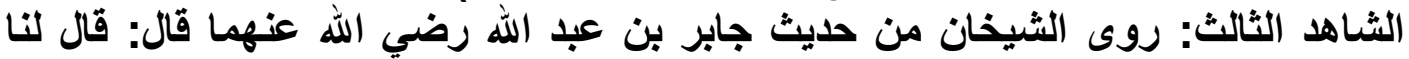
رسول الله صلى الله عليه وسلم يوم الحليبية: (أنتم خير أهل الأرض عند -وكنا ألفاً وأربعمائة.

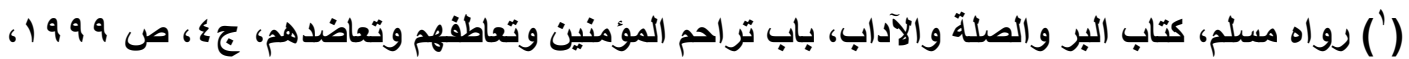

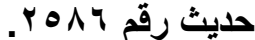

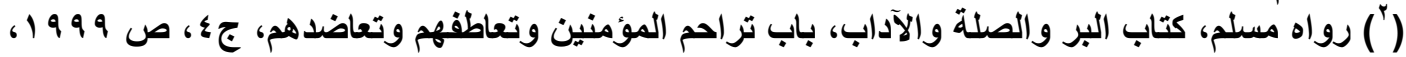


ولو كنت أبصر لأريتكم موضع الشجرة)('). هذا الحديث صريح في فضل أصحاب الشجرة

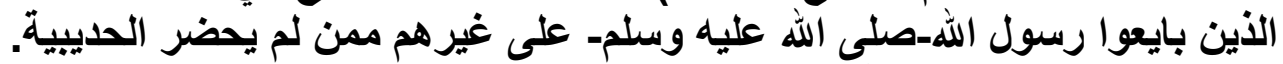

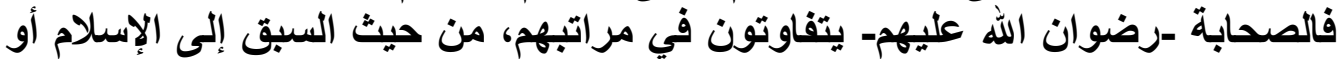

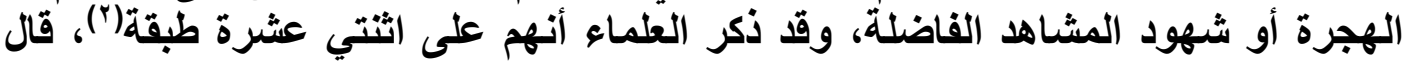

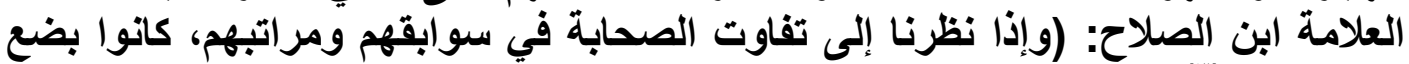

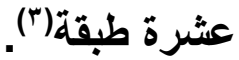
وقد كان أبو هريرة وعبد الله بن عمر أحفظ الصحابة للحديث وأكثرهم رواية لذه، وكان

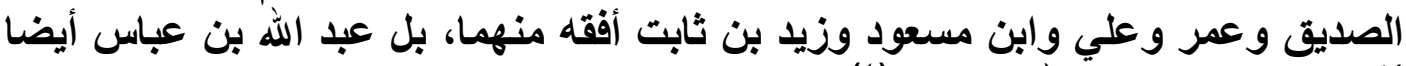

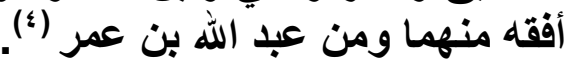
ومما سبق ينبغي التببه للمبادئ الآتية:

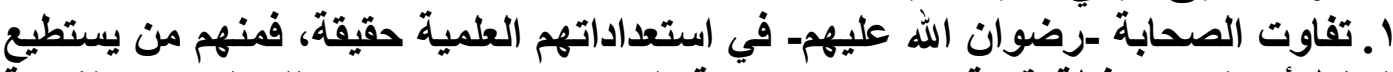

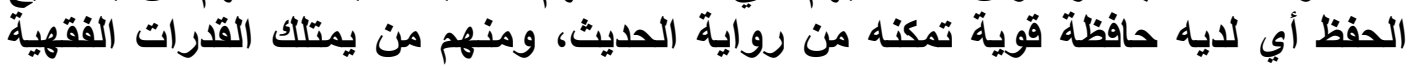

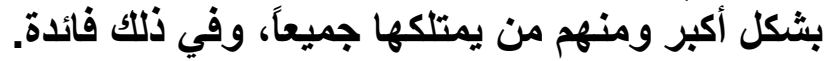

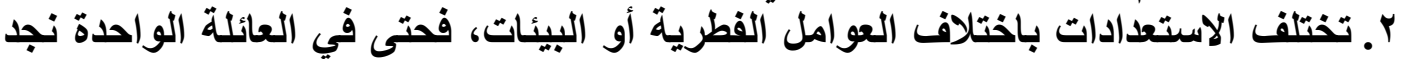

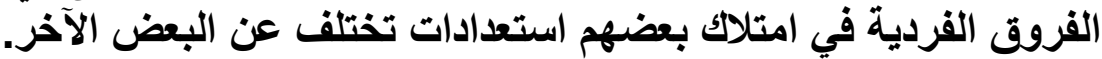

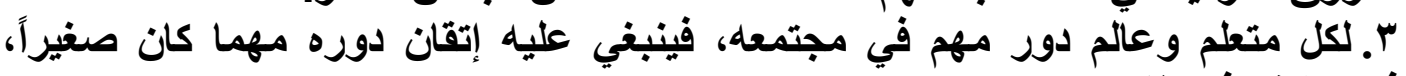

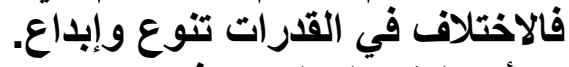

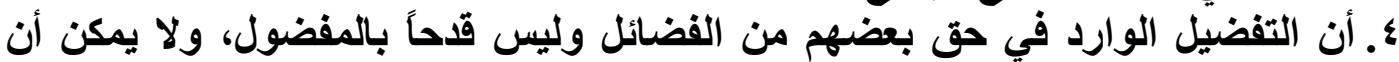

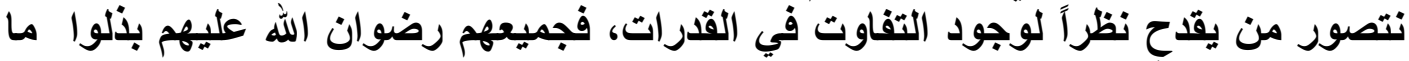

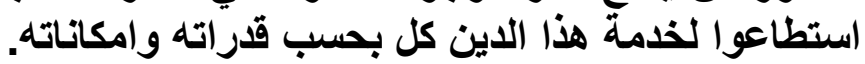

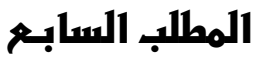

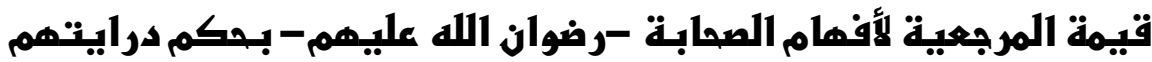

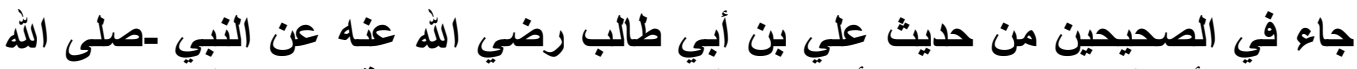

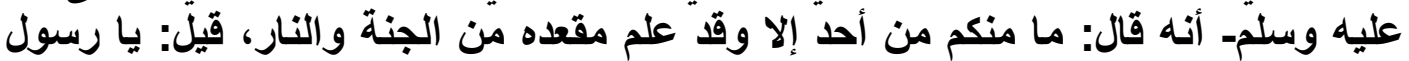

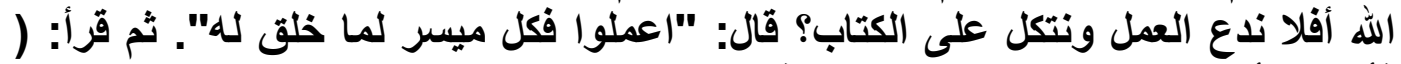

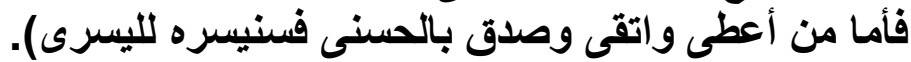

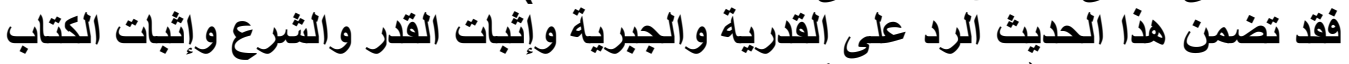

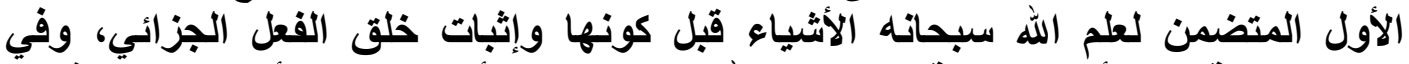

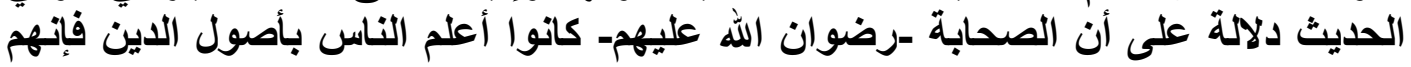

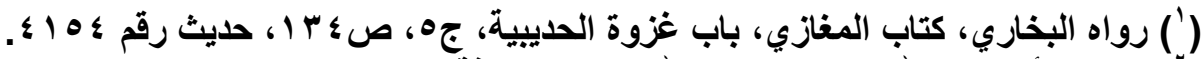

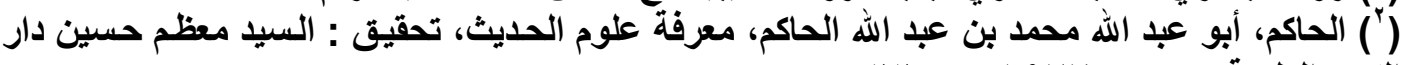

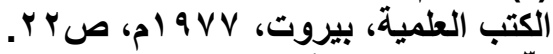
(") أبن الصلاح، أبو عمرو عثمان بن عبد الرحمن، مقدمة ابن الصلاح علوم الحديث، مكتبة الفارابي،

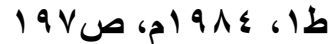
() أبن القيم، محمد بن أبي بكر أيوب الزرعي أبو عبد الله، إعلام الموقعين عن رب العالمين، تحقيق: طه

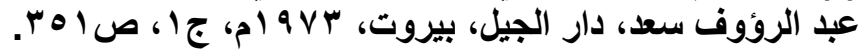




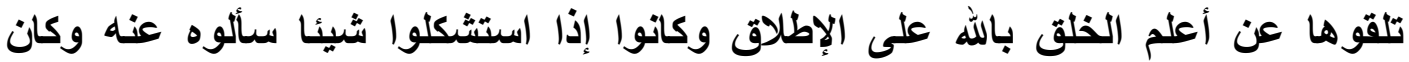

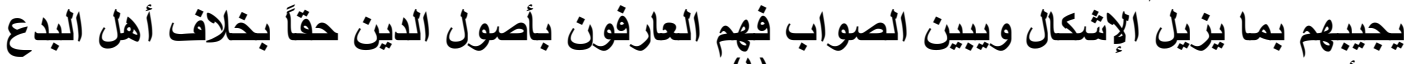

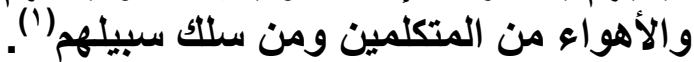

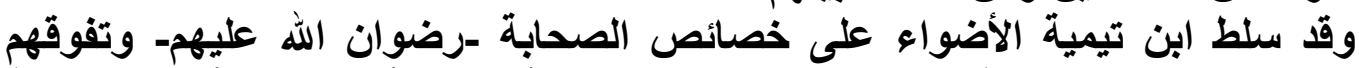

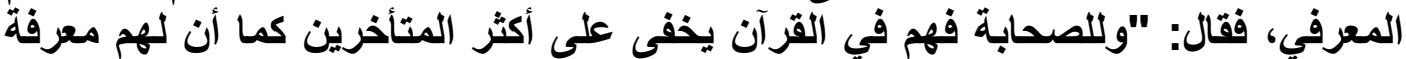

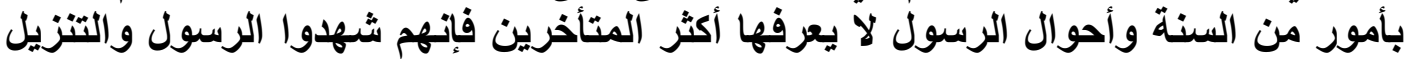

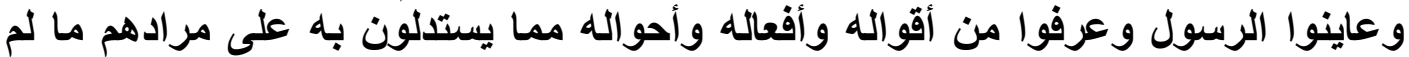

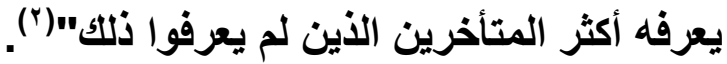

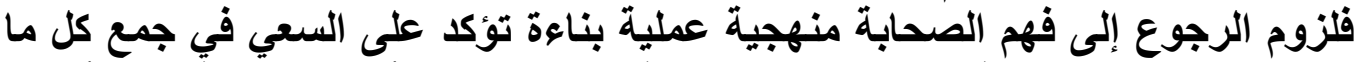

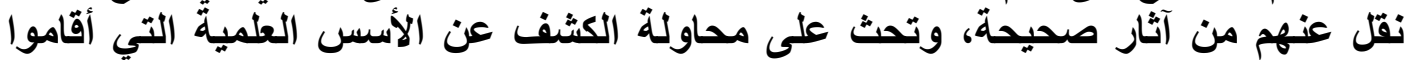

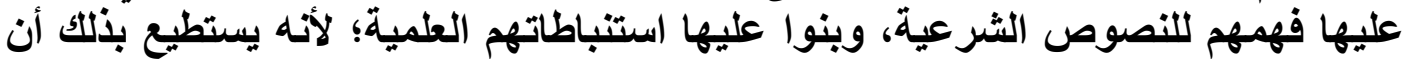

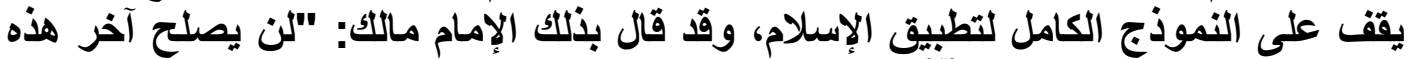

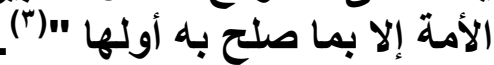

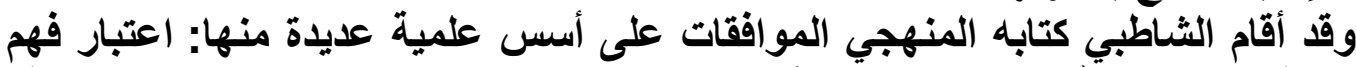

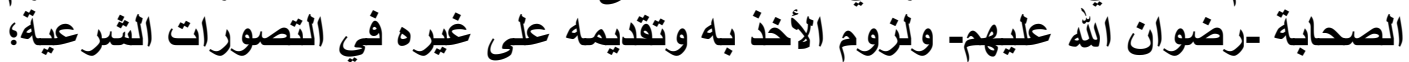

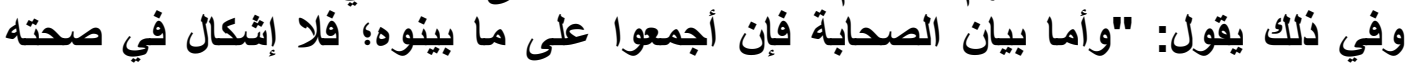

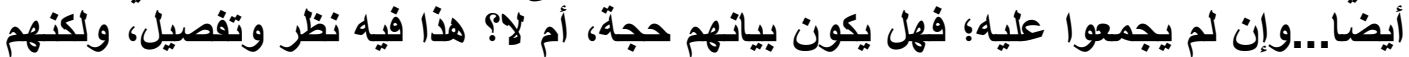

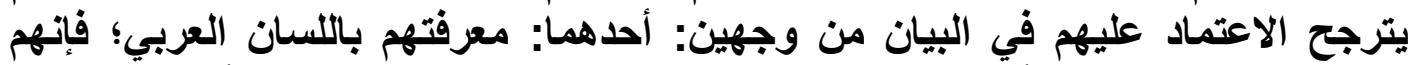

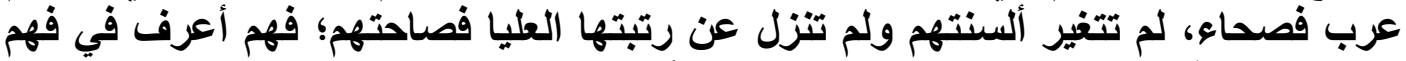

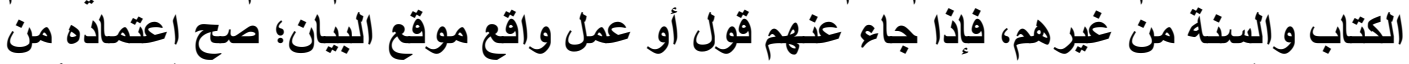

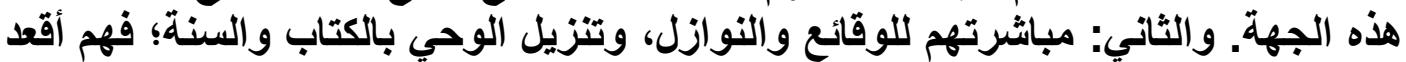

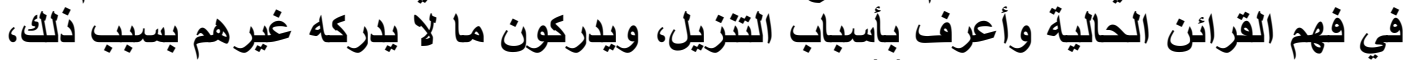

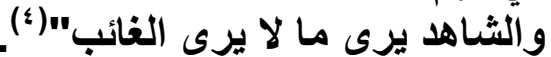

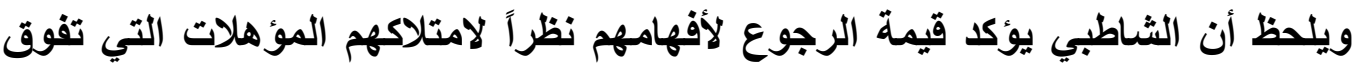

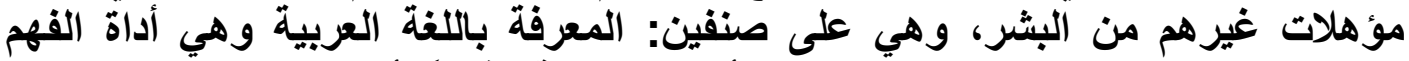

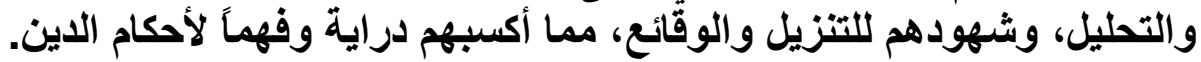

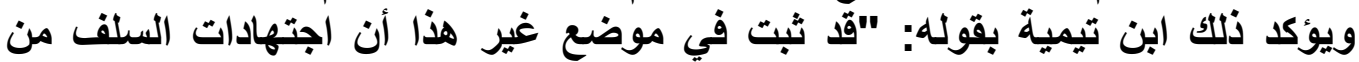

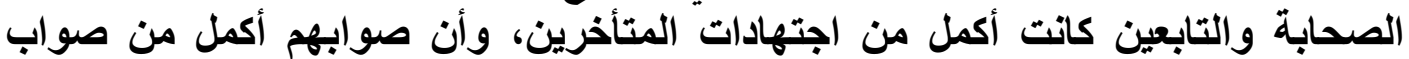

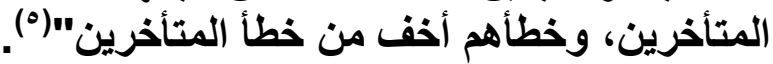

(') ابن قيم الجوزية، محمد بن أبي بكر أيوب الزرعي أبو عبد الله، التبيان في أقسام القرآن، دار الفكر،

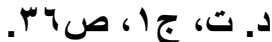

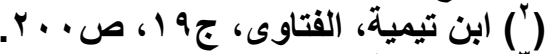

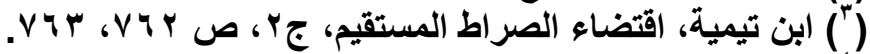

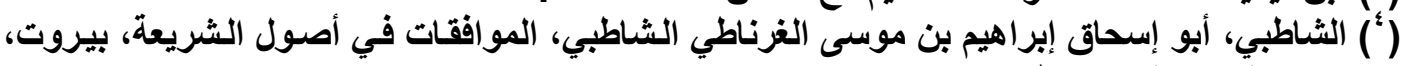

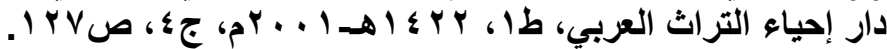

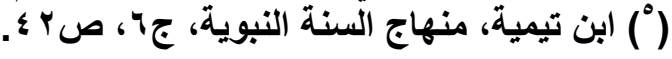




\section{المطلب الثامز}

\section{قبيمة التنعامل بـواقعبة مهر بشنربتهم}

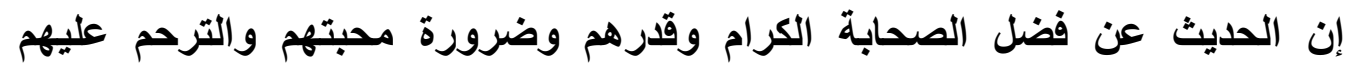

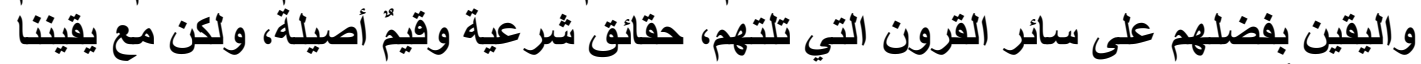

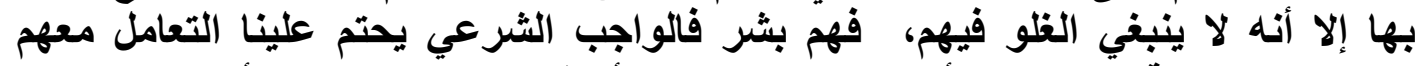

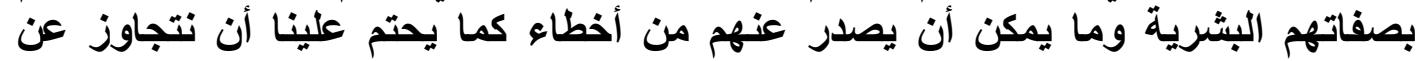

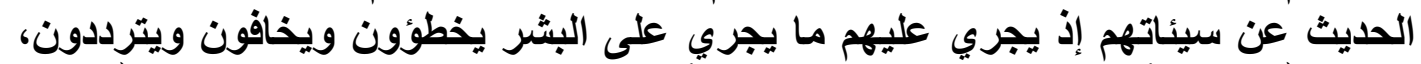

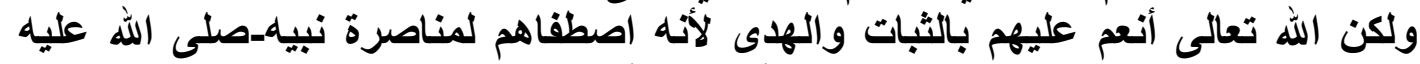

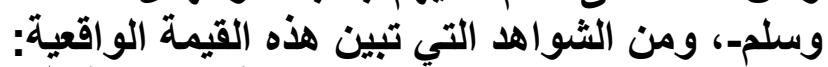

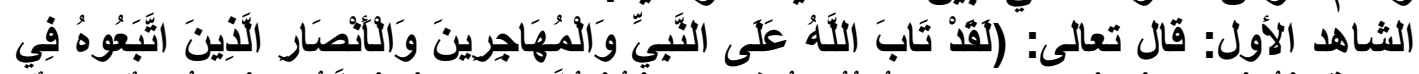

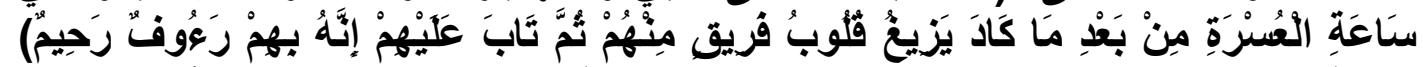

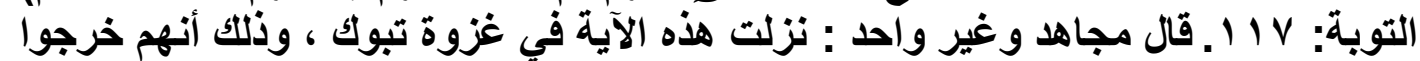

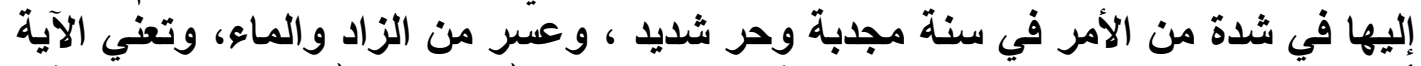

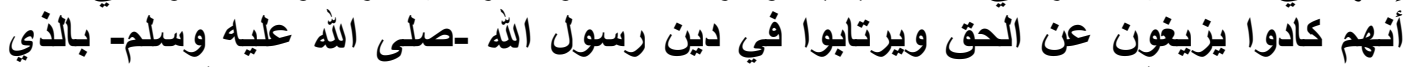

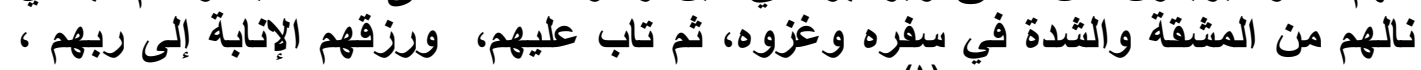

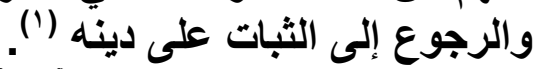

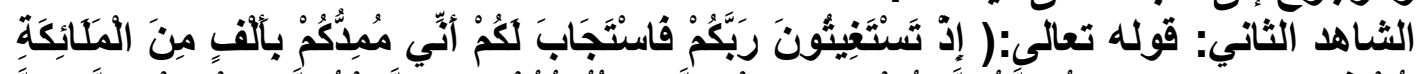

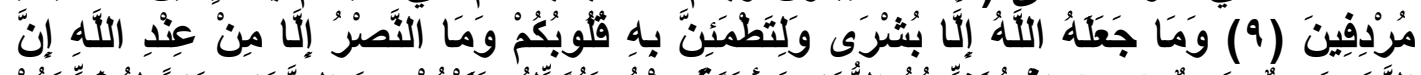

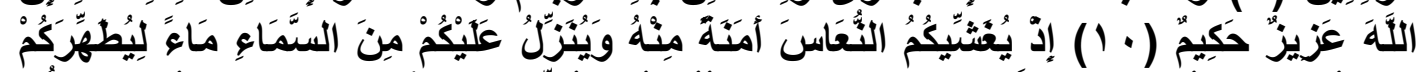

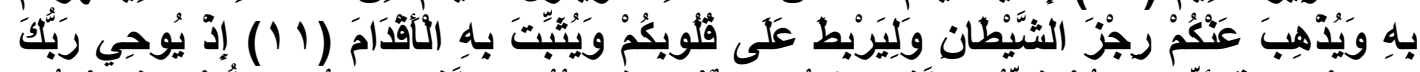

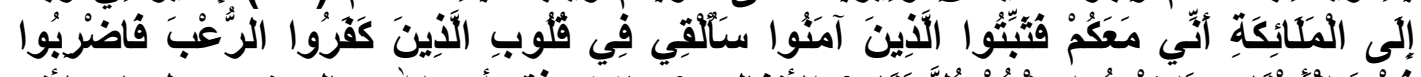

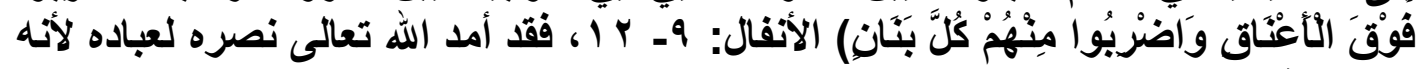

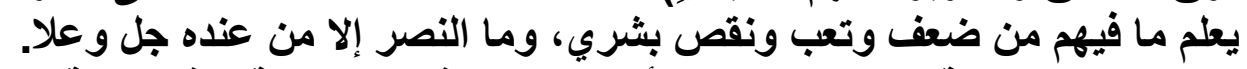

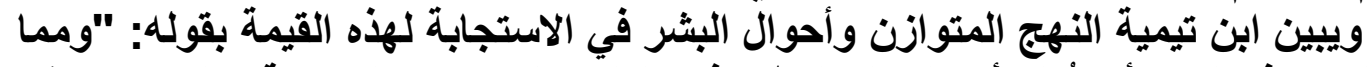

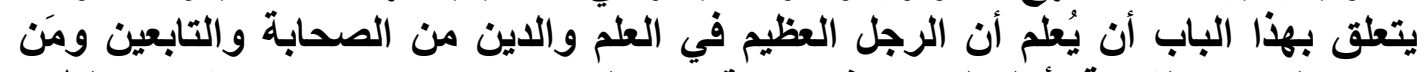

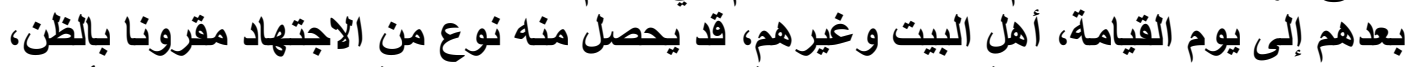

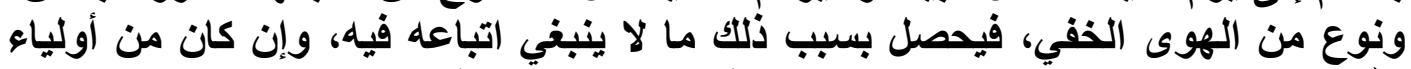

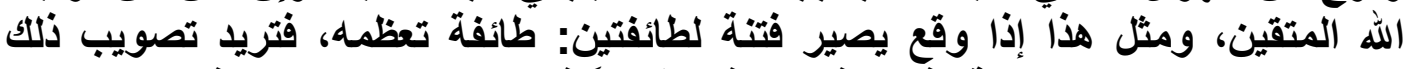

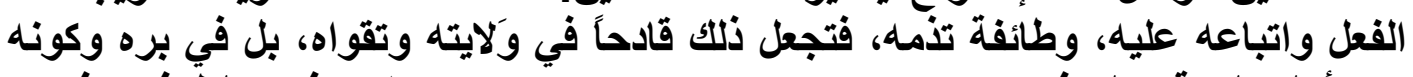

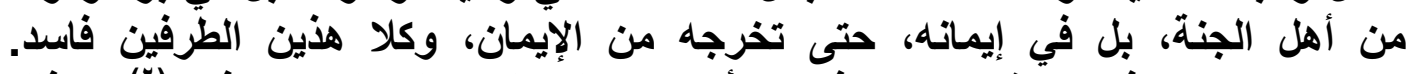

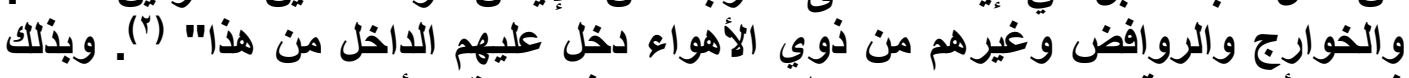

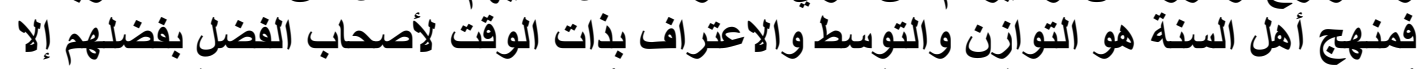
أن هذا الفضل والثلك المنزلة الرفيعة لا تمنع وقوع الأخطاء والاجتهنهادات الوات البشرية.

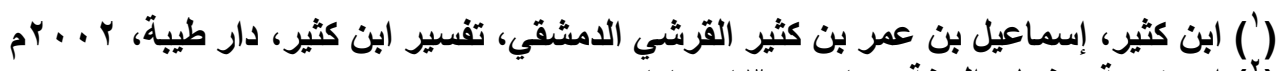

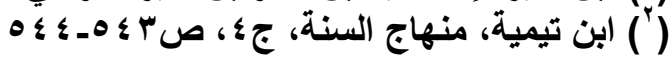




\section{المطلب الناستر}

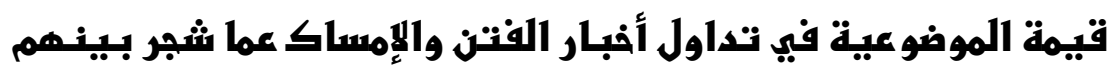

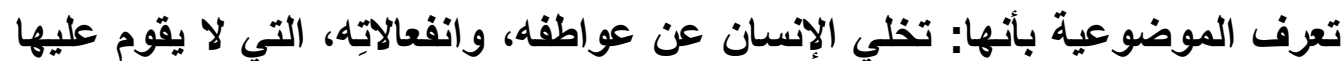

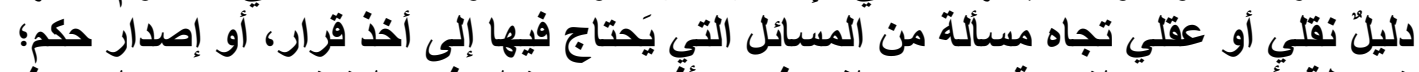

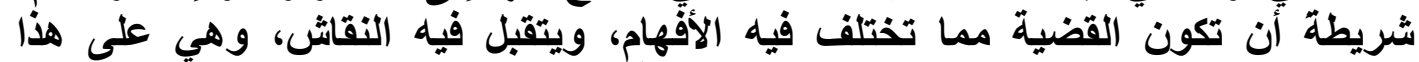

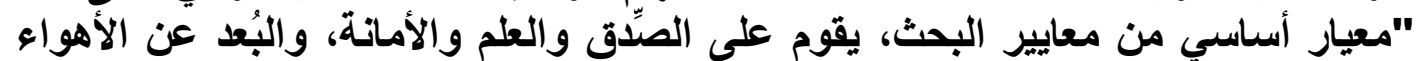

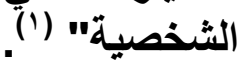

ومن التعريف لابد من توافر شروط مهمة لقيمة الموضوعية في تداول أخبار الصحابة

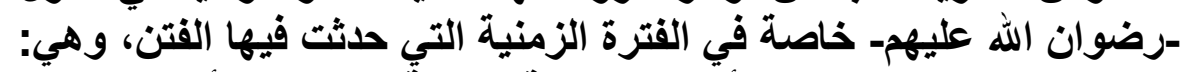

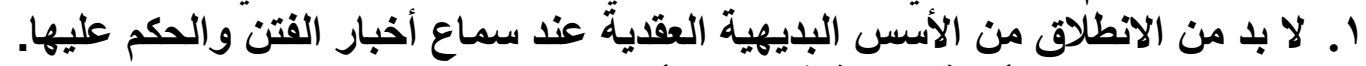

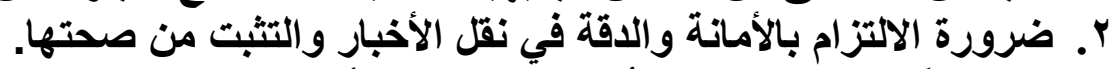

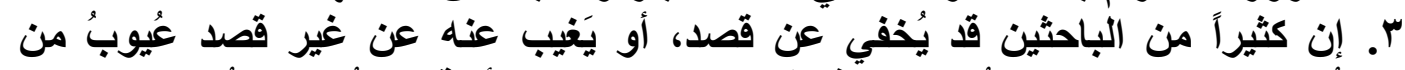

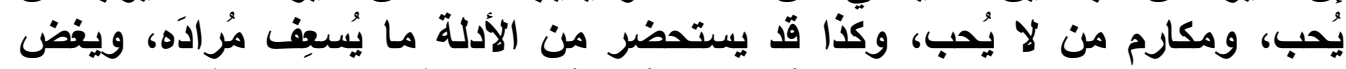

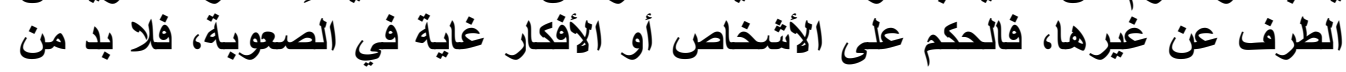

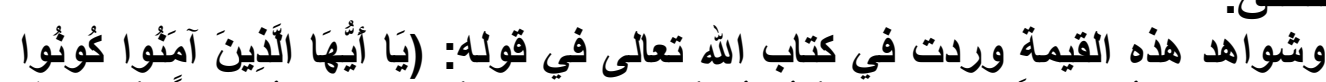

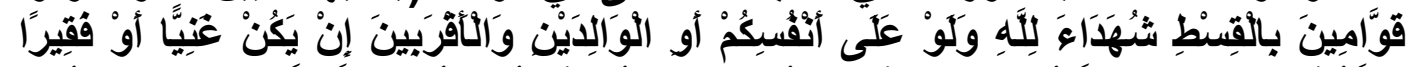

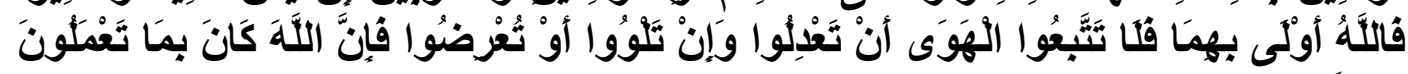

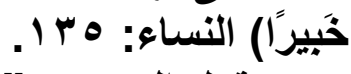

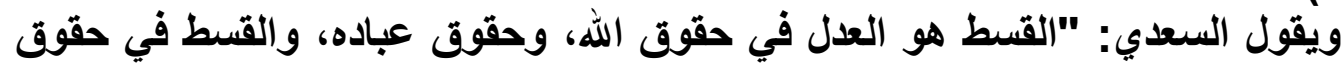

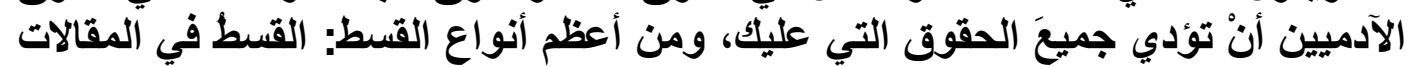

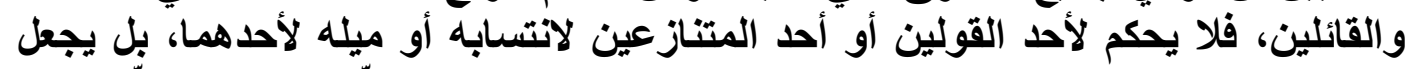

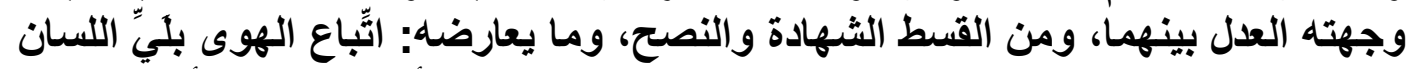

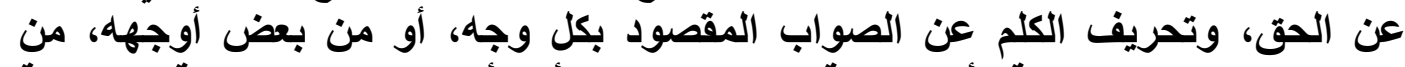

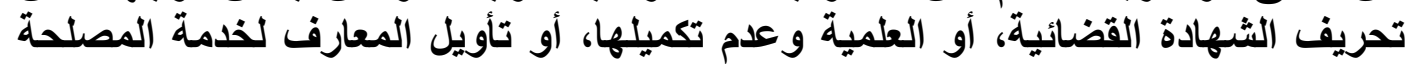

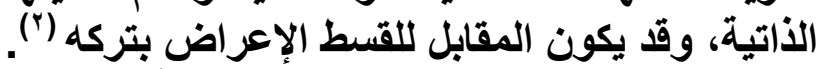

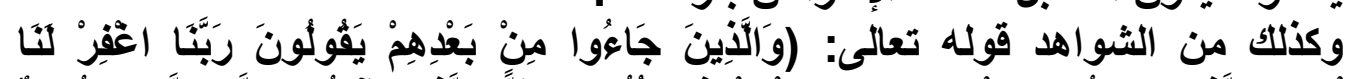

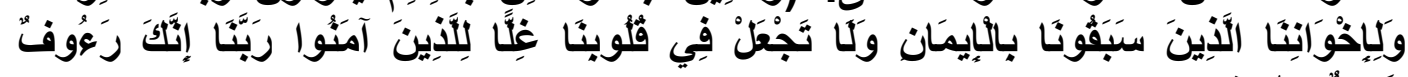

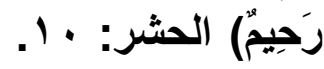

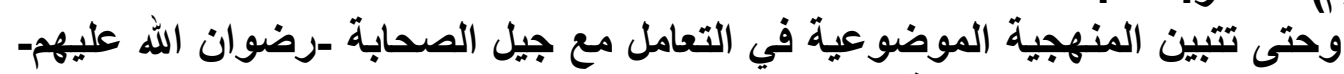
لا بل من بيان لوازم الموضوعية، والقيام بالقسط، وهي كالآتي:

(1) عبدالرحمن بن صـالح عبدالله، الموضوعية في العلوم التربويسة، دار المنـارة، جدة، طا، ل • ـ ال، ص7.

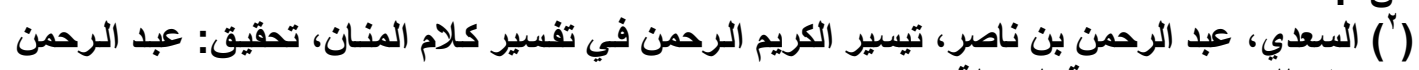

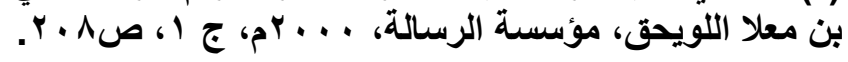
- slAr - 
أولاً: الإمساك عما شجر بينهم، فسيرة رسول الله وسير صحابته كلها فائدة وهي

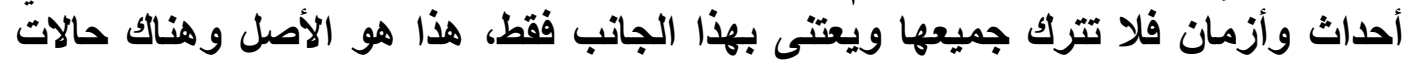

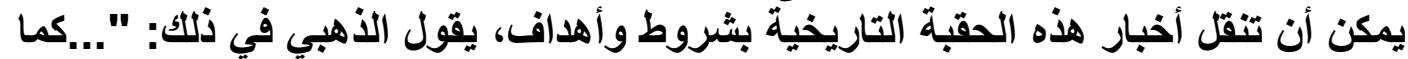

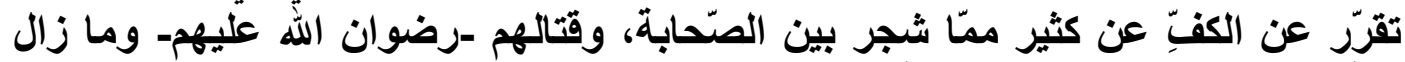

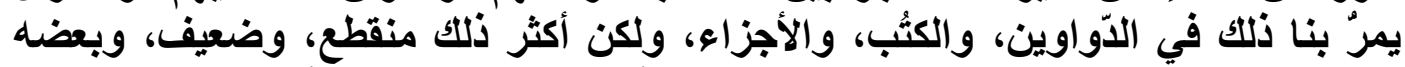

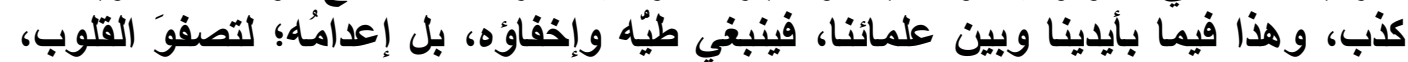

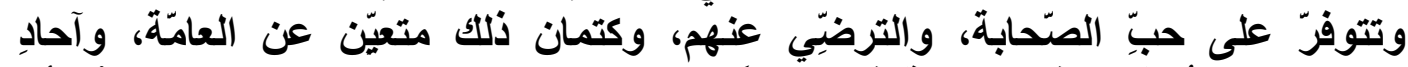

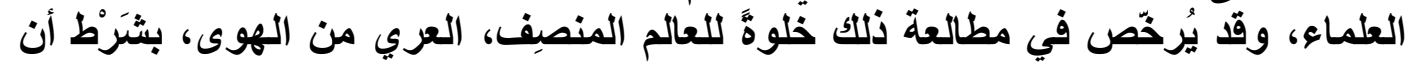

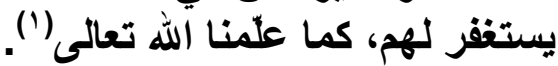

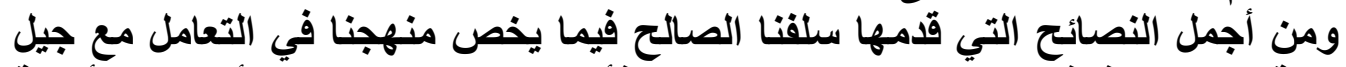

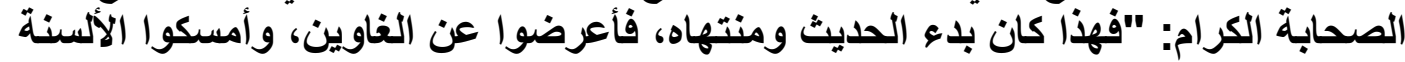

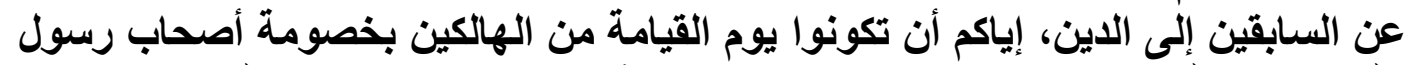

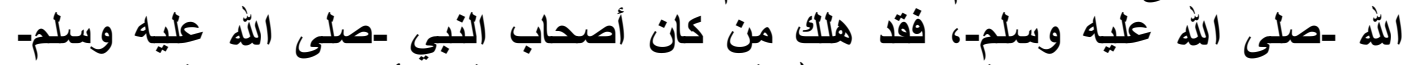

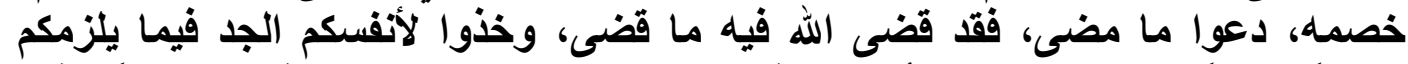

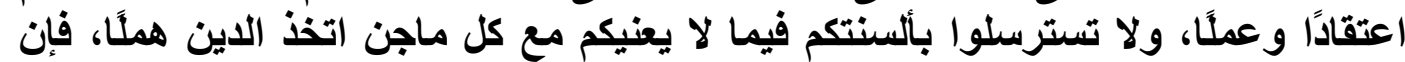

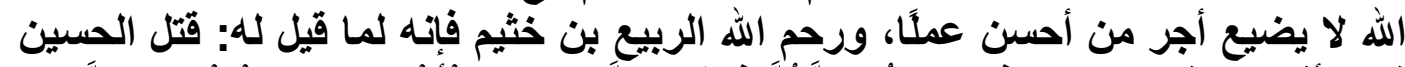

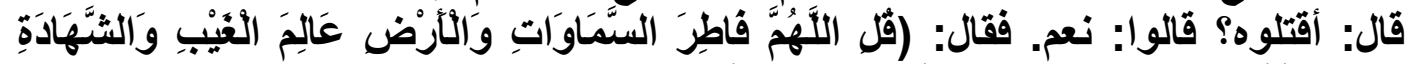

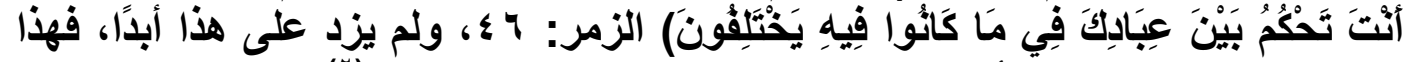

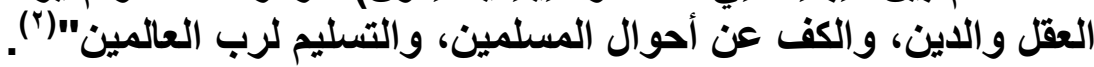

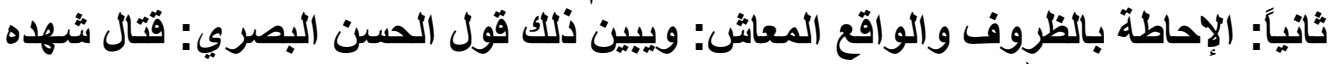

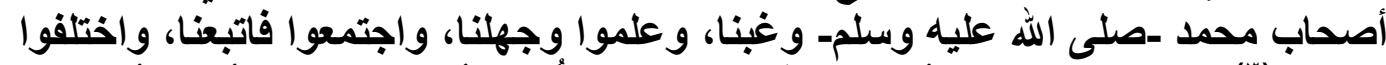

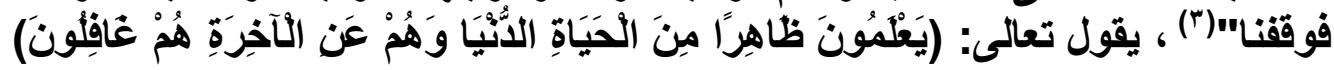

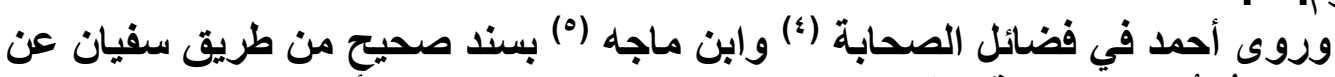

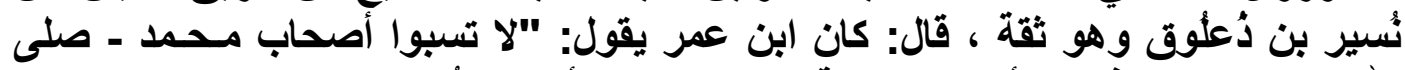

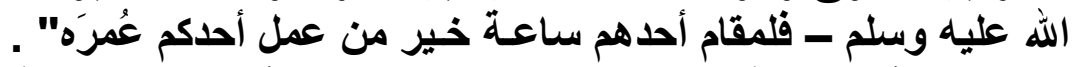

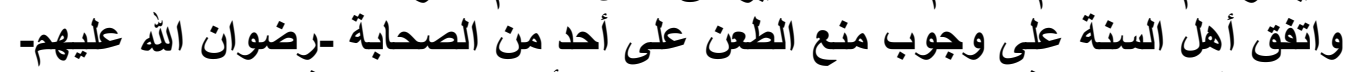

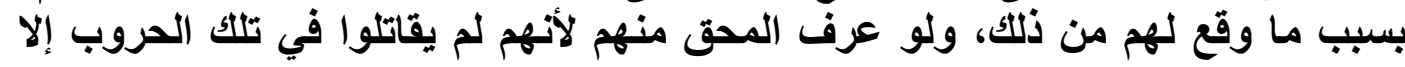

(') الذهبي، شمس الدين أبو عبد الله محمد بن أحمد بن عثمـان، سبر أعلام النبلاء، تحقيق: الأرنـاؤوط،

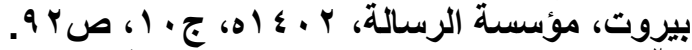

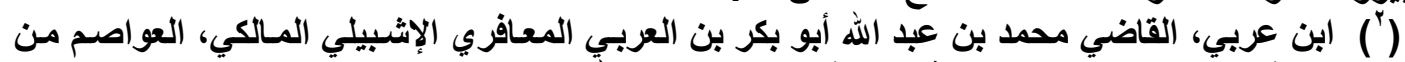

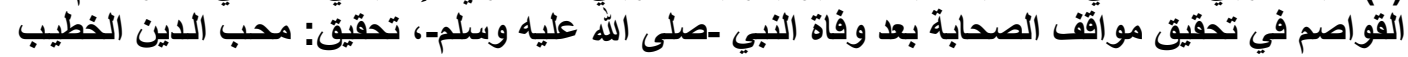

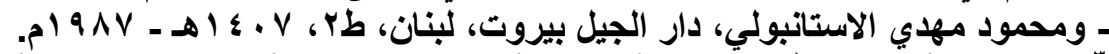

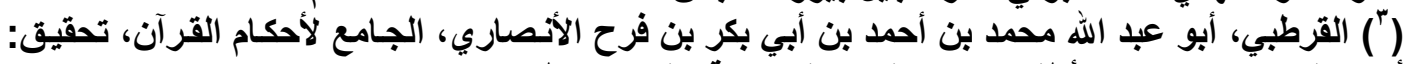

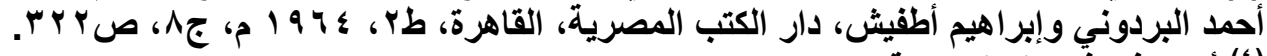

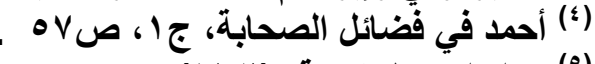


عن اجتهاد وقد عفا الله تعالى عن المخطئ في الاجتهاد ، بل ثبت أنه يؤجر أجراً واحداً ،

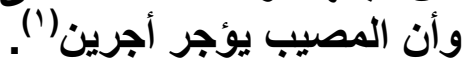

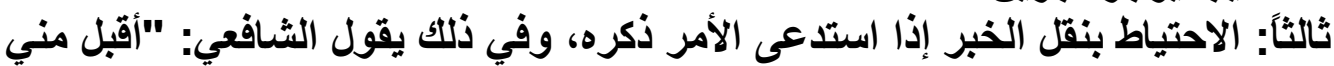

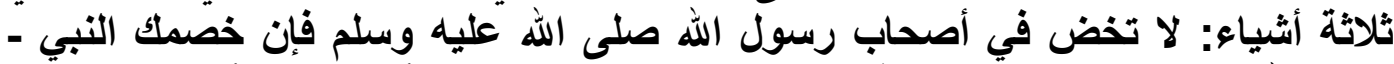

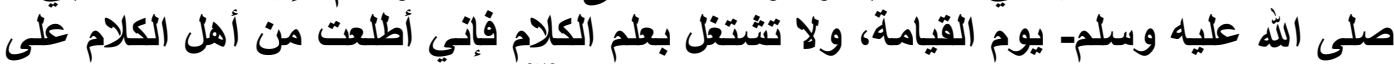

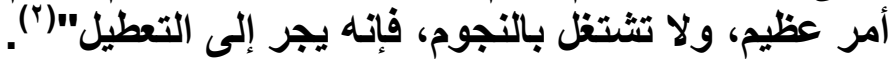

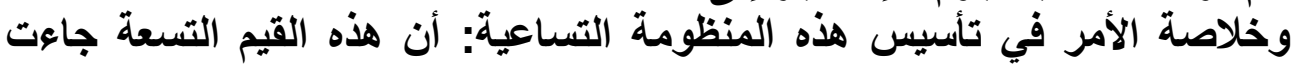

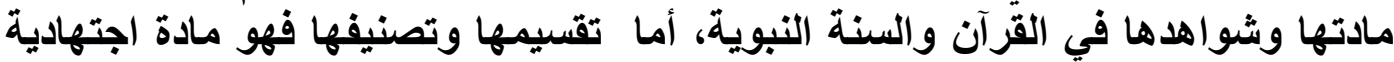

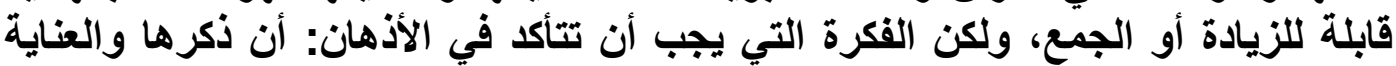

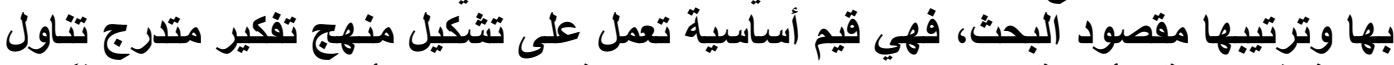

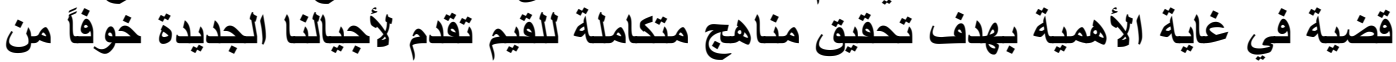
وقوعهم ضحية الجهل والتضليل. 


\section{المبمث الثالث}

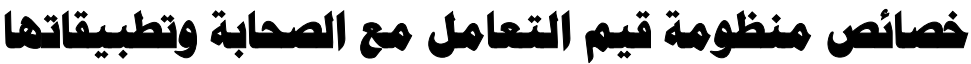

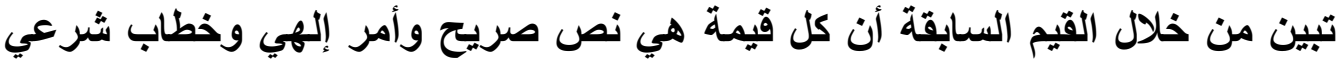

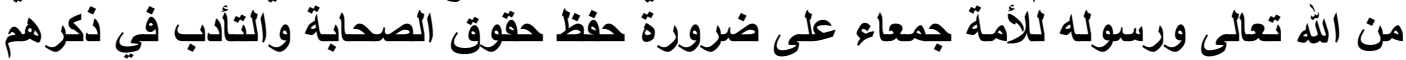
والاعتراف بفضلهم وإلزامية حبهم والدعاء لهم والترفع عن الإساءة أو التشكيك التهائ أو الطعن

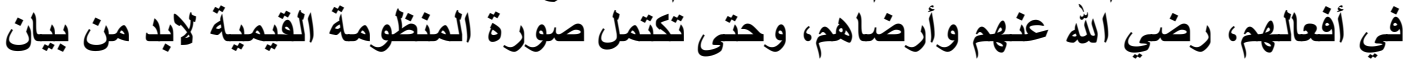
خصائصها وتطبيقاتها عند السلف الصالح ودور المناهج التربوية المعاصرة في في غرسها.

$$
\text { المطll }
$$

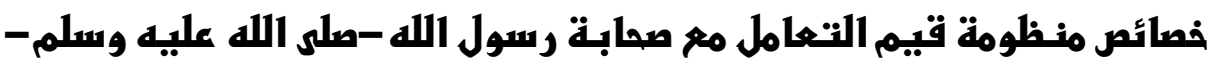

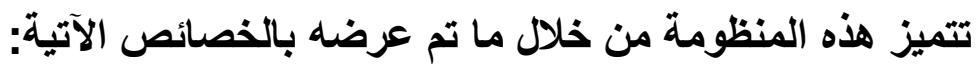

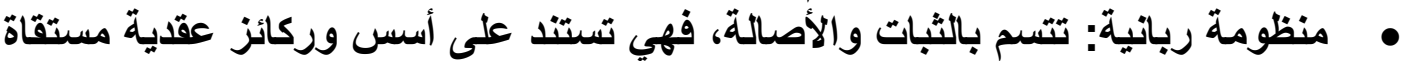

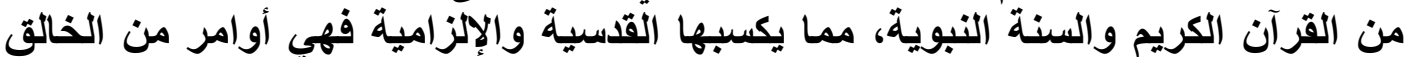

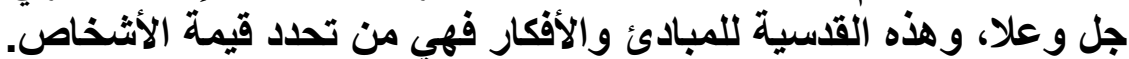

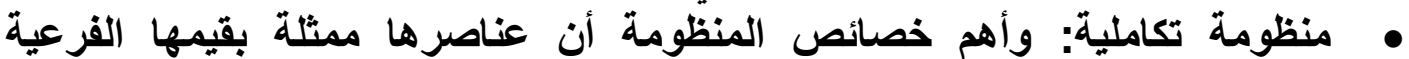

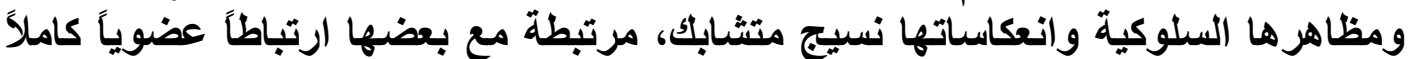

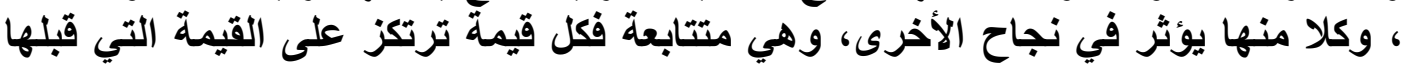

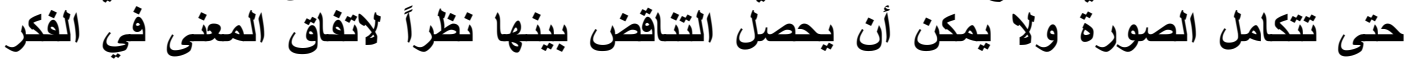
و السلوك. • منظومة واقعية: تتعامل مع الأفراد والجماعات بواقعهم المعاش، فتراعي التفاوت في

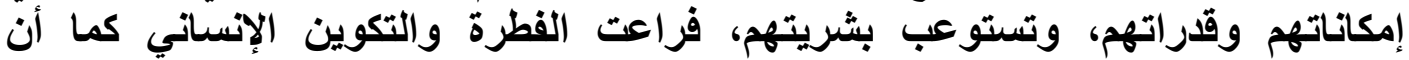

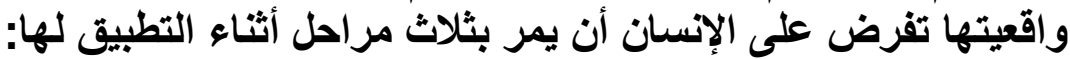

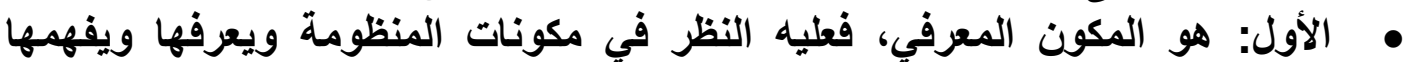
• ويؤمن بها: الثاني: المكون الوجداني، ينبغي أن يصل إلى مرحلة الاعتزاز بالقيمة وتقديرها

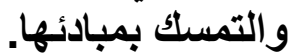
• الثالث: المكون السلوكي، وهنا ينقل ولئل الفرد ترجمة القيمة إلى ممارسة تم بناء نمط

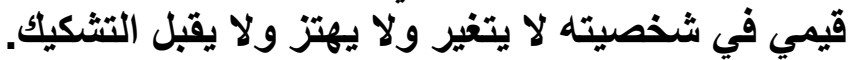

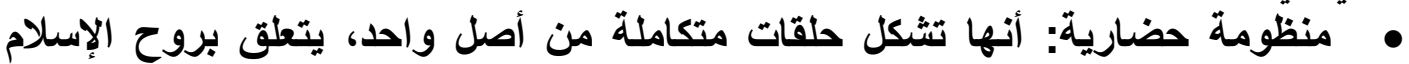

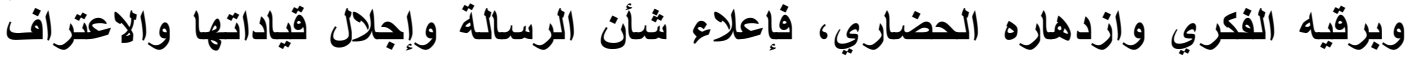

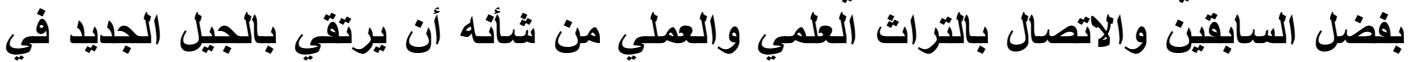

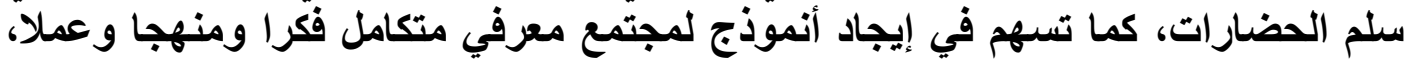

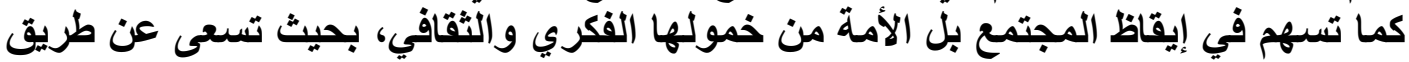

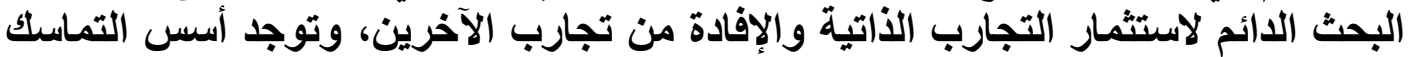
والتكافل بين أفراد المجتمع . 
• منظومة توجيهية: فقيمها عناصر موجهة للفكر والسلوك، إذ تعطي منهجية مترابطة

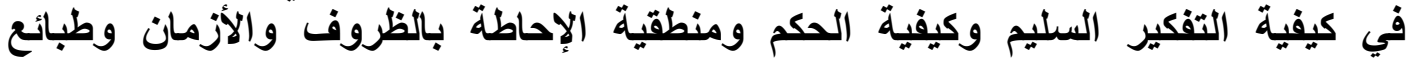

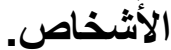

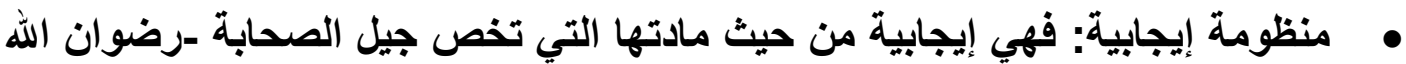

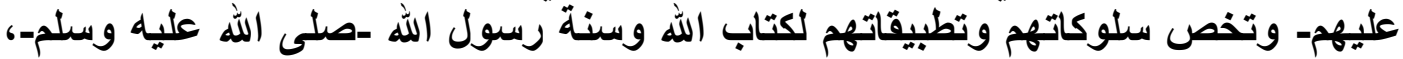

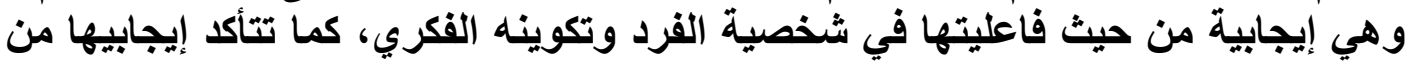

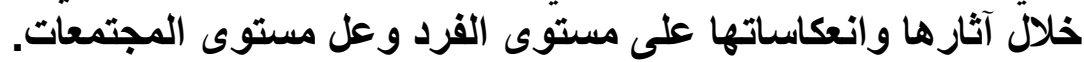

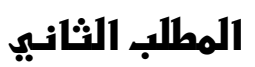
تطبيقة السلف الصالح وو عيهم لمنظومة قيم التعامل مع صحابة رسول الله -صلى 1له

\section{عليه وسلم في مؤلفاتهم}

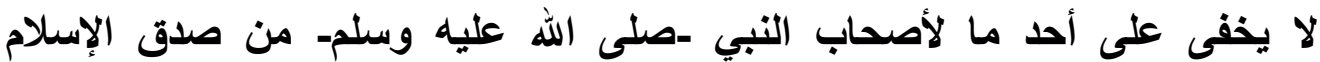

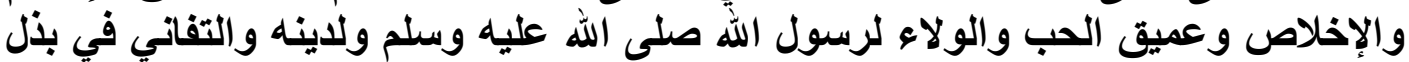

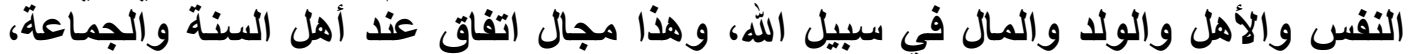

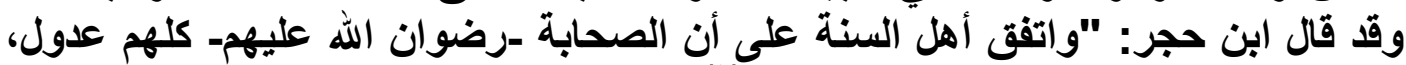

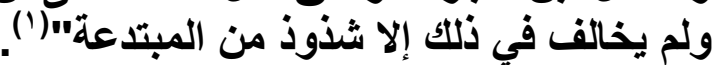

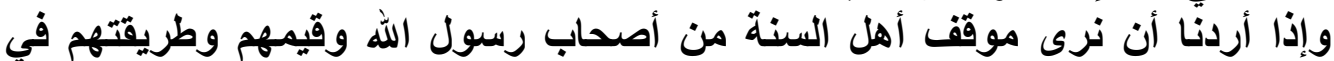

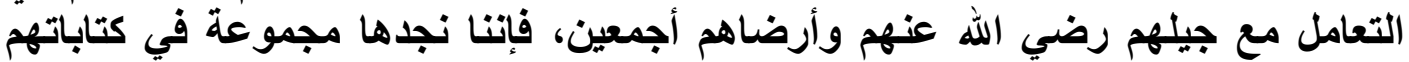

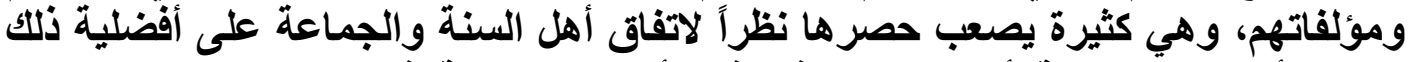

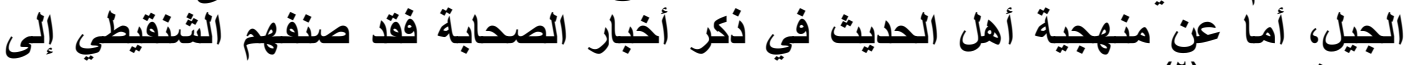

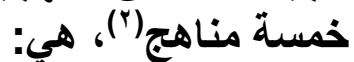

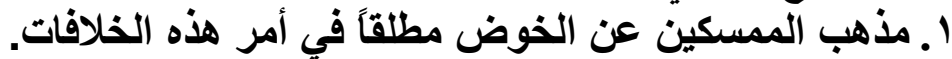

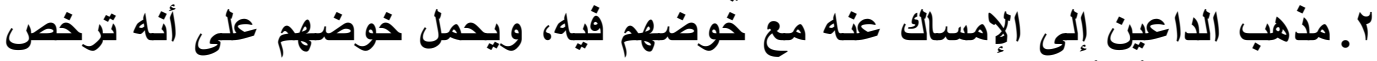

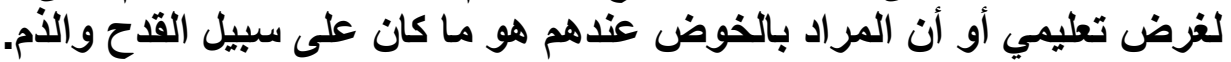

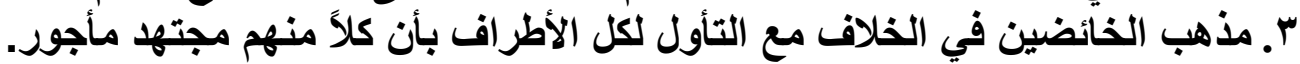

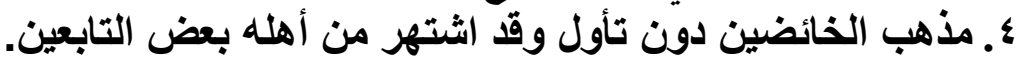

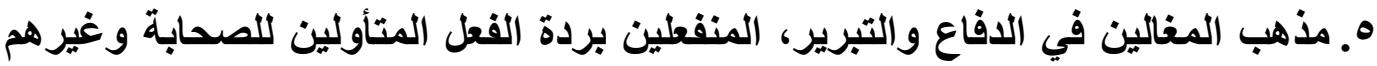
غير أن تطبيقات السلف الصالح للقيم الواجب اتباعها عند التعامل مع جيل صحابة

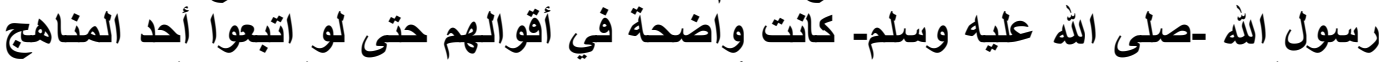

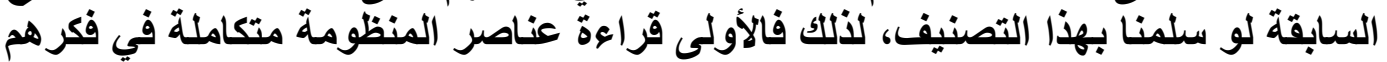

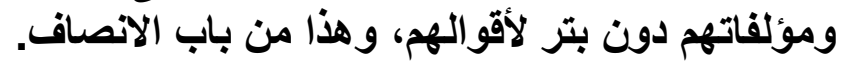

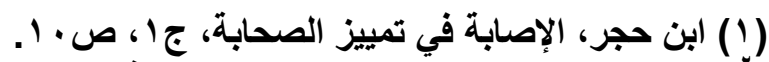

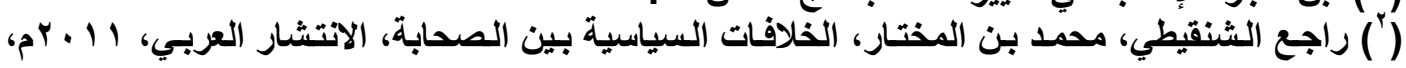


وحتى يتجب البحث الإطالة سيتم الاقتصار على نماذج محددة منتقاة من مناهج

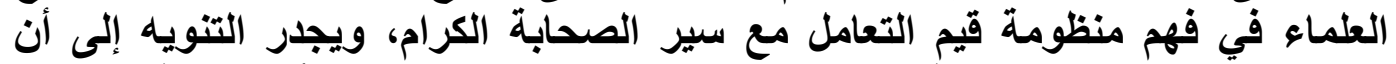

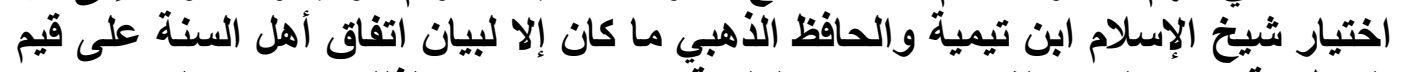

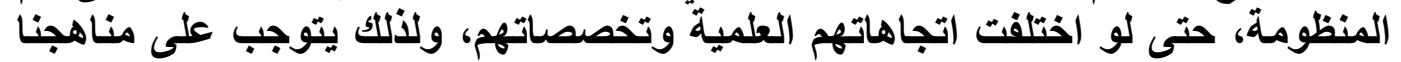

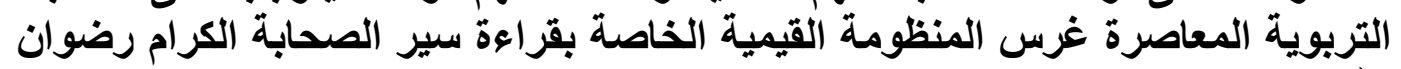

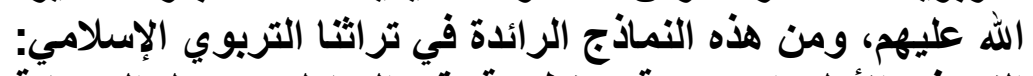

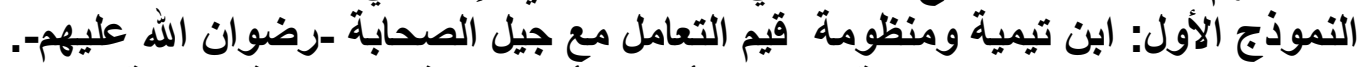

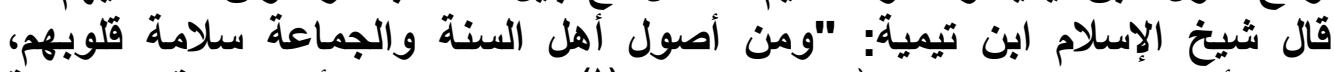

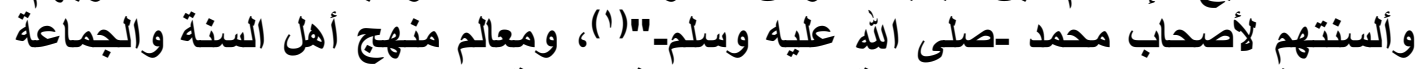

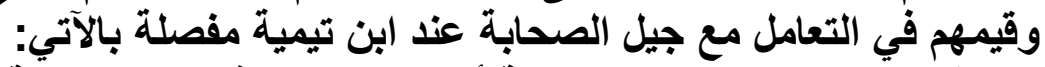

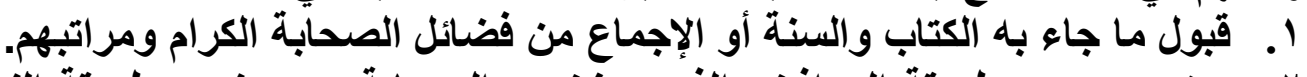

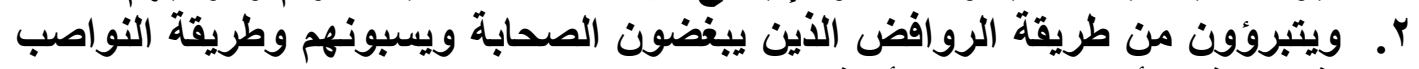

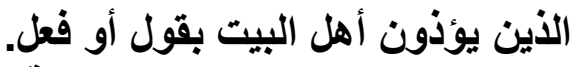
r.

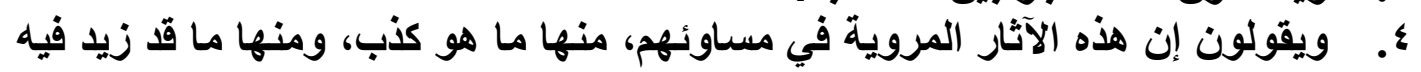
ونقص، وغيّر عن وجهه. •. أما الصحيح من تلك الآثار فهم فيه معذورون: إما مجتهدون مصيبون، وإما مجتهدون مخطئون. 7 . . . وهم مع ذلك لا يعتقدون أن كل واحد من الصحابة معصوم من كبائر الإثم وصغائره،

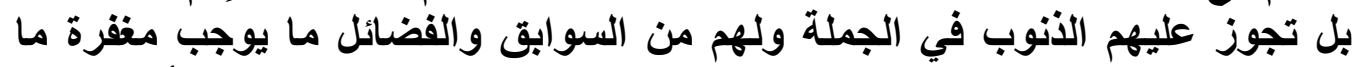

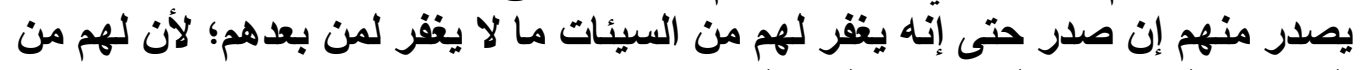

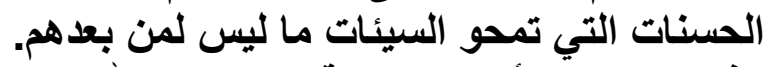

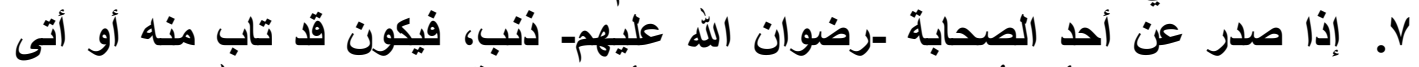

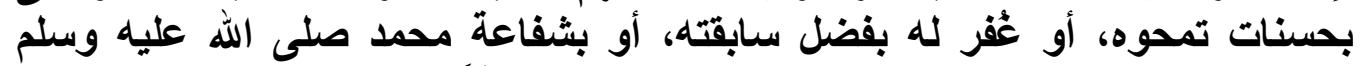

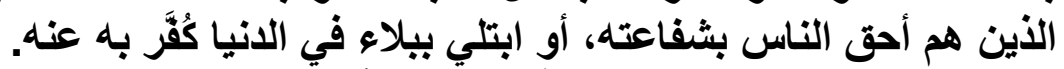

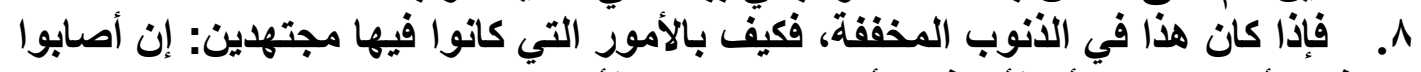

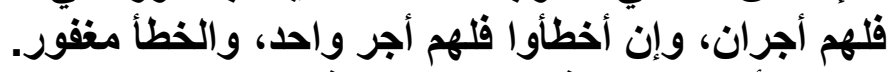

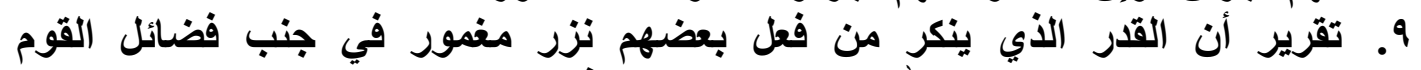

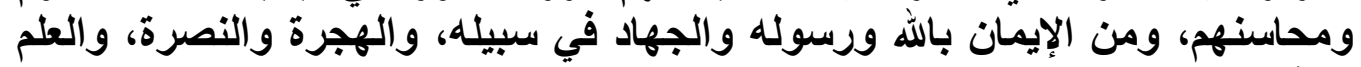

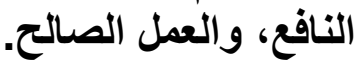

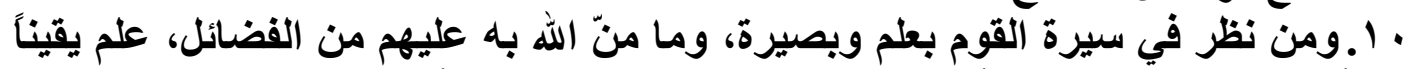

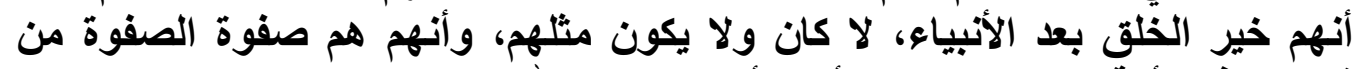
قرون هذه الأمة، التي هي خير الأمم وأكرمها ولاع، على الله.

(') ابن تيمية، أحمد بن عبد الحليم، العقيدة الواسطية، تحقيق: علوي عبد المحسن السقاف، مؤسسة

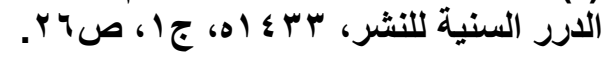


ويلحظ أن ابن تيمية بأ بتقريز الفضائل وانتهى بها كذلك، وما ذلك إلا لأن القيمة

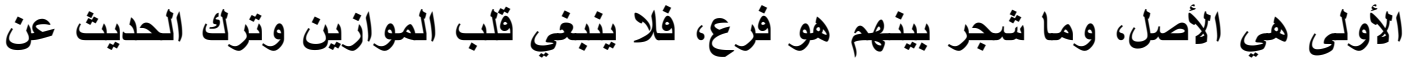

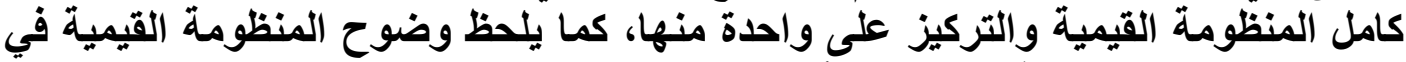

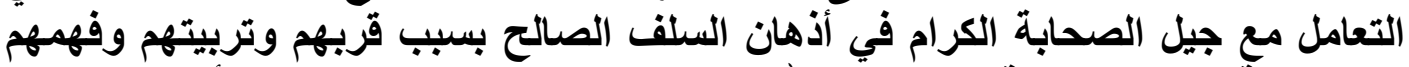

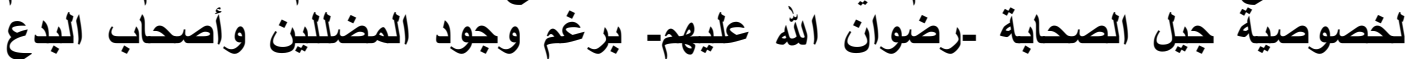

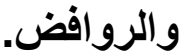
وقد تحدث ابن تيمية وطبق في كتبه ومؤلفاته منهجه ومنهج السلف عامة في ذكر والفر

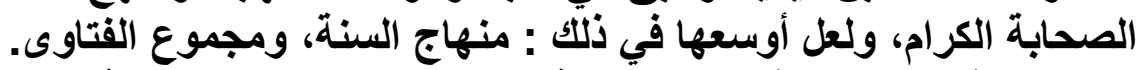

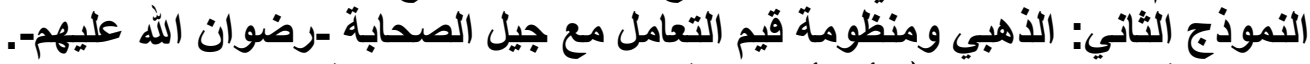

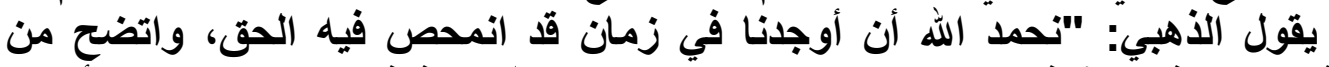

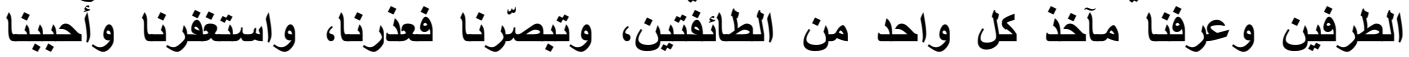

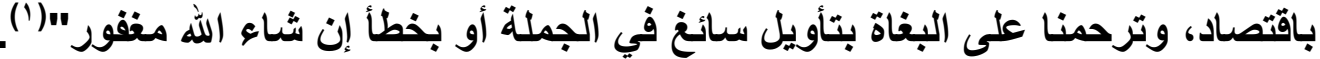

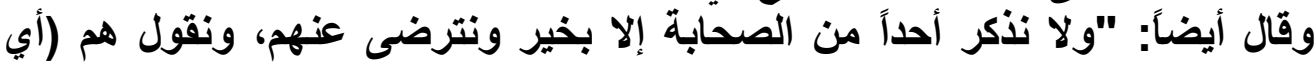

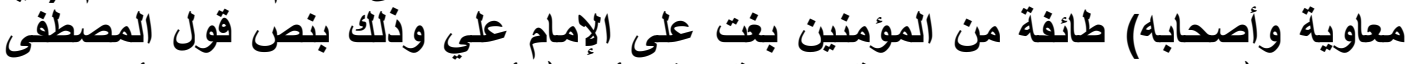

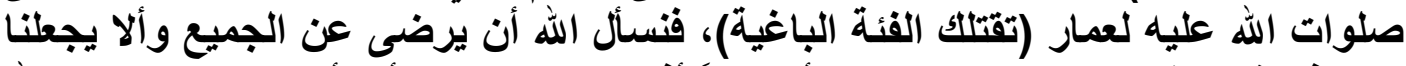

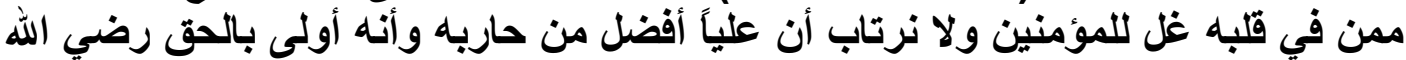

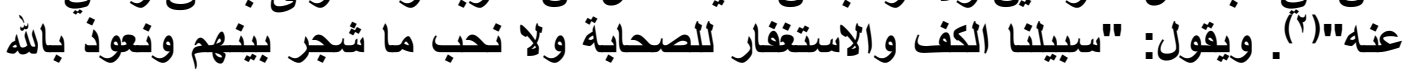
منه" (ب) (")

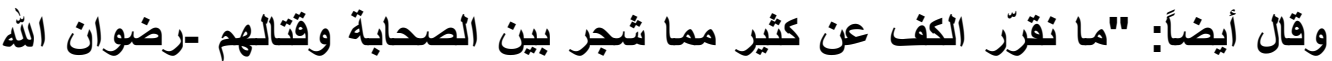

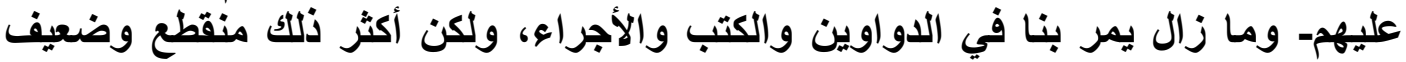

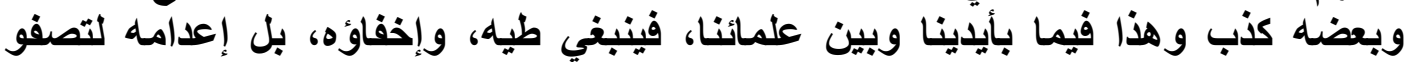

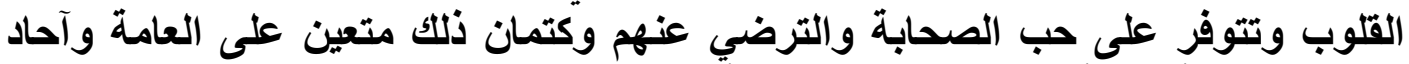

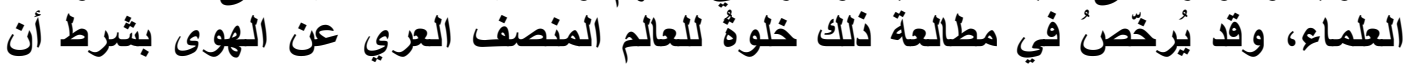

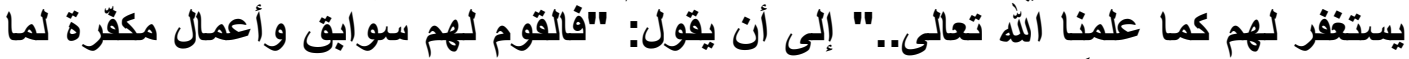

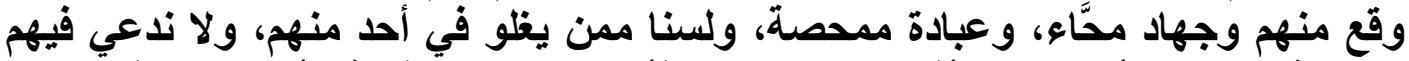

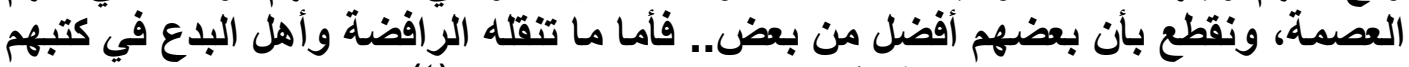

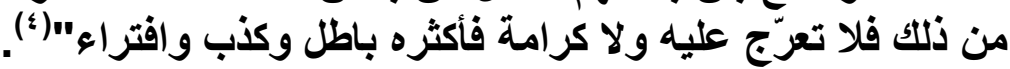

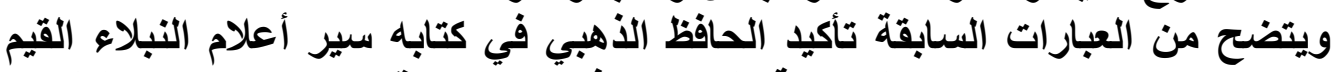

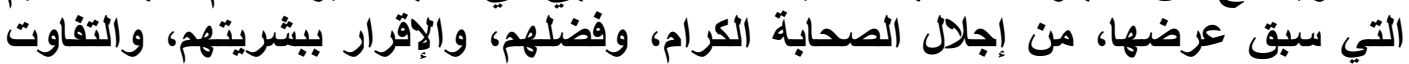

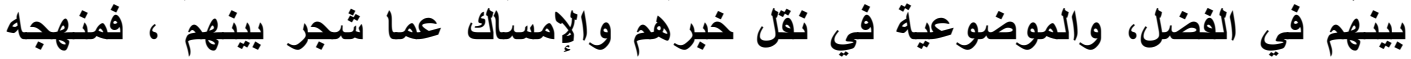

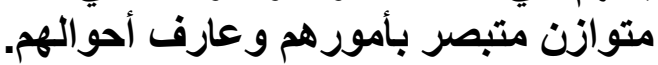


كاتت هذه بعض النماذج التي يصعب حصرها وما كان اختيارها إلا لبيان اتفاق أهل

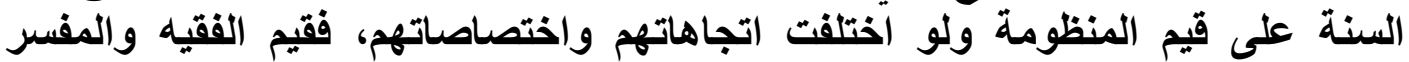

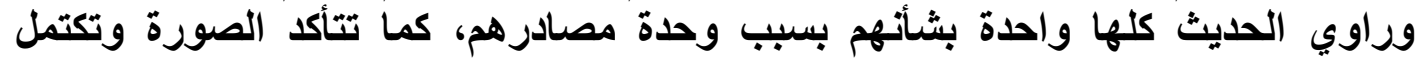

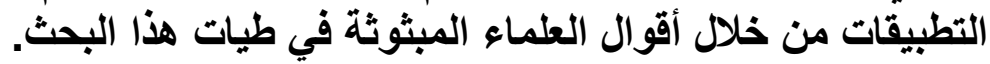

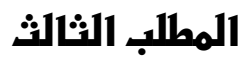

دور المناهج التربوبة المعاصرة في غر سر منظومة قبيم التنعامل مه الصصابة الكرام

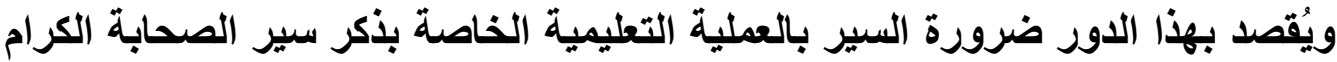

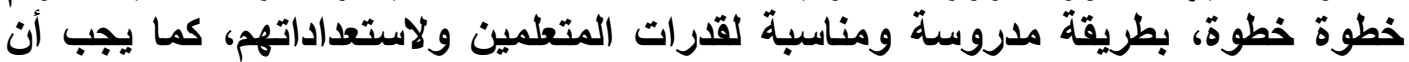

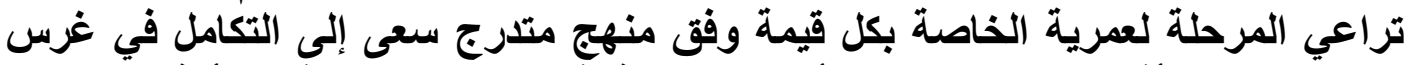

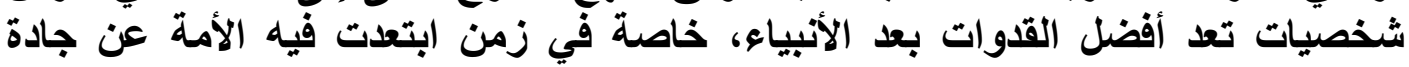

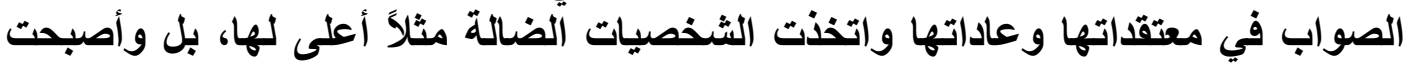
تطعن في قدوتها وأسس تقدمبها.

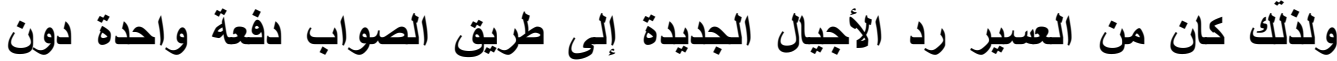

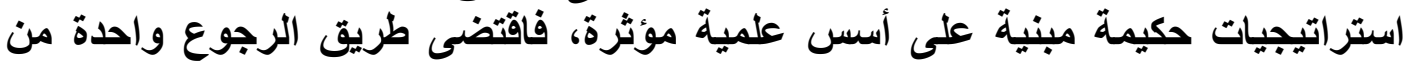

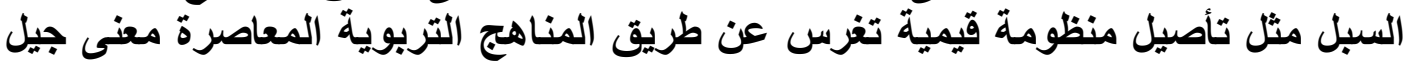

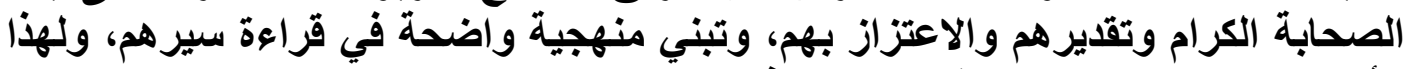

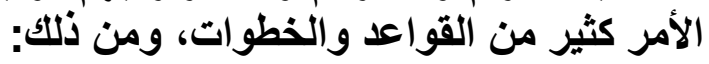

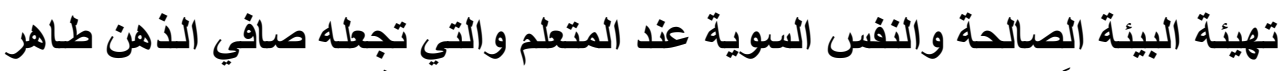

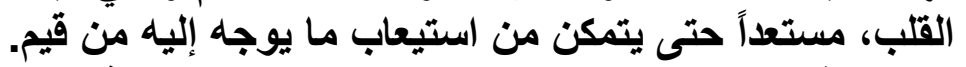

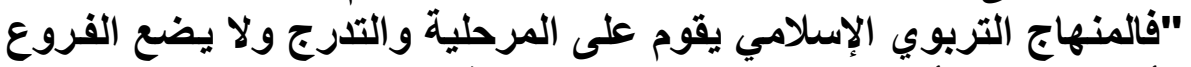

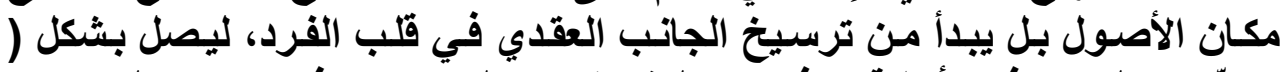

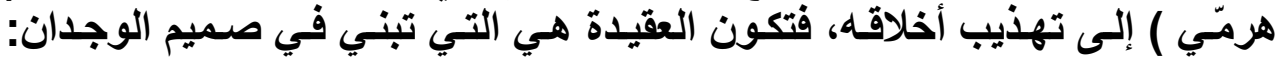

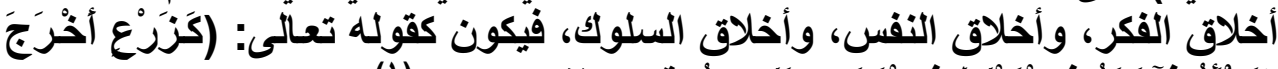

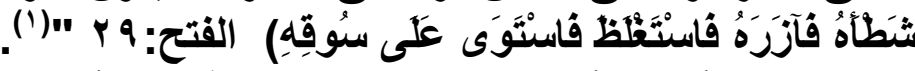

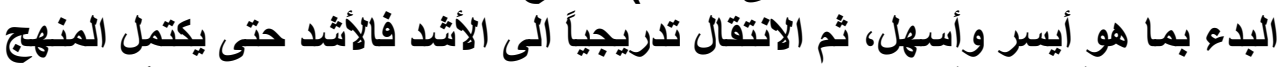

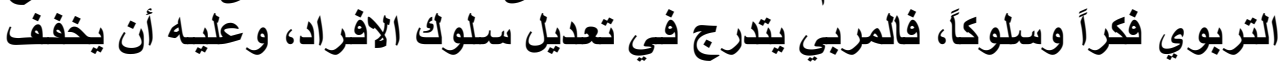

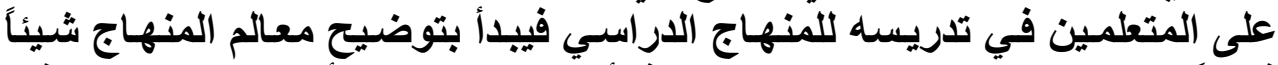

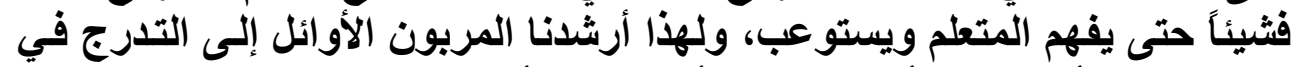

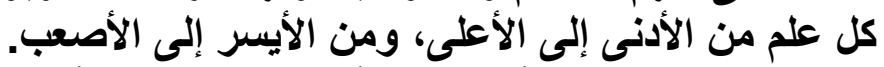

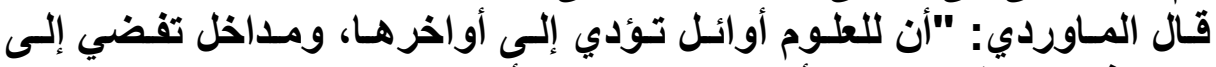

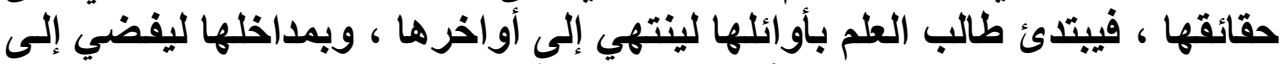

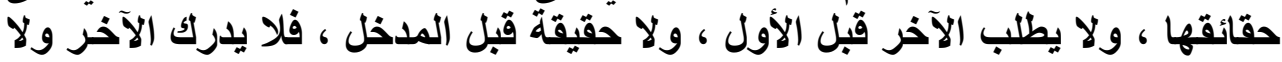

(') بلدري، محمد محمد، الأمسة الإسـلامية مـن التبعية إلى الريـادة، معـالم الأحياء الحضاري الإسـلامي،

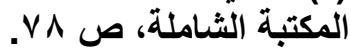


يعرف الحقيقة ، لأن البنـاء على غير أسساس لا يبني ، والثمر من غير غرس لا

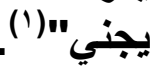

ويوضـح ابن خلدون الطريق فيقول: "اعلـم أن تلقين العلوم للمتعلمين إنمـا

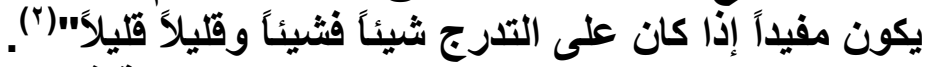

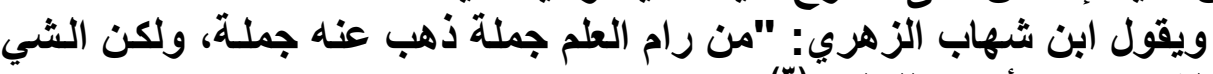

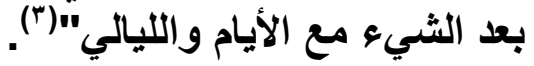

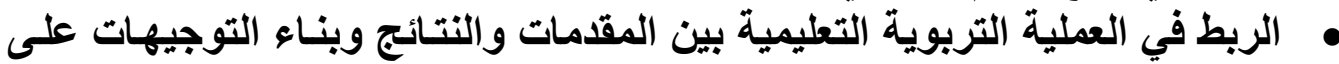

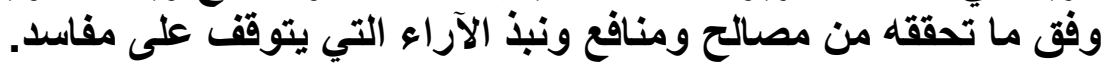




\section{لخاتمة}

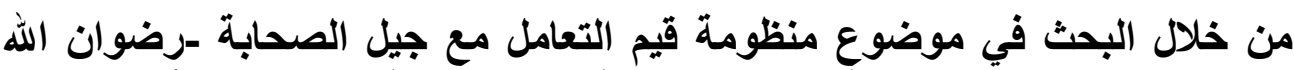

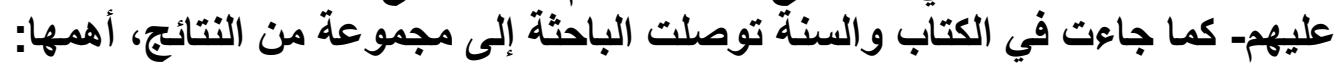

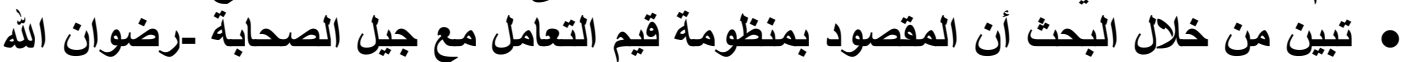

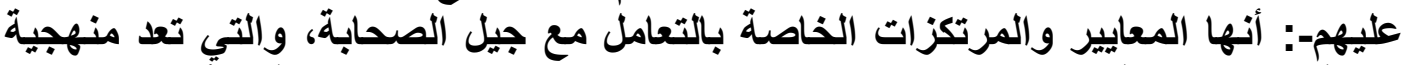

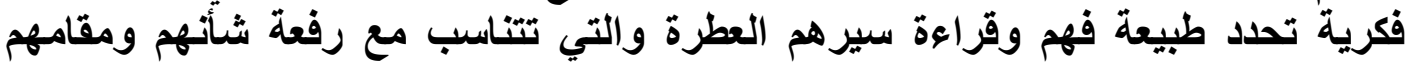

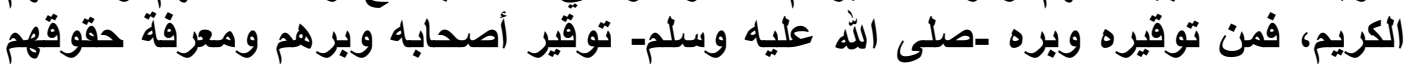

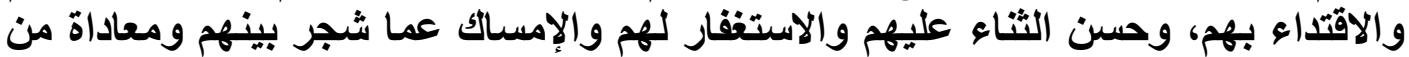

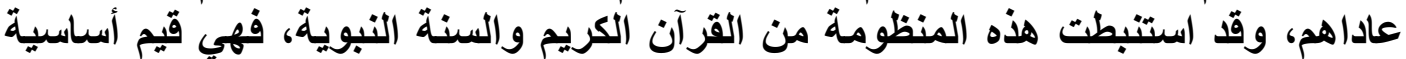

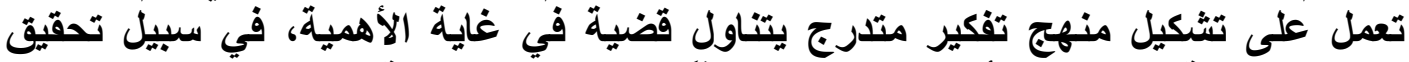

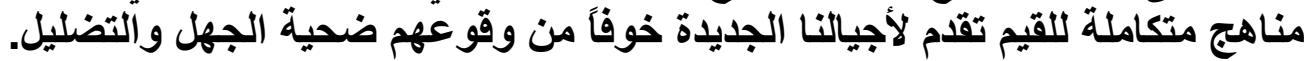

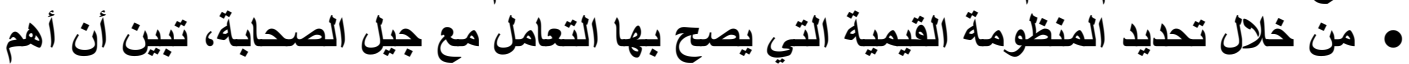

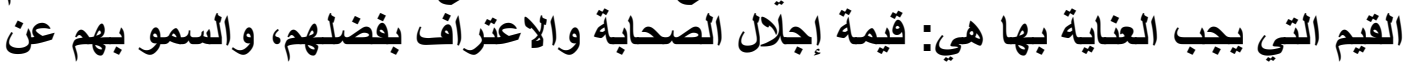

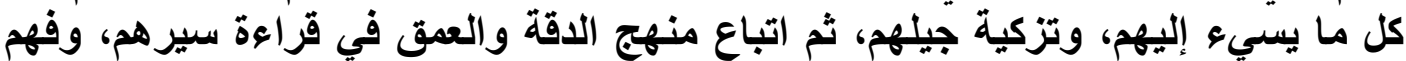

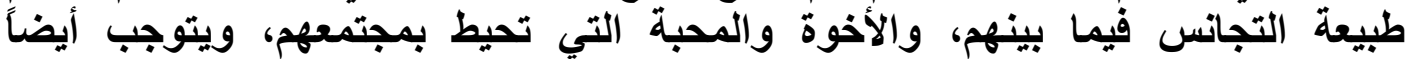

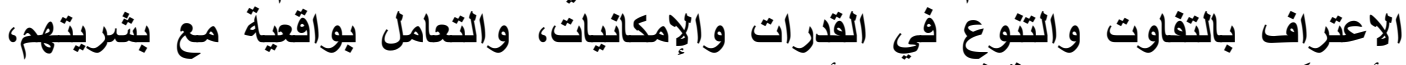

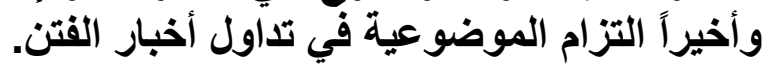

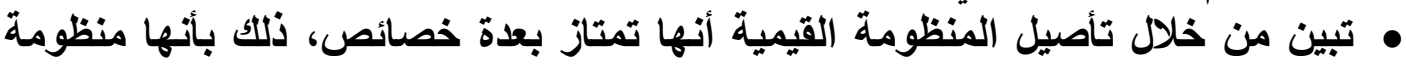

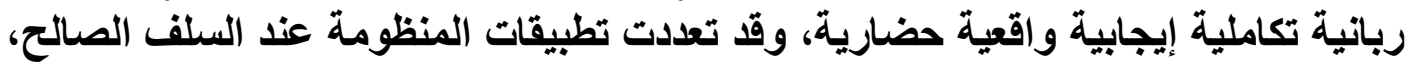

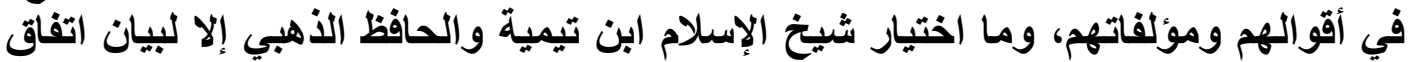

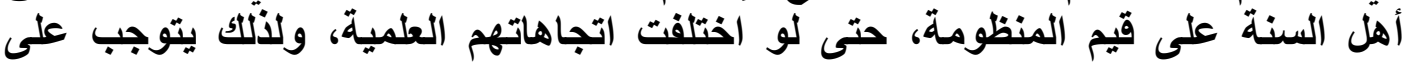

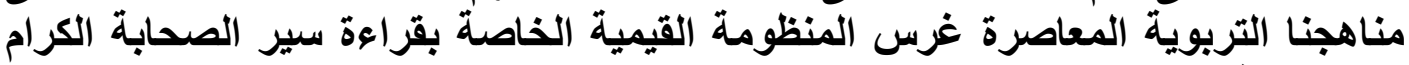
رضوان الله عليهم.

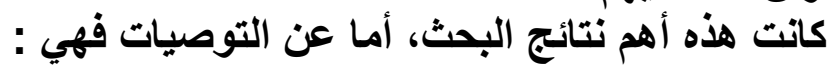

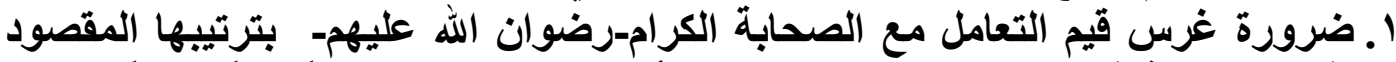

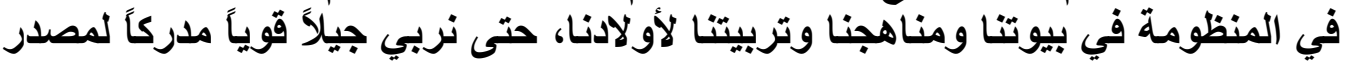

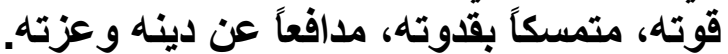

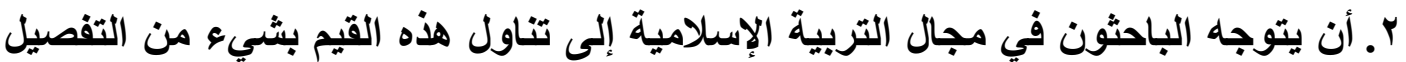

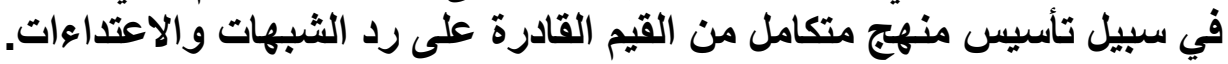


المراجع والمصادر:

• أحمد، إسماعيل حسنين، غرس والمعادئ القيم الإسلامية في نفوس الناشئة، الدراسات الإسلامية،

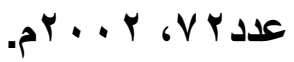

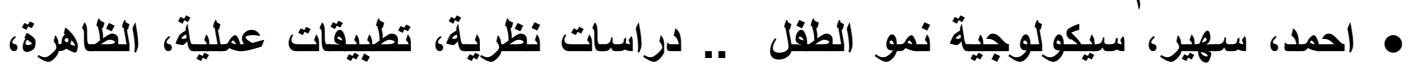

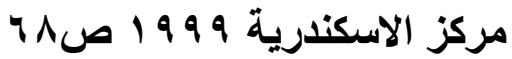

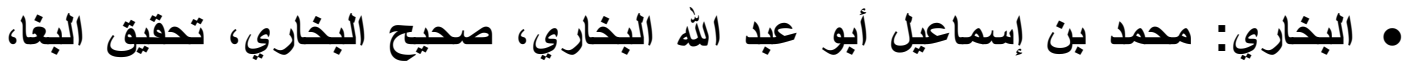

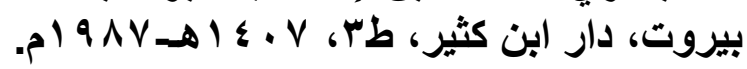

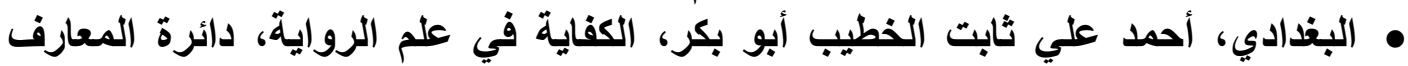
العثمانية،

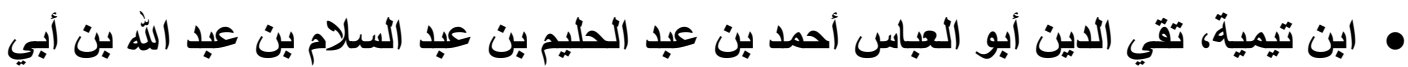

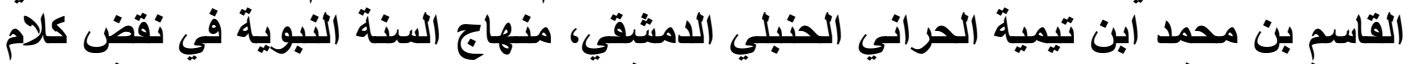

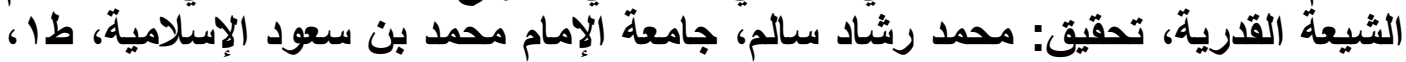

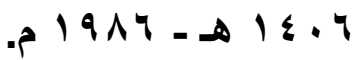
• ابن تيمية، تقي الاين أحمد بن عبد الحليم، العقيدة الواسطية، تحقيق: علوي عبد

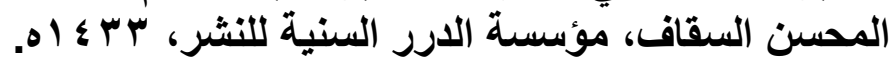

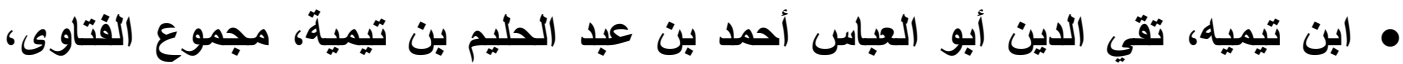

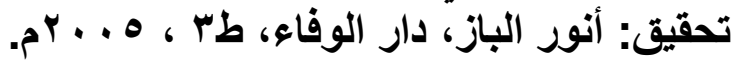

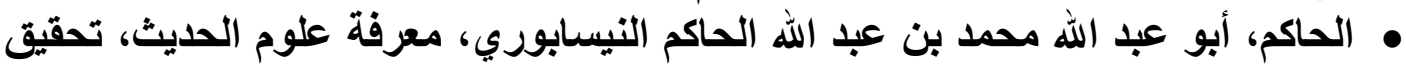

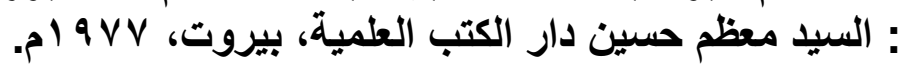

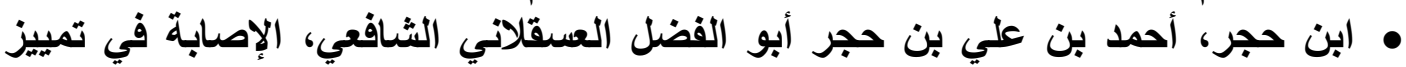

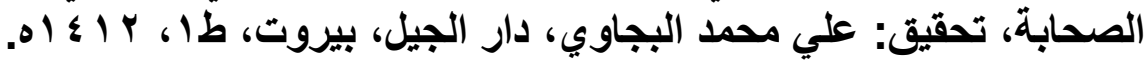

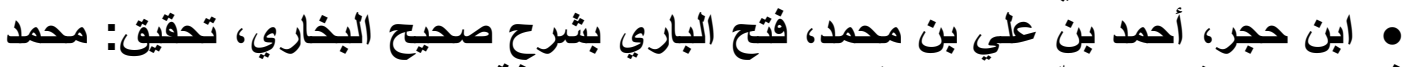

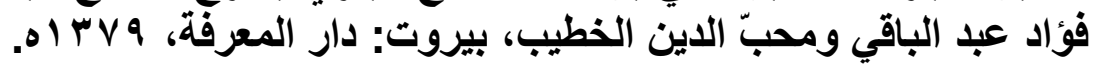

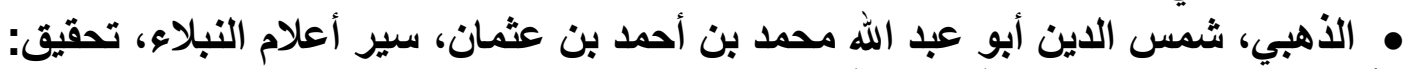

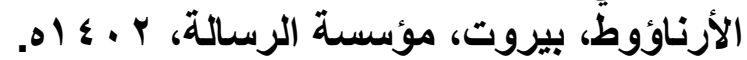

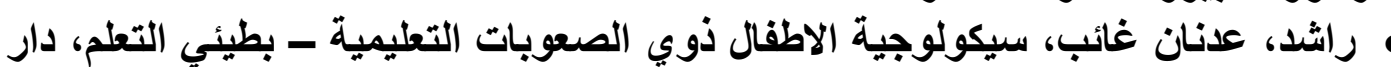

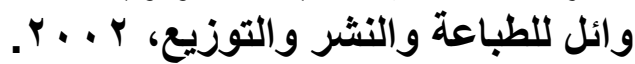

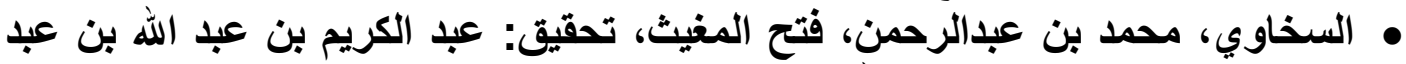

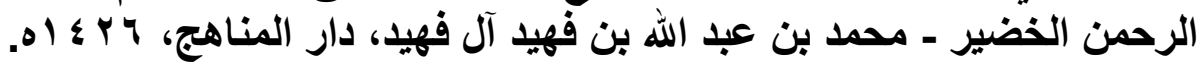

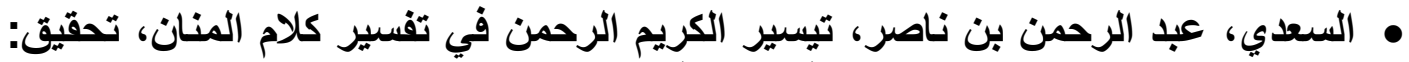

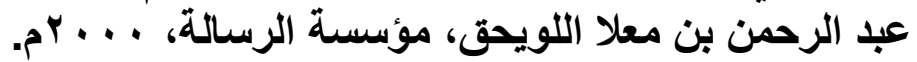

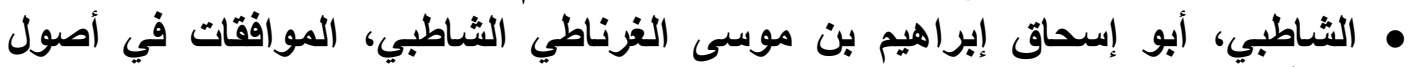

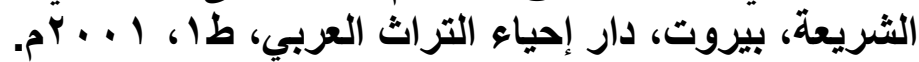
• الشنقيطي، محمد بن المختار، الخلاقًات السياسية بين الصحابة الصابة، الانتشار العربي، r. 11 


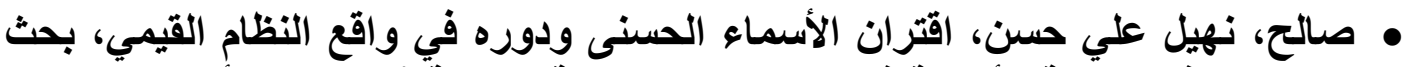

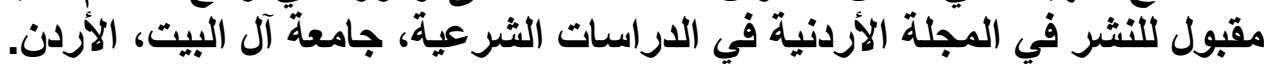

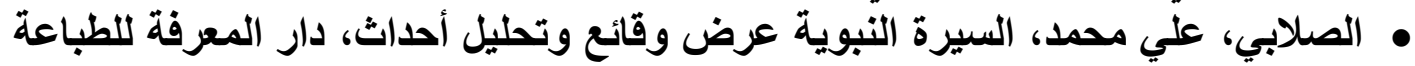

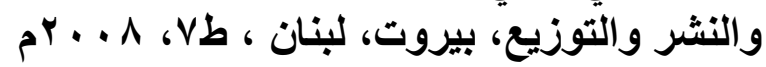

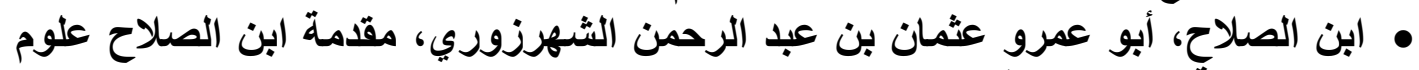

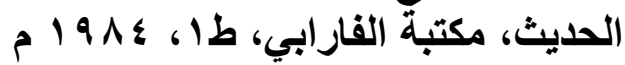

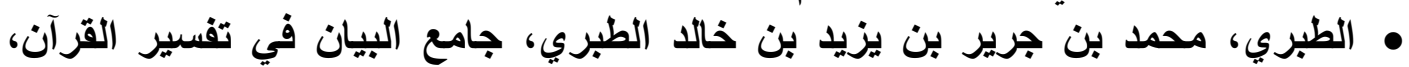

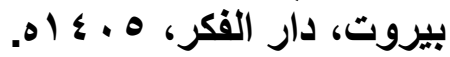
• عبدالله، عبدالرحمن بن صالح، الموضوعية في العلوم التربوية، دار المنارة، جدة، طا، $.1 \leqslant \cdot V$ • عبد المجيد مسعود، القيم الإسلامية التربوية والمجتمع المعاصر، كتاب الأمة. وزارة

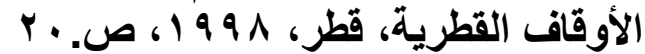

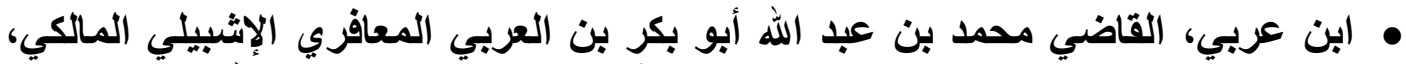

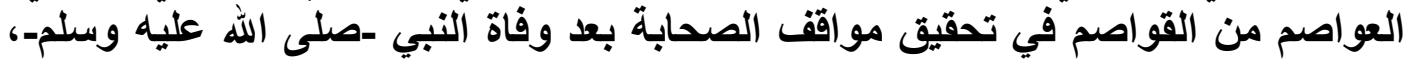

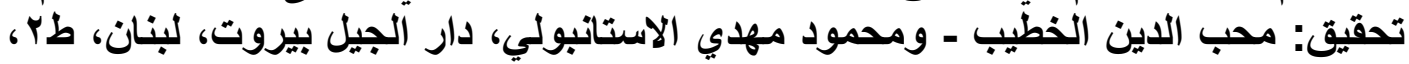

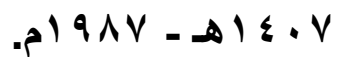

• غيث، عاطف، قاموس علم الاجتماع، الإسكندرية، دار المعرفة الجامعية، و9 99 أم.

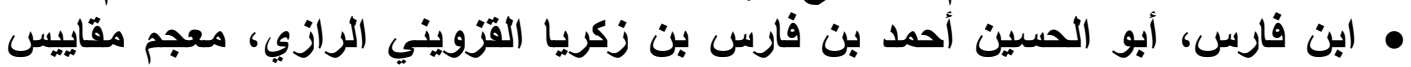

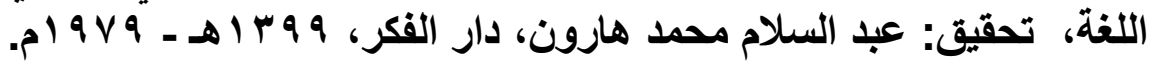

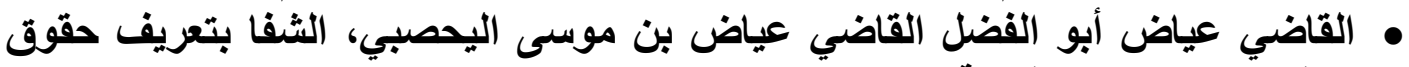

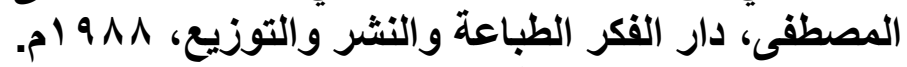

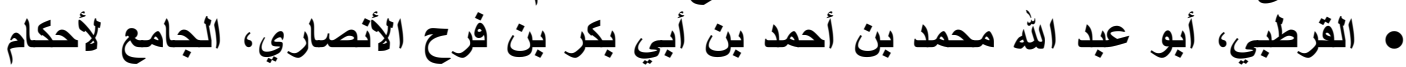

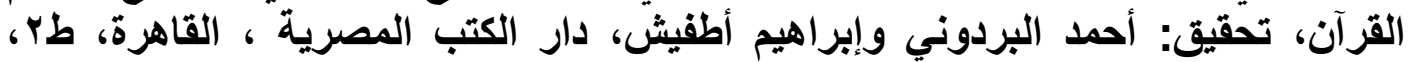
( )

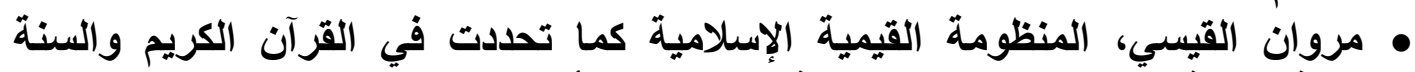

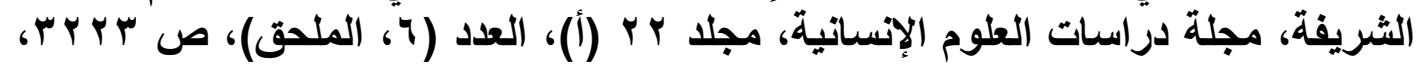

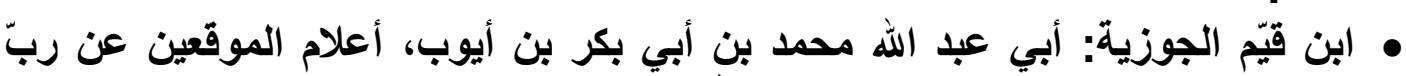

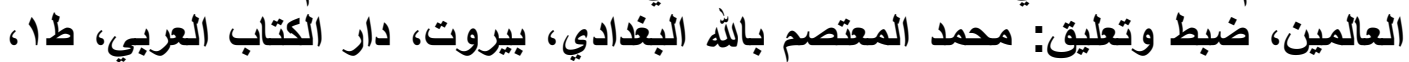
• ابن قيم الجوزية، محمد بن أبي بكر أيوب الزرعي أبو عبد الله، التبيان في أقسام

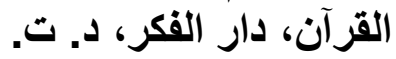
• ابن قيم الجوزية، محمد بن أبي بكر أيوب الزران، أبرأ أبو عبد الله، التبيان في أقسام القزآن، دار الفكر، د. ت. ت. • الكتاني، محمد، منظومة دانة القيم المرجعية في الإسلام، المغرب، دار أبي رقراق للطباعة

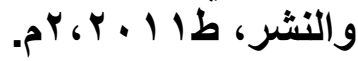


• ابن كثير، إسماعيل بن عمر بن كثير القرشي الدمشقي، تفسير ابن كثير، دار طيبة،

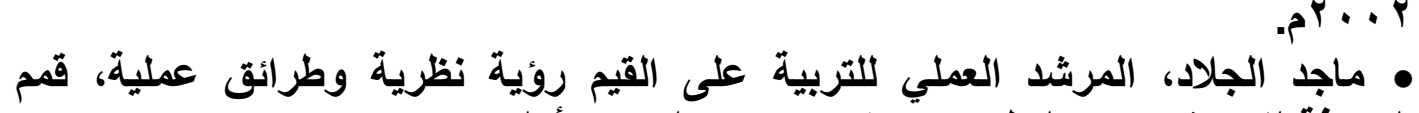

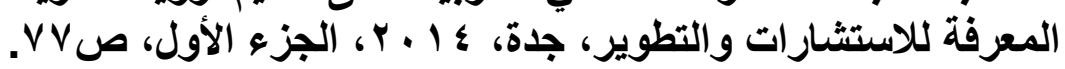

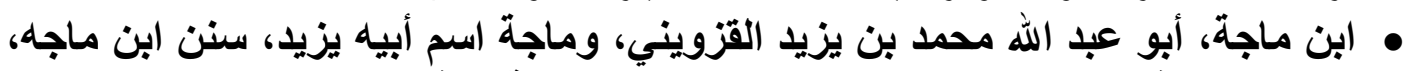

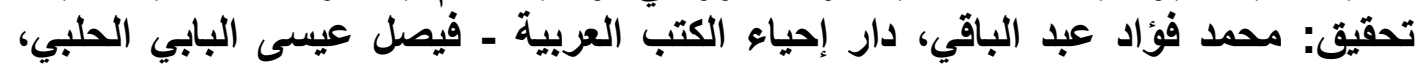

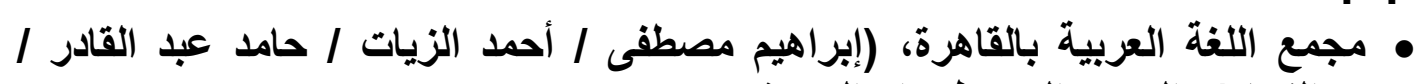

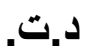

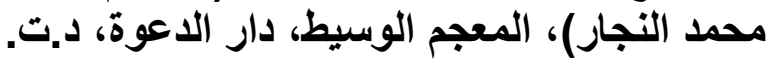
• مسلم: مسلم بن الحجاج، صحيح مسلم، تحقيق: محمد فؤاد عبد الباقي، بيروت، دار

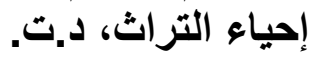
• إبن منظور، محمد بن مكرم بن على، أبر، أبراء الفضل، جمال الدين ابن منظور الأنصاري،

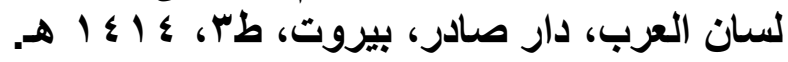
• انظر تسنيم نور الدين المهيدات، نظرية القير التيم التعليمية في الفكر الإسلامي وتطبيقاتها

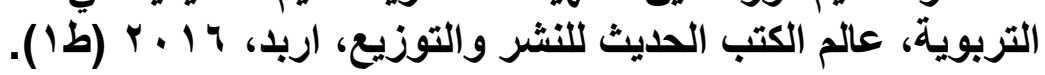

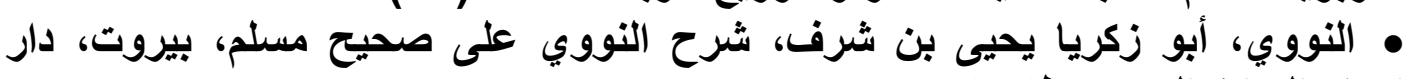

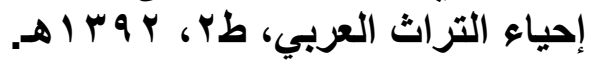

